\title{
Conquering the Cultural Frontier: The New Subjectivism of the Supreme Court in Indian Law
}

\author{
David H. Getches $\dagger$
}

For a century and a half, the Supreme Court was faithful to a set of foundation principles respecting Indian tribal sovereignty. Though the United States can abrogate tribal powers and rights, it can only do so by legislation. Accordingly, the Court has protected reservations as enclaves for Indian self-government, preventing states from enforcing their laws and taxes, and holding that even federal laws could not be applied to Indians without congressional permission. Recently, however, the Court has assumed the job it formerly conceded to Congress, considering and weighing cases to reach results comporting with the Justices' subjective notions of what the Indian jurisdictional situation ought to be. This new subjectivist approach, the author argues, severs tribal sovereignty from its historical moorings, leaving lower courts without principled, comprehensible guidance. Tribes hold distinct legal rights in treaties and other laws. They strive to perpetuate their cultures and land base through governance. But now they are left to the vicissitudes of Court majorities that depend on the perceptions of culturally alien Justices in individual cases. The author also assesses prospects for returning to foundation principles. Although most of the current Court accepts subjectivism, he concludes that a return is possible if one or more Justices assumes intellectual leadership in Indian law cases.

\section{INTRODUCTION}

The right of Indians to tribal self-government has always been vulnerable to abrogation by acts of Congress. But the courts have generally served as the conscience of federal Indian law, protecting

Copyright $@ 1996$ California Law Review, Inc.

$\dagger$ Raphael J. Moses Professor of Law, University of Colorado School of Law. The author is grateful for the careful and extensive research and editorial assistance of Bartlett Miller and Edward Kowalski, Class of 1995, University of Colorado School of Law, and for the thoughtful and critical reviews of drafts of the article by Professors Richard B. Collins and Robert A. Williams, Jr. Research into the papers of Justices Thurgood Marshall and William Brennan was possible with the cooperation of the staff of the Library of Congress Manuscript Division over several weeks. Their courtesy and diligence and the kind permission granted by Justice Brennan are warmly acknowledged. 
tribal powers and rights at least against state action, unless and until Congress clearly states a contrary intention. The Supreme Court has recently begun to depart froin this traditional standard, abandoning entrenched principles of Indian law in favor of an approach that bends tribal sovereignty to fit the Court's perceptions of non-Indian interests.

In 1941 Felix S. Cohen synthesized inore than a century of the law of tribal self-government when he wrote:

The whole course of judicial decision on the nature of Indian tribal powers is marked by adherence to three fundamental principles: (1) An Indian tribe possesses, in the first instance, all the powers of any sovereign state. (2) Conquest renders the tribe subject to the legislative power of the United States and, in substance, terminates the external powers of sovereignty of the tribe, e.g., its power to enter into treaties with foreign nations, but does not by itself affect the internal sovereignty of the tribe, i.e., its powers of local self-government. (3) These powers are subject to qualification by treaties and by express legislation of Congress, but, save as thus expressly qualified, full powers of internal sovereignty are vested in the Indian tribes and in their duly constituted organs of government. ${ }^{1}$

These foundation principles still held true when Cohen's Handbook of Federal Indian Law was revised in 1982. ${ }^{2}$ And they guided a spate of landmark cases in the "modern era" of federal Indian law that encouraged a reinvigoration of tribal governments throughout the country. ${ }^{3}$ During this period, tribes gained political influence and economic security as Congress and the executive also generally promoted a policy of tribal self-determination.

To the extent that it was defined by a trend in Supreme Court jurisprudence, however, the modern era has ended. Over the last fifteen years, partly as a result of tribes' broader assertions of power over reservation activity, non-Indian interests have been allowed to play a greater

1. Felix S. Cohen, Handbook of Federal Indian Law 123 (1941) [hereinafter Cohen (1941)].

2. Cohen's formulation was reiterated without substantial editing. FELIX S. CoHEN, HANDBOOK OF FEDERAL INDIAN LAW 241-42 (Rennard Strickland ed., 1982) [hereinafter CoheN (1982)].

3. Charles Wilkinson called the period following the decision of Williams v. Lee, 358 U.S. 217 (1959), the modern era of Indian law. Charles F. WILkinson, AMERican INDIANS, Time, AND THE LAW 1 (1987). He states:

The modern cases reflect the premise that tribes should be insulated against the passage of time. Inevitably, there are some exceptions, but the mainstream of opinions has built a number of rules that prevent state powers and private rights from expanding to encroach upon tribal prerogatives except by express congressional permission.

Id. at 32. When he wrote, the Court had already begun to depart from this trend, though it was then still reasonable to isolate those departures as aberrations. 
role in Indian country jurisdictional disputes. As these disputes have reached the United States Supreme Court, several decisions have curtailed exercises of tribal governing power that cast a cultural shadow on non-Indian values, personal liberties, or property interests. The Court has become the arbiter of how much governing authority tribes may exercise, assuming a prerogative that it formerly conceded to the political branches of government. It now gauges tribal sovereignty as a function of changing conditions-demographic, social, political, and economic-and the expectations they create in the minds of affected non-Indians. In the emerging jurisprudence of Indian law, the Court arrogates to itself the role of reviewing and weighing non-Indian interests and, ultimately, of redesigning the sovereignty of Indian tribes.

This subjectivist trend in recent Indian law decisions is brought into sharp relief by previously confidential memoranda and draft opinions discovered in the files of the late Justice Thurgood Marshall and retired Justice William Brennan. Contrast Cohen's formulation of the traditional principles with Justice Antonin Scalia's 1990 description of Supreme Court Indian law jurisprudence:

[O]pinions in this field have not posited an original state of affairs that can subsequently be altered only by explicit legislation, but have rather sought to discern what the current state of affairs ought to be by taking into account all legislation, and the congressional "expectations" that it reflects, down to the present day. ${ }^{4}$

The issue facing Scalia was whether an Indian tribe had criminal jurisdiction over an Indian who was not a member of that tribe for a crime committed on the reservation. ${ }^{5}$ A majority of the Court voted in conference after the oral argument to reverse a Court of Appeals decision upholding tribal jurisdiction. Justice Scalia originally voted to affirm. Justice Brennan, as senior dissenting Justice, assigued him the task of writing the dissent. Scalia later changed his mind, telling Brennan "I am sorry to desert." In the course of his "efforts to craft an opinion," he had gleaned from some recent decisions an approach that enabled the Court to readjust tribal jurisdiction and sovereignty based on a snapshot of current conditions and the expectations of non-members. Although he "would not have taken that approach as an original matter," he became convinced that the judicial prerogative was now "too deeply

4. Memorandum from Justice Antonin Scalia to Justice William J. Brennan, Jr., (Apr. 4, 1990) (Duro v. Reina, No. 88-6546) [hereinafter Scalia Duro Memo], in Papers of Justice Thurgood Marshall (reproduced from the Collections of the Manuscript Division, Library of Congress) (on file with author) [hereinafter Marshall Papers]. These remarkable papers were opened to researchers after Justice Thurgood Marshall's death, and Justice William Brennan's papers also have been selectively opened to serious scholars.

5. Duro v. Reina, 495 U.S. 676 (1990). 
imbedded in our jurisprudence to be changed." Hence he joined in Justice Kennedy's majority opinion, which extended the Court's denial of tribal criminal jurisdiction over non-Indians in Oliphant $v$. Suquamish Indian Tribe ${ }^{7}$ to the more difficult question of jurisdiction over non-member Indians. ${ }^{8}$

During the modern era, the Court regularly extended foundational principles to contemporary contexts, affording tribes the legal security to exercise broad sovereignty. But the Court then became susceptible to arguments that the impacts on non-Indians were too severe, and began aberrational departures from the presumption that tribal sovereignty survives until curtailed by Congress. This new subjectivist approach, candidly described by Scalia, has influenced a growing number of Court decisions. Nevertheless, the Court has not openly rejected the traditional principles Cohen described, and the Justices continue to profess deference to congressional authority over the scope of aboriginal powers and rights. Particularly when non-Indian interests are not seriously threatened, the Court often recites and sometimes acts upon foundation principles.

It is the thesis of this Article that although the most senior members of the present Court are committed to the subjectivist approach to Indian sovereignty, and others are often attracted to it, traditional doctrine can be redeemed. Most of the Court's current members have simply not taken enough interest, and none has assumed intellectual leadership, in the field of Indian law. All have been compliant at times, accepting subjectivist rationales in decisions that curtail tribal sovereignty. However, the newer members of the Court are in a position to determine whether Indian law is brought back on course with fundamental principles, or whether it will continue as a rudderless exercise in judicial subjectivism.

6. Scalia Duro Memo, supra note 4 .

7. 435 U.S. 191 (1978).

8. The historical evidence for Justice Rehnquist's "assumption" that tribes took no jurisdiction over non-Indians was itself thin. See Oliphant, 435 U.S. at 203; see also Criminal Jurisdiction of Indian Tribes over Non-Indians, 77 Interior Dec. 113 (1970), cited in Oliphant, 435 U.S. at 200-01 \& n.11 (opinion of Solicitor, withdrawn in 1974 but not replaced, affirming 1878 district court decision denying Indian courts criminal jurisdiction over non-Indians).

As for Duro, the available evidence contradicts the assumption that Congress intendcd any distinction among Indians based on tribal membership. Congressional statutes, for instance, did not distinguish non-member Indians when defining federal criminal jurisdiction. See, e.g., Indian Country Crimes Act, 18 U.S.C. $\$ 1152$ (1994) ("This section shall not extend to offenses committed by one Indian against the person or property of another Indian ....") (emphasis added); Major Crimes Act, 18 U.S.C. $\$ 1153$ (1994) ("Any Indian who commits against the person or property of another Indian or other person any of the following offenses... within the Indian eountry, shall be subject to the same law and penalties as all other persons committing any of the above offenses, within the exclusive jurisdiction of the United States.') (emphasis added). 
I

\section{The "Modern ERA": BuILding on Foundation Principles}

\section{A. Tribes in the Courts Historically: The Foundations}

Felix Cohen wrote triumphantly of the Court as a bulwark against state and federal incursions into the realm of tribal self-government. The foundation principles iterated by Cohen trace back to three landmark opinions of Chief Justice John Marshall, Johnson v. McIntosh, ${ }^{9}$ Cherokee Nation v. Georgia, ${ }^{10}$ and Worcester v. Georgia," the "Marshall trilogy."12 Marshall agonized over how to rationalize the young United States government's control of the Indian nations. If tribes were governments with capacity to sign treaties and cede territory, they had the qualities of sovereigns when Europeans arrived. Marshall conceded that Indians were "a distinct people, divided into separate nations, independent of each other and of the rest of the world, having institutions of their own, and governing themselves by their own laws." 13 Indeed, he went out of his way to describe tribal sovereignty in ringing, unmistakable terms: "national character," "right of self-government," "nations capable of maintaining the relations of peace and war," "distinct, independent political communities," "Indian nations," "political existence," and "pre-existing power of the nation to govern itself."14

Marshall justified the new government's domination of these native nations through what has become known as the "discovery doctrine."15

9. 21 U.S. (8 Wheat.) 543 (1823).

10. 30 U.S. (5 Pet.) 1 (1831).

11. 31 U.S. (6 Pet.) 515 (1832).

12. "In the Marshall Trilogy ... the Supreme Court handed down opinions in 1823,1831 , and 1832 that continue to form much of the foundation of federal Indian law." DAvid H. GETCHES \& Charles F. Wilkinson, Cases and Materials on Federal Indian Law 37 (2d ed. 1986). These cases are discussed in Jill Norgren, The Cherokee Cases: The Confrontation of Law AND Politics (1996), and Joseph C. Burke, The Cherokee Cases: A Study in Law, Politics, and Morality, 21 Stan. L. Rev. 500 (1969).

13. Worcester, 31 U.S. at 542-43.

14. Id. at 547-62.

15. There was an understanding among European nations that explorers had the power to claim "discovered" territory on behalf of the countries that commissioned their voyages. Johnson, 21 U.S. at 572-77. The concept was accepted by leading intemational law commentators of the time. See EMmerich de Vattel, The Law of Nations, bk. 1, ch. 1, § 11, cited in Johnson, 21 U.S. at 568. The discovery doctrine has been traced to the theory of universal papal jurisdiction, which holds that the Pope is vested with supreme spiritual jurisdiction over the souls of all humankind. See Robert A. Williams, Jr., The Medieval And Renaissance Origins of the Status of the American Indian in Western Legal Thought, 57 S. Cal. L. Rev. 1, 11 (1983); see generally L.C. GreEN \& OlIVE P. Dickason, The LaW of Nations aNd THE NEW World (1989). This unrestricted jurisdiction allowed the pope to sanction and legitimate assertions of authority over aboriginal people and their lands, as he had for the Crusades of the eleventh to thirteenth centuries. David H. GeTches ET Al.., Cases and Materials on Federal Indian Law $42-47$ (3d ed. 1993). In May 1493, Pope Alexander VI (1492-1503) issued a papal bull declaring that "whereas Columbus had come upon lands and people 'undiscovered by others ... well disposed to embrace the Christian faith,' all the lands discovered or to be discovered in the name of the Spanish Crown in the region legally belonged to Ferdinand and 
He invoked international law to confirm what the United States had presumed: that "discovering" nations got the exclusive right to purchase "such lands as the natives were willing to sell"16 while tribes retained the "degree of sovereignty, as the circumstances of the [Indian] people would allow them to exercise."17 In Worcester v. Georgia, Marshall held that the specific congressional power over Indian affairs expressed in the Indian Commerce Clause embedded the right of discovery in the Constitution. He also rationalized federal power over formerly sovereign governments as essential to fulfilling a "duty of protection" assumed by the federal government in various treaties with the Indians. ${ }^{18}$ By equating a "right of discovery" with conquest of the tribes, the Marshall trilogy gave the United States, as successor to the Europeans, all the powers of a conqueror. ${ }^{19}$

Isabella." Williams, supra, at 33 (quoting 2 SAMUel Ex.ot Morison, Admiral of the OcEAN SeA: A Life of Christopher Columbus 22 (1942)). This grant troubled some clerics and legal scliolars. The Dominican priest Franciscus de Victoria sought to exclude land occupied by aboriginal peoples from the reach of the discoverers' authority: "Now the rule of the law of nations is that what belongs to nobody is granted to the first occupant.... And so, as the object in question was not without an owner, it does not fall under the title which we are discussing." FRANciscus DE Victoria, De Indis et de Iure Belli Relectiones 139 (Ernest Nys ed. \& John Pauley Bate trans., Carnegie lnstitution of Washington 1917).

Discovery was incorporated into English jurisprudence, which distinguished hegemony over Christian and non-Christian kingdoms:

All infidels are in law perpetui inimici, perpetual enemies (for the law prcsumes not that they will be converted, that being remota potentia, a remote possibility) for between them, as with the devils, whose subjects they be, and the Christian, there is perpetual hostility, and can be no peace... a Pagan cannot have or maintain any action at all [in the King's courtsl.

And upon this ground there is a diversity between a conquest of a kingdom of a Christian King, and the conquest of a kingdom of an infidel.

Calvin's Case, 77 Eng. Rep. 377, 398 (K.B. 1608).

16. Worcester, 31 U.S. at 545.

17. Johnson, 21 U.S. at 587.

18. The Court stretched historical fact when it said that the exclusive right to take conveyances of land from the tribes, assumed by the British and inherited by the United States, originated in the Indians' need for protection. In fact, the Indians were more numerous and stronger in many places in the early days of colonization. The eventual threat to Indian security was from various Europeans competing for land. The need for protection, then, was an exigency created by colonialism itself. But Marslaall turned it into as noble a principle as it could be, recharacterizing it as a duty of protection. This obligation to the Indians has been used in later Supreme Court decisions to define a fiduciary relationship between tribes and the United States and to support exercises of federal power. See, e.g., United States v. Kagama, 118 U.S. 375, $383-84$ (1886).

19. The underlying assumption was that tribes had been effectively subjugated, and thus were brouglit under the legislative power of Congress to the extent necessary to control them. Of course, the Europeans did not "conquer" all the Indian tribes of the continent in the usual sense; the history is one of encroachments by settlers that led to the Indians' being gradually driven out. Shoshone Tribe v. United States, 11 Indian Cl. Comm'n 387, 416 (1962) (stating that gradual encroachment by whites resulted in taking of Indian lands by (lie United States). Cf. Judith V. Royster, Mineral Development in Indian Country: The Evolution of Tribal Control over Mineral Resources, 29 TuLsA LJ. 541, 546 (1994). Many tribes more or less voluntarily consented to treaties and other agreements with the United States (or with England or another European nation that earlier claimed territory now within the United States). E.g., 1785 Treaty of Hopewell with the Cherokees, reprinted in DocumENTs of 
Critics have argued that the doctrine perpetuated by the Marshall trilogy and reported by Cohen unduly dignifies a congressional power over Indian affairs based on a self-legitimating colonialist theory. ${ }^{20}$ U1timately, that theory looks to a thin rationalization of European "discovery" of the continent to justify the United States' assumption of control over aboriginally sovereigu tribes. Arguments abound over the morality of a body of law rooted in "conquest" or "discovery" and over the pernicious potential of plenary power of Congress to divest and alter the powers of Indian tribes. ${ }^{21}$

Throughout the trilogy, Marshall hinself exhibited a self-conscious concern with the moral justification for a theory that allowed Europeans to extinguish Indian land title and to curb, by their very presence, preexisting powers of tribal self-government. ${ }^{22}$ Whatever frailty the

United States Indian Policy 6-8 (Francis Paul Prucha ed., 2d ed. 1990); Treaty of Peace Between the French, Iroquois, and Other Nations, reprinted in THE HISTORY AND CULTURE OF IroquoIS DIPLOMACY 137-53 (Francis Jennings ed., 1985). The United States made treaties with over 100 Indian nations between 1778 and 1871. ARLENE Hirschfelder \& MARTHA KREIPE DE montaño, The Native American Almanac: A Portrait of Native america Today 53 (1993).

20. See, e.g., Russel Lawrence Barsh \& James Youngblood Henderson, The Road: INDIAN TRIBES AND POLITICAI LIBERTY $47-49$ (1980); Robert A. Williams, Jr., Encounters on the Frontiers of International Human Rights Law: Redefining the Terms of Indigenous Peoples' Survival in the World, 1990 DukE L.J. 660, 672-76. Scholars have attributed the doctrine of the foundation principles to the colonizing forces of the fifteenth to seventeenth centuries, when European exploration of the new world was rationalized in terms of the inferior moral status of native peoples and varnished with religious purposes. See Robert A. Williams, JR., The AMERICAN INDIAN IN Western Legal Thought: The Discourses of Conguest 316-17 (1990); Documents of AMERICAN History 5-6 (Henry Steele Commager ed., 8th ed. 1968). These apparently corrupt origins have led some scholars to call for "decolonizing" Indian law and repudiating the foundation principles. See generally Robert N. Clinton, Redressing the Legacy of Conquest: A Vision Quest for a Decolonized Federal Indian Law, 46 ARK. L. REv. 77 (1993); Frank Pommersheim, Liberation, Dreams, and Hard Work: An Essay on Tribal Court Jurisprudence, 1992 Wis. L. Rev. 411.

21. See, e.g., Milner S. Ball, Constitution, Court, Indian Tribes, 1987 AM. B. Found. REs. J. 1, 61; David Williams, Legitimation and Statutory Interpretation: Conquest, Consent, and Community in Federal Indian Law, 80 VA. L. REv. 403 (1994). The debate is joined in the following interchange: Robert A. Williams, Jr., The Algebra of Federal Indian Law: The Hard Trail of Decolonizing and Americanizing the White Man's Indian Jurisprudence, 1986 Wis. L. REv. 219 [hereinafter Williams, The Algebra of Indian Law]; Robert Laurence, Learning to Live with the Plenary Power of Congress over the Indian Nations: An Essay in Reaction to Professor Williams' Algebra, 30 ARIz. L. REv. 413 (1988); Robert A. Williams, Jr., Learning Not to Live with Eurocentric Myopia: A Reply to Professor Laurence's Learning to Live with the Plenary Power of Congress over the Indian Nations, 30 ARIZ. L. REV. 439 (1988).

22. Marshall wrote: "The extravagant and absurd idea, that the feeble settlements made on the sea-coast, or the companies under whom they were made, acquired legitimate power by them to govern the people, or occupy the lands from sea to sea, did not enter the mind of any man." Worcester v. Georgia, 31 U.S. (6 Pet.) 515, 544-45 (1832). While expressing discomfort with the legal fictions that allowed Europeans to assert title over land occupied by aboriginal people, he declined to "enter into the controversy, whether agriculturists, merchants and manufacturers, have a right, on abstract principles" to make such an assertion. Johnson v. McIntosh, 21 U.S. (8Wheat.) 543, 588-89 (1823). He later asked: 
"discovery doctrine" suffered as a matter of natural law, however, Marshall found its ultimate justification in positive law. As he wrote in Johnson v. McIntosh:

However extravagant the pretension of converting the discovery of an inhabited country into conquest may appear; if the principle has been asserted in the first instance, and afterwards sustained; if a country has been acquired and held under it; if the property of the great mass of the community originates in it, it becomes the law of the land, and cannot be questioned. ${ }^{23}$

Getting beyond his apparent moral qualms, ${ }^{24}$ Marshall concluded fatalistically that "[c]onquest gives a title which the courts of the conqueror

Did these adventurers, by sailing along the coast, and occasionally landing on it, acquire for the several governments to whom they belonged, or by whom they were commissioned, a rightful property in the soil, from the Atlantic to the Pacific; or rightful dominion over the numerous people who occupied it? Or has nature, or the great Creator of all things, conferred these rights over hunters and fishermen, on agriculturists and manufacturers?

Worcester, 31 U.S. at 543.

23. Johnson, 21 U.S. at 591.

24. Some scholars question the authenticity of Marshall's professed agony over the morahty of the doctrine and its contradictions with natural law. "IT]he original legal rules and principles of federal Indian law set down by Marshall ... ensured that future acts of genocide would proceed on a rationalized, legal basis." Williams, supra note 20, at 317 . Constitutional historian G. Edward White links MarshalI's use of pejorative language, such as references to "fierce savages" in Johnson, 21 U.S. at 590, to his rejection of Indians' natural law rights. G. EDWARD WHITE, The Marshall Court and Cultural Change: 1815-35, at 710 (1988). "Natural law, Marshall intimated in Johnson v. McIntosh, was not designed to apply to cases involving persons whose 'character and habits' were so markedly different from 'civilized' whites." Id. at 711. White was referring to Marshall's statement, "Although we do not mean to engage in the defence of those principles which Europeans have applied to Indian title, they may, we think, find some excuse, if not justification, in the character and habits of the people whose rights have been wrested from them." Johnson, 21 U.S. at 589. White compares Marshall's refusal to enforce Indians' natural rights with the circumscribed reading Marshall gave to rights guaranteed by the Constitution in cases involving blacks:

Distinctions between written and unwritten rights began to creep into cases involving racial minorities, and eventually the cases could be read as standing for two propositions: first, that the unwritten natural rights of black slaves and Indians could not be used as sources for their legal protection; second, that to the extent that principles of natural justice had been incorporated into the written language of the Constitution, that language did not, in the main, apply to slaves or Indians.

WHITE, supra, at 681 .

Similarly, Jill Norgren has agreed that, with the Cherokee cases, "the Marshall Court helped to establish the view that Indians were inferior and thus could be appropriately denied the full legal regard of the United States that would otherwise be demanded by natural law." NoRGREN, supra note 12, at 9. She concludes that the Chief Justice "was willing to sacrifice the rights of the Cherokee people" for political motives, and that his characterization of tribes as "domestic dependent nations" instead of declaring them foreign nations was a "transparent ploy." Id. at 109. She deplores the result as based on "tortured and ethnocentric legal distinctions," id. at 105 , and partly because of this decision she concludes that "federal Indian law today is deeply flawed," id. at 151 . She necessarily reports, though, that the courageous and visionary Chief John Ross of the Cherokee Nation viewed the Cherokee Nation v. Georgia decision favorably at the time it was decided and called it the "foundation" for asserting the Cherokee's legal rights. Id. at 110. 
cannot deny, whatever the private and speculative opinions of individuals may be, respecting the original justice of the claim which has been successfully asserted."25

I do not join here in the well-developed debate over the legitimacy of these original principles. It is too late in the day to revisit two centuries of consistently and firmly reiterated precedent or to expect a basic reformation of the historical legal relationship of the United States to Indian tribes. ${ }^{26}$ Furthermore, I am not convinced that asking courts to apply notions of justice or equity in individual cases will provide sufficient or consistent support for tribal government. ${ }^{27}$ Indeed, the track record of the present Court shows the unfortunate consequences of a judicial attempt to bring Indian law in line with today's values in order to attain what the Court perceives the "current state of affairs ought to be."28 Entrusting courts to modernize legal principles as social values

Considering their milieu, I view the Marshall trilogy as remarkable for their limitations on state power and recognition of tribal autonomy. It is difficult to imagine the young nation's Court being less restrictive of Indian rights in such hotly charged cases.

25. Johnson, 21 U.S. at 588.

26. Proposals to revamp the essential relationship between the United States and Indian tribes have consumed considerable scholarly energy. See, e.g., BARSH \& HENDERSON, supra note 20, at 279-83 (advocating an amendment to the United States Constitution giving tribes a status comparable to that of states); James A. Casey, Sovereignty by Sufferance: The Illusion of Indian Tribal Sovereignty, 79 CoRNEll L. REv. 404, 436-48 (1994) (proposing free association agreements between tribes and the United States); Steven Paul McSloy, Back to the Future: Native American Sovereignty in the 21st Century, 20 N.Y.U. Rev. L. \& Soc. Change 217, 280-86 (1993) (arguing for reinstituting the international status of tribes).

27. Cf. Patrick Macklem, Distributing Sovereignty: Indian Nations and Equality of Peoples, 45 StaN. L REv. I311, 1315 (1993) (arguing for the principle of "equality of peoples" as an appropriate basis for strengthening the commitment to Indian tribal govermment); Nell Jessup Newton, Federal Power over Indians: Its Sources, Scope, and Limitations, 132 U. PA. L REv. I95, 198 (1984) (advocating intermediate judicial scrutiny of federal encroachments on tribal sovereignty).

28. Professor Frickey has produced a major study of interpretation in Indian law that eschews "foundationalist approaches" as "too hollow or too abstract to accommodate our colonial heritage with the human values of the late twentieth century." Philip P. Frickey, Congressional Intent, Practical Reasoning, and the Dynamic Nature of Federal Indian Law, 78 CALIF. L. REv. 1137, I239 (1990). The Article argues that "practical reason," which emphasizes the contemporary context of decisions, should replace the use of traditional principles, i.e., foundationalism. This extends to the field of Indian Iaw a theory that Professor Frickey, along with Professors DanieI Farber and William Eskridge, has applied to statutory interpretation and First Amendment issues. See Daniel Farber \& Philip P. Frickey, Practical Reason and the First Amendment, 34 UCLA L. REv. 16I5 (1987); William N. Eskridge, Jr. \& Philip P. Frickey, Statutory Interpretation as Practical Reasoning, 42 STAN. L. REv. 321 (I990).

"Practical reasoning" is described as an antiformal altemative to foundationalism, one that is dynamic and looks to "all potentially relevant sources" for statutory meaning. Frickey, Congressional Intent, supra, at 1208. Frickey also argues that the critical legal studies rejection of the foundation concepts for their poisoned roots in the ideas of discovery and plenary federal power is itself effectively bound by formal theory and is thus essentially "foundational." Id. at 1204-07. However, Frickey concludes by recognizing some merit in "accepting foundationalist concepts for what they can accomplish." Id. at 1239. He concedes that "Marshall's opinions reveal more hermeneuticaI spirit and help establish a more normatively attractive vision of our federal Indian law tradition." Id. at 1224. 
evolve is particularly inappropriate to Indian tribal survival, where the subject matter is culturally estranged from the decision maker. Rather, I believe that tribal self-governance and Indian rights are best preserved within the established constitutional and legal order..$^{29}$ My concern is that Indian rights are losing the limited protection they had as the Court forsakes foundation principles and expands the ambit of control over Indian tribes to include not just congressional but also judicial power to redefine and restrict tribal sovereignty.

Worcester lays the cornerstone for the legal system's continuing recognition of tribal sovereignty. The battle in that case was over whether the State of Georgia could impose its laws on the Cherokees. Moved by federalist convictions and protective of the national control over Indian affairs won at the Constitutional Convention, Marshall insisted on the supremacy of federal over state power..$^{30}$ Marshall's opinion found Georgia's law void as "repugnant to the Constitution, treaties, and laws of the United States,"31 using contemporary terms for federal preemption. The Court's opinion stressed the continuing sovereignty of tribes, referring no less than sixteen times to the concept of "selfgovernment." Reservation boundaries became a barrier to state power:

The Cherokee nation ... is a distinct community, occupying its own territory, with boundaries accurately described, in which the laws of Georgia can have no force, and which the citizens of Georgia have no right to enter, but with the assent of the Cherokees themselves, or in conformity with treaties, and with the acts of Congress. ${ }^{32}$

More recently, Professor Frickey has praised the three nineteenth-century foundational cases as articulating a "complex, institutionally sensitive interpretive scheme," an approach he sees as essential to the constitutional structure. Philip P. Frickey, Marshalling Past and Present: Colonialism, Constitutionalism, and Interpretation in Federal Indian Law, 107 HARv. L. REv. 381, 417 (1993). He even argues that errors in several recent cases can be attributed to the Court's straying from Marshall's foundational legacy, $i d$. at $418-26$, and that the paradigm for deciding future Indian law cases should be Marshall's approach in Worcester, id. at 427-39.

29. Cf. Richard B. Collins, Indian Consent to American Government, 31 ARIz. L. REv. 365, 381-82 (1989) (arguing that the Constitution's structure and procedure protect Indian rights by placing power over tribes in the federal government and by blunting majoritarian oppression).

30. The preservation of tribal government over enclaves of Indian country vas a triumph for Marshall made possible by the presumption that the tribes' sovereignty was subject to the legislative authority of the United States. Marshall drew support for this presumption from the lndian Commerce Clause, U.S. Const. art. 1, $\S 8$, cl. 3, which ceded to the Congress "powers ... of regulating commerce... with the Indian tribes." See Worcester, 31 U.S. at 559 . The clause was intended to resolve the contentious matter of whether the states or the federal government would exercise governmental authority with respect to the Indian tribes. It ended the state role in Indian affairs that existed under the Articles of Confederation. This was one of the issues whose resolution made accord possible among the constitutional framers. See generally THE Constitutional Convention and the Formation of the Union (Winton U. Solberg ed., 2d ed. 1990).

31. Worcester, 31 U.S. at 562-63.

32. Id. at 561 . 
Worcester thus gave important definition to the doctrine of federalism, preserving tribal sovereignty subject only to abridgment by the national government.

Had the Worcester Court found the tribes' rights totally extinguished, the states where they resided likely would have ousted them from their lands and completely obliterated their governments. Had the Court recognized the tribes' full political independence, however, the decision probably would have been ignored by the states. Although the Court did not reach either of these conclusions, Marshall's solicitude for the Cherokee Nation and the limits he placed on Georgia incited a constitutional crisis that remains one of the most severe and acrimonious in our history. ${ }^{33}$ Indeed, the votes and opinions of Marshall's fellow Justices suggest that he went as far as he could in sustaining tribal selfgovernment without losing a majority ${ }^{34}$

Certainly tribes have not always fared well under the foundation principles. Most notably, the treaties that remain a primary source of Indian rights also led to substantial diminution of tribal autonomy. The early treaties typically memorialized the "discovery" principle by submitting the tribes' external political affairs to the United States' control. Some Indian treaties recited this political submission in broad terms, and others dealt crisply with specific issues, but virtually all Indian treaties were premised on the United States' political domination of the tribes. The treaties generally reflect a relationship of both political and economic dependence. ${ }^{35}$

It is precisely because of the unequal bargaining power that characterized treaty negotiations and the single-minded determination of the United States to achieve its own purposes ${ }^{36}$ that the courts have long insisted on construing treaties favorably to the Indians. ${ }^{37}$ Given the circumstances surrounding the treaties, the momentous concessions made by the tribes, and the tribes' dependent relationship (partly a result of the treaties themselves), it would be unjust to read the agreements as giving up any rights beyond those ceded in clear and specific terms. This reasoning is consistent with one of Felix Cohen's cardinal princi-

33. The outcry of the states was so heated that the executive branch took no steps to enforce the decision for almost a year. See Burke, supra note 12, at 524-31.

34. In Cherokee, with seven Justices on the Court, Justices Johnson and Baldwin wrote concurring opinions while Justice Story joined Justice Thompson's dissent. In Worcester, Justice McLean concurred and Justice Baldwin dissented, though a dissenting opinion was never delivered to the court reporter.

35. Francis Paul Prucha, american Indian treaties: The History of a Political ANOMALY 5-6, 65-66 (1994).

36. Id. Father Prucha's account of the treaty-making process documents the treaties' importance to non-Indian political and economic interests and their essential role in implementing government policies during the nation's first hundred years.

37. See infra notes $210-215$ and accompanying text. 
ples of Indian law: great power over Indian affairs is conceded to the federal government, but only those Indian rights expressly extinguished are lost. . $^{38}$

Legislation has also amputated some of the tribes' governmental rights. For instance, punishment of major crimes on reservations was federalized after government agents mouuted a campaign against one tribe's allegedly lenient handling of a murderous blood feud among Sioux Indians. ${ }^{39}$ Other federal criminal laws have also displaced a measure of tribal authority ${ }^{40}$ On the other hand, in construing such legislation, courts have applied rules of construction favoring Indians that were developed in treaty cases. ${ }^{41}$ While the analogy is imperfect, federal laws, like the treaties, were not founded on a relationship of mutuality. Rather, they have arisen in a context of enormous federal power over Indians.

More damaging to tribal sovereignty than direct abrogation of governmental authority has been the tribes' loss of land. Tribes have ceded much territory to the government in treaties. Remaining tribal lands were often distributed under statutory programs to individual Indians and non-Indian settlers. These events have dramatically undermined the tribes' ability to govern, by shrinking and then carving up their land base. Placing tribes on reservations often separated them from their livelihoods and thus from the cultural practices and traditions that made tribal governance relevant and powerful.

The most poignant extinguishment of tribal sovereignty through dispossession was the allotment policy of the late nineteenth century. Tribal land holdings were parceled out to tribal members in allotments of 160 acres, and "surplus" lands were opened to non-Indian homesteaders. Ultimately, a majority of all Indian lands passed from native ownership under this policy. ${ }^{42}$ President Theodore Roosevelt ominously called this partition of communally held lands " $a$ mighty pulverizing engine to break up the tribal mass." ${ }^{\prime 3}$ Except for the tragically mis-

38. COHEN (1941), supra note 1, at 123.

39. The Major Crimes Act of 1885,18 U.S.C. $\S 1153$, which supplanted tribal with federal authority for the most serious crimes, followed closely on the heels of the Court's decision to deny federal jurisdiction over a murder committed between tribal members in Ex parte Crow Dog, 109 U.S. 556 (1883).

40. See, e.g., Assimilative Crimes Act, 18 U.S.C. $\S 13$ (1994); Indian Country Crimes Act, 18 U.S.C. § 1152 (1994); Organized Crime Control Act, 18 U.S.C. $§ 1955$ (1994).

41 See infra note 21.

42. COHEN (1982), supra note 2, at 138. See infra text accompanying notes 223-251 (discussing allotment policy).

43. 35 CONG. REC. $S 90$ (1901). 
guided "termination" program of the 1950s and 1960s, Congress has not adopted a policy of land dispossession since the allotment era. ${ }^{44}$

The tribes have suffered undeniably serious losses of land and sovereignty. Yet, given the apparent reach of Congress" "plenary power," it is remarkable that tribes have survived as well as they have. Although the Court historically has refused to second-guess congressional decisions even when they divest the Indians of rights and powers, ${ }^{45}$ the Court has not hesitated to limit state power to curb exercises of state governmental authority that threaten the integrity of tribal governments. ${ }^{46}$ Congressional deliberation has often checked the excesses of states and has created a forum that, particularly in modern tinies, has given tribes the benefits of the transparency and temperance of public political debate, open to nioral arguments and informed public opinion. The trust relationship with the federal government, stemming from the federal duty of protection, is more difficult to enforce judicially than the limits on states' rights, but it can be asserted to challenge governmental bad faith and mismanagement in Indian affairs. ${ }^{47}$ Moreover, Marshall's

44. The termination effort is still vivid in the memories of Indians who lived through or heard about it. The effort aimed to end the special relationship between tribes and the federal government. Communally held lands were typically distributed to individual tribal members, reservations extinguished, and lands and Indians subjected to state law. Federal obligations also ceased. In the name of freeing tribes from heavy federal supervision, some 1,362,000 acres were "liberated" from government restrictions and from tribal governance. Charles F. Wilkinson \& Eric R. Biggs, The Evolution of the Termination Policy, 5 AM. INDIAN L. Rev. 139, 151-54 (1977). For a full description of the termination policy, see CoHEN (1982), supra note 2, at 152-80. The homogenizing ethic that inspired the termination policy also moved Congress in 1953 to reallocate jurisdictional prerogatives in Indian country, shifting responsibility for many criminal and civil cases from federal to state courts. See 18 U.S.C. $\$ 1162$ (1996).

45. See, e.g., United States v. Chavez, 290 U.S. 357, 363 (1933); United States v. Candelaria, 271 U.S. 432, 439 (1926); United States v. Sandoval, 231 U.S. 28, 46 (1913); Tiger v. Western Inv. Co., 221 U.S. 286, 315 (1911); United States v. Holliday, 70 U.S. (3 Wall.) 407, 419 (1865). Early decisions shielded such legislation from challenge with the political question doctrine. The Court no longer regards the political question doctrine as an absolute barrier to justiciability. Constitutional challenges to discriminatory treatment are now permitted, but the Court will not disturb a legislative judgment if "the special treatment can be tied rationally to the fulfillment of Congress' unique obligation toward the Indians." Delaware Tribal Business Comm. v. Weeks, 430 U.S. 73, 85 (1977) (citing Morton v. Mancari, 417 U.S. 535, 555 (1974)). The Court has found federal power adequate to support congressional legislation unilaterally abrogating an Indian treaty by parcelling out tribal land to individual tribal members and non-Indians, Lone Wolf v. Hitchcock, 187 U.S. 553 (1903), and statutes that unilaterally usurp tribal jurisdiction over major crimes on reservations, United States v. Kagama, 118 U.S. 375 (1886). More recently, however, the Court has said that Indians may challenge the presumption of congressional good faith (announced in Lone Wolf) in cases alleging a Fifth Amendment taking of Indian land. See United States v. Sioux Nation, 448 U.S. 371 (1980).

46. E.g., New Mexico v. Mescalero Apache Tribe, 462 U.S. 324, 332 (1983); White Mountain Apache Tribe v. Bracker, 448 U.S. 136, 142-44 (1980); Williams v. Lee, 358 U.S. 217, 223 (1959).

47. See generally Reid Peyton Chambers, Judicial Enforcement of the Federal Trust Responsibility to Indians, 27 StAN. L. Rev. 1213 (1975). See also United States v. Mitchell, 463 U.S. 206, 226 (1983); Arizona v. California, 460 U.S. 605, 649 (1983) (Brennan, J., concurring in part and dissenting in part); Morton v. Ruiz, 415 U.S. 199, 236 (1974); Seminole Nation v. United States, 316 U.S. 286, 296 (1942) (noting "distinctive obligation of trust incumbent upon the Government in its 
landmark trilogy has supported development of a solid body of law largely favorable to Indian tribal governments.

Since the foundation cases, the Court has repeatedly refused to place its own limits on tribal self-government. In Worcester, Justice McLean's concurring opinion implied that the passage of time, the proximity to non-Indians, and other changing circumstances could erode a tribe's sovereign status and extend state jurisdiction over the reservation. ${ }^{48}$ The Court, however, declined to decide that it was a judicial function to readjust the sovereign status of tribes. Indeed, at least until recently, the Court has reserved this initiative to the political branches of government. ${ }^{49}$

\section{B. The McBratney Exception}

For almost a century and a half, Worcester's announcement of reservation boundaries as barriers to state jurisdiction described the law of the land. The most notable exception to this rule was United States $v$. $M c B r a t n e y,{ }^{50}$ in which the Court denied the effect of federal legislation, apparently giving the United States district court jurisdiction to try all murder cases arising on Indian reservations. The Court held the statute was not intended to displace the jurisdiction over non-Indian citizens that a state automatically acquires when it is admitted to the Union. McBratney thus conflicts with Worcester's holding that Georgia had no jurisdiction over the non-Indians on the Cherokee Reservation. The

dealings with these dependent and sometimes exploited people"). The potential of the trust duty to protect Indian land and resources is lucidly developed in Mary Christina Wood, Indian Land and the Promise of Native Sovereignty: The Trust Doctrine Revisited, 1994 UTAH L. REv. 1471; Mary Christina Wood, Protecting the Attributes of Native Sovereignty: A New Trust Paradigm for Federal Actions Affecting Tribal Lands and Resources, 1995 UTAH L. Rev. 109.

48. Justice McLean's concurrence says that federal power over Indians within a state "must be limited by circumstances," yet he reserved the question whether it was appropriate for a court to make such a determination under the facts of that case: "The point at which this exercise of [governing] power by a state would be proper, need not now be considered; if, indeed, it be a judicial question." Worcester, 3I U.S. at 593. His views on the subject became clearer in a decision he wrote as a circuit judge a few years after Worcester, upholding Ohio's assertion of jurisdiction over the small Wyandott Reservation by applying state law, not the federal Nonintercourse Act, to a nonIndian who stole a horse from an Indian. United States v. Cisna, 25 F. Cas. 422 (C.C. Ohio 1835) (No. 14,795). He relied on the fact that the reservation was "surrounded by a dense white population [that had] daily intercourse with the Indians" to surmise that continued application of federal laws would be "wholly unsuited to the condition of the Wyandott tribe." Id. at 424.

49. See United States v. Sandoval, 231 U.S. 28, 46 (1913) (holding that termination of guardianship is a question for Congress, not the courts); United States v. Holliday, 70 U.S. (3 Wall.) 407,419 (1865) (holding that "it is the rule of this court to follow the action of the executive and other political departments of the government"). See also Moe v. Confederated Salish \& Kootenai Tribes, 425 U.S. 463,476 (1976) (refusing to accept the proposition that a local tribe had become so integrated with surrounding non-Indian communities that the State of Montana should be permitted to exercise governmental power over it).

50. I04 U.S. 621 (1881). Accord Draper v. United States, 164 U.S. 240 (I896). 
leading treatise in Indian law suggests the McBratney Court misinterpreted the federal statute in question..$^{51}$

Worcester and McBratney are distinguishable only if one assumes that the murder of one white by another in McBratney was of no concern to the tribe on whose reservation it took place. As such, the crime fell outside the ambit of "Indian affairs," the field in which Congress was legislating when it passed the federal murder statute. By contrast, the regulation of non-Indian entry and activity in Worcester had a great effect on the tribe, was intimately related to the regulation of Indian commerce, and was therefore squarely within the realm of Indian affairs. Later cases embrace this distinction, specifying that the McBratney exception applies only to "crimes between whites and whites which do not affect Indians." \$2

The McBratney Court was moved by the reality that non-Indians lived and owned land on reservations as a result of federal policies. Inexorable pressure for western lands where non-Indian homesteaders could settle led to paring the boundaries of reservations and eventually to opening lands within reservations for settlement by non-Indians. The typical allotment program offered a portion of reservation land for nonIndian ownership. ${ }^{53} \mathrm{~A}$ variety of other laws also invited non-Indians to reside on reservations. ${ }^{54}$

Congress has enacted no broad limitation on tribal jurisdiction over non-Indian land on reservations. Indeed, even when parcels are sold off and occupied by non-Indians, they remain "Indian country" under federal law and are therefore subject to tribal jurisdiction. ${ }^{55}$ It is unsur-

51. CoHen (1982), supra note 2, at 264-65.

52. New York ex rel. Ray v. Martin, 326 U.S. 496, 500 (1946) (emphasis added); cf. Donnelly v. United States, 228 U.S. 243, 271 (1913) (white's murder of Indian punishable under Indian Country Crimes Act; offenses committed against Indians held to be outside the scope of the McBratney exception).

53. See COHEN (1982), supra note 2, at 137; see also supra notes $42-44$ and accompanying text.

54. See, e.g., South Dakota v. Bourland, 508 U.S. 679, $687-90$ (1993) (describing the Flood Control and Cheyenne River Acts' taking of 100,000 acres of Cheyenne River Sioux reservation land for the Oahe Dam and Reservoir Project).

55. This is made clear in 18 U.S.C. $\$ 1151$ (1994), which states that:

Except as otherwise provided in sections 1154 and 1156 of this title, the term "Indian country," as used in this chapter, means (a) all land within the limits of any Indian reservation under the jurisdiction of the United States Government, notwithstanding the issuance of any patent, and, including rights-of-way running through the reservation, (b) all dependent Indian communities within the borders of the United States whether within the original or subsequently acquired territory thereof, and whether within or without the limits of a state, and (c) all Indian allotments, the Indian titles to which have not been extinguished, including rights-of-way mnning through the same.

The Supreme Court has repeatedly indicated that "Indian country" defines the reach of a tribe's civil as well as criminal jurisdiction. See, e.g., Oklahoma Tax Comm'n v. Sac \& Fox Nation, 508 U.S. 114,123 (1993) (invalidating state income and motor vehicle taxes on tribal members who live in "Indian country"); Oklahoma Tax Comm'n v. Citizen Band Potawatomi Indian Tribe, 498 U.S. 505, 513 (1991) (invalidating state cigarette tax on tribal members who live in "Indian country"); 
prising that tribal authorities should not be limited to governing tribal lands or members. A sovereign has authority over people and territory within its boundaries regardless of their citizenship or the land titles. ${ }^{56}$ Sovereignty comprehends powers greater than the right to exclude; one need only be a property owner to limit entry to land. For example, even the Elks Club can impose conditions and sanctions on members and expel non-members from its premises; Indian tribes, however, are " a good deal more than 'private, voluntary organizations."'57

A further exception to the foundation principles was carved out by a flurry of turn-of-the-century cases allowing states to tax non-Indian property on the reservation. ${ }^{58}$ Like McBratney, these incursions on tribal sovereignty can be tied to the assumption that imposition of the taxes had no direct effect on Indians or federal regulation of Indian affairs. In none of the cases was there any competing tribal regulation or tax on non-Indians, and no Indians or tribes were parties to any of the cases. ${ }^{59}$

In the end, then, Worcester's barrier to state jurisdiction over reservation activities remained unbreached, save for this handful of cases that purportedly did not implicate Indian interests. This is not to say that tribal authority over non-Indians was upheld in every case where there was an effect on Indians. Tribal justice systems rarely tried to assert jurisdiction over non-Indians on reservations. When tribes did assert control over non-Indian conduct, they sometimes found themselves frustrated by their own laws, which were often drawn narrowly (with the federal government's assistance) to apply only to Indians. ${ }^{60}$ However, in

California v. Cabazon Band of Mission Indians, 480 U.S. 202, 208 (I987) (invalidating enforcement of state gambling laws in "Indian country").

56. See COHEN (1982), supra note 2, at 250. Tribes have sovereign authority over all land and all people within the reservation unless: (I) their jurisdiction has been extinguished, (2) Congress has legislated to give the United States jurisdiction, or (3) they never had jurisdiction in the first place. Id.

57. United States v. Mazurie, 419 U.S. 544, 557 (1975) (repudiating a Court of Appeals decision equating a tribe's power to regulate liquor to that of a private club). Justice Rehnquist wrote that tribes possess "attributes of sovereignty over both their members and their territory." Id.

58. Two involved taxation of railroad rights-of-way on Indian reservations. Maricopa \& $P$. R.R. v. Arizona, 156 U.S. 347 (I895); Utah \& N. Ry. v. Fisher, 116 U.S. 28 (1885). Two more involved taxation of non-Indian-owned cattle. Wagoner v. Evans, I70 U.S. 588 (I898); Thomas v. Gay, I69 U.S. 264 (I898); see also Montana Catholic Missions v. Missoula County, 200 U.S. II8 (1906) (implying state taxing authority over non-Indian cattle).

59. In Thomas, 169 U.S. at 273-74, the Court considered and rejected the argument that because a tax on cattle grazed on a tribal reservation might affect the value of the land, the tax was effectively a levy on the Indians. The Court found the effect on Indian interests "too remote and indirect" for the tax to infringe tribal sovereignty. Id.

60. See, e.g., Alberty v. United States, I62 U.S. 499 (I896) (holding that Negro born in slavery, though made a citizen of the Cherokee Nation, was not "Indian" for purposes of tribal jurisdiction). 
the only early case involving applicability of tribal law to reach the Court, tribal jurisdiction over non-Indians was upheld. ${ }^{61}$

\section{Elaboration of Foundation Concepts in the "Modern Era"}

When Williams $v$. Lee ${ }^{62}$ inaugurated the modern era in 1959, the foundations of Indian law were still solid; the principles announced in Chief Justice Marshall's trilogy of cases continued to define the limits of tribal sovereignty. Supreme Court precedent in the area was sparse, especially with regard to jurisdiction over non-Indians, but it was clear that the Court still viewed reservation boundaries as barriers to state regulation, absent congressional indication to the contrary. The foundation doctrine had been consistently pronounced, if not always enforced, for almost a century and a half. In the modern era, it was augmented and strengthened in an extraordinary number of hardfought jurisdiction cases brought before the Court. ${ }^{63}$

The fact that few conflicts had reached the Supreme Court in the preceding years obscures the extensive jurisdictional inroads states had made on many reservations. Tribal governments were weakened first by the loss of leaders to the war effort during the 1940s, then by the unsupportive government policies of the termination era. ${ }^{64}$ Reservations, with growing non-Indian communities around them and large numbers of non-Indian residents within, were often jurisdictional vacuums that states would fill. Tribes did not resist as states began expanding beyond the criminal law and personal property tax exceptions the Court had previously created for non-Indians. Congress then specifically allowed states to take over additional criminal and civil jurisdiction under a termination-era statute, Public Law $280 . .^{65}$ Some states declined this invitation to expand their authority because of the cost, but many selectively accepted jurisdiction in order to meet perceived practical needs.

When farther-reaching state law enforceinent finally began to encounter more active tribal governments, litigation ensued. In its bellwether Williams decision, the Court vindicated tribal sovereignty in a modern context-a debt collection case brought by a non-Indian merchant against tribal members. The Court held that tribal authorities, not the Arizona state court, had jurisdiction over the inatter. Williams confirmed the modern Court's adherence to foundation principles: "[e]ssentially, absent governing Acts of Congress, the question has always been whether the state action infringed on the right of reser-

61. Morris v. Hitchcock, 194 U.S. 384 (1904) (allowing tribal taxation of non-lndian-owned cattle and horses).

62. 358 U.S. 217 (1959).

63. See WiLkinson, supra note 3, at 1-3.

64. For a description of the termination policy, see supra note 44 .

65. 18 U.S.C. $\$ 1162$ (a) (1994) (criminal); 28 U.S.C. $\$ 1360$ (a) (1994) (civil). 
vation Indians to make their own laws and be ruled by them." ${ }^{166}$ The State of Arizona had not accepted jurisdiction over civil cases pursuant to Public Law $280,{ }^{67}$ nor was state jurisdiction permitted under any other act of Congress. The State thus simply could not intrude upon the governmental enclave of the Navajo Nation. Theoretically, the decision in Williams merely reformulated established law. ${ }^{68}$ In practice, however, it ousted de facto state court jurisdiction over reservation commercial cases initiated by non-Indians throughout Indian country, and recognized the tribes' exclusive, unextinguished jurisdiction in such matters.

A landmark 1973 case clarified the import of Williams and reaffirmed the Court's commitment to tribal self-government. In McClanahan v. Arizona State Tax Commission, ${ }^{69}$ perhaps the definitive modern-era case, the Court held that Arizona could not tax income earned wholly from reservation sources by an individual Navajo residing on the reservation. ${ }^{70}$ Justice Thurgood Marshall, writing for a unanimous Court, rejected the state court's approach that would allow Arizona to tax an individual Indian's reservation income. Arizona and other states had been perverting the Court's cryptic statement in Williams prohibiting infringement of tribal sovereignty to presume that states could exercise jurisdiction on the reservation absent evidence of a direct clash with tribal government. The states had also been ignoring Williams' pivotal reference to "governing Acts of Congress," a phrase that encompasses an array of treaties and laws that typically define an area where federal policy preempts state law.

McClanahan defined the Court's approach to Indian jurisdiction cases as primarily one of "reliance on federal pre-emption." The Indian sovereignty doctrine continued to play a central role: it "provides a backdrop against which the applicable treaties and federal statutes must be read." $" 11$ The Court would focus on the federal statutes and treaties at issue, guided by the tradition of tribal self-government in Indian country that creates a presumption in favor of tribal autonomy. Thus while the treaty in McClanahan was silent as to whether the tribe was exempt from state jurisdiction, the Court determined that "the reservation of certain lands for the exclusive use and occupancy of the Navajos and the exclusion of non-Navajos from the prescribed area was meant to establish the lands as within the exclusive sovereignty of the

66. Williams v. Lee, 358 U.S. 217,220 (1959).

67. Id. at 222-23.

68. See Utah \& N. Ry. v. Fisher, 116 U.S. 28, 31 (1885) ("The authority of the Territory [of Idaho] may rightfully extend to all matters not interfering with [Indian] protection.").

69. 411 U.S. 164 (1973).

70. See id. at 179-81.

71. Id. at 172 . 
Navajos." ${ }^{72} \mathrm{McClanahan}$ elucidated that it was federal law establishing the reservation that made state laws "repugnant" in Worcester and that underlay the long-establislied rule that "Indians and Indian property on an Indian reservation are not subject to state taxation except by virtue of express authority conferred upon the state by act of Congress." ${ }^{\text {"7 }}$

McClanahan's facts involved only Indians, but the Court cliarted an approach for cases concerning non-Indians as well. The discussion of precedent suggests that if the issue had been application of the Arizona income tax to a non-Indian working on the reservation, the Court would also have begun its analysis by examining treaties and statutes that arguably might apply. The Indian sovereignty doctrine would still be relevant to the interpretation of those laws. However, Marshall acknowledged that in cases dealing "principally with situations involving non-Indians," the Court had made some departures from Worcester's flat bar to state jurisdiction based on tribal sovereignty. ${ }^{74}$ Since few federal statutes are explicit regarding state jurisdiction, ${ }^{75}$ a court must analyze whether congressional intent to preempt can be inferred from the language, legislative history, or circumstances of their enactment. It is in this context that a court could also "take account of the State's legitimate interests in regulating the affairs of nonIndians." $" 76$

\section{Revitalization of Tribal Governments}

McClanahan and the other modern-era cases supported a movement toward revitalization of tribal governments. They came at a time when new leadership was emerging on the reservations. Indian people had been galvanized by their reactions to termination policy, and then were supported by Congress and an executive branch that affirmatively favored tribal self-government. ${ }^{n}$ Reservation Indians were aided in their

72. Id. at 174-75. The Court also found state jurisdiction to be preempted by federal law, including the Buck Act of 1947, 4 U.S.C. $\$ \S 105,106(\mathrm{a}), 109$. Id. at 176-77.

73. CoHEN (1941), supra note 1, at 254. Thus, Worcester is also a preemption case. There the Court held that allowing Georgia law to control the presence of white missionaries in Cherokee territory would be "repugnant" to treaties and federal laws preserving Cherokee self-government. Worcester, 31 U.S. at 562 . "Repugnant" was a term used by the Court in early preemption cases. McClanahan was the first Indian case to use the term "pre-emption." 411 U.S. at 172.

74. McClanahan, 411 U.S. at 171, citing cases cited supra, notes 50, 52, 58; see also infra note 258.

75. See, e.g., Indian Mineral Leasing Act of 1938, 25 U.S.C. $\$ \S 396 \mathrm{a}-\mathrm{g}$, cited in Cotton Petroleum Corp. v. New Mexico, 490 U.S. 163, 194 (1989) (Blackmun, J., dissenting) ("The 1938 Act is silent on the question of state taxation."); California Cigarette Tax, CAL. Rev. \& TAX. Code § 30107 (Vest 1979), cited in California State Bd. of Equalization v. Chemehuevi Indian Tribe, 474 U.S. 9, 10 (1985) ("California's cigarette tax statute "does not contain any . . explicit "pass through" language'....").

76. McClanahan, 411 U.S. at 171.

77. See CoHEN (1982), supra note 2, at 180-206. 
efforts at community building by federal programs undertaken as part of President Lyndon Johnson's "Great Society."78 Tribal sovereignty was given a further boost by the self-determination policy embraced by the Nixon Administration, and by congressional legislation and policies encouraging fuller exercise of tribal governance. ${ }^{79}$ In some areas, such as child custody, Congress substantially expanded tribal powers. ${ }^{80}$

However, the modern-era cases, from Williams (1959) through McClanahan (1973) and on into the decisions of the early 1980s, exerted the most important influence in the revival of tribal governing powers. A host of major decisions based on foundation principles limited the scope of state law and upheld the authority of tribes to govern activity within Indian country. ${ }^{81}$ This encouraged nascent tribal leadership to assert powers of self-government to improve reservation economic and social conditions. The Court reaffirmed what had been cast into doubt by the practical expansion of state authority onto reservations: that reservations remained under the governance of tribes, largely to the exclusion of state law. This was the assurance many tribes needed to take greater control of their own destinies.

The Court's recognition of the immunity of reservation activity from state taxes and regulation and of commensurate tribal authority over the same subject matter supported tribal economic development initiatives. Tribes launched programs to tax mineral production, promote tourism, sell hunting and fishing licenses, operate bingo games, and profit from the sale of items such as cigarettes that are heavily taxed by states off the reservation. Billions of dollars a year now flow onto reservations thanks to judicial decisions recognizing Indian rights, espe-

78. Leadership opportunities were provided in community aetion programs under which people were organized and federally funded programs carried out. Indians also became eligible under these programs for economic assistance in the form of loans, grants, low-rent housing, job training, education, and other services. See CoHEN (1982), supra note 2, at 188-90.

79. President Nixon said in 1970: "The time has come to break decisively with the past and to create the conditions for a new era in which the Indian future is determined by Indian acts and Indian decisions." H.R. Doc. No. 363, 91st Cong., 2d Sess. I (1970). Congress responded to the President's charge with the Indian Education Act of 1972, codified in scattered sections of 20 U.S.C. (rcpealed 1988); the Indian Financing Act of 1974, 25 U.S.C. $\$ \$ 145 I-I 544$; the Indian Self-Determination and Education Assistance Act of 1975,25 U.S.C. $\S \S 450-450 \mathrm{n}$; and the American Indian Religious Freedom Act of 1978, 42 U.S.C. $\$ 1996$.

80. For example, the Indian Child Welfare Act of 1978, 25 U.S.C. $\$ \$ 1901-1963$ (1994), goes beyond affirming inherent tribal powers as recognized by the courts, see e.g., Fisher v. District Court, 424 U.S. 382 (1976), and grants tribal jurisdiction over placement of any child who resides within the reservation or is a ward of the tribe, and requires state courts to transfer jurisdiction over any Indian child not residing on the reservation to tribal court on petition of either parent or the tribc. Congress has so strongly endorsed tribal authority over such cases that it has effectively displaccd the bestinterests-of-the-child test prevalent in state courts. HOMER H. Clark, JR., THE LAW OF DOMESTiC Relations in the UNITEd States $\$ 20.1$ (Practitioner's Edition, 2d ed. 1987).

81. See WILKINSON, supra note 3 , at 89-93. 
cially rights to control and tax activities on the reservation to the exclusion of state law.

As tribes were gaining in the scope of their legal authority, tribal land ownership also grew by sixteen million acres from 1970 to $1992 .^{82}$ Although tribal landholdings are still less than they were before the allotment policy of the late-nineteenth century took effect, the dispossession trend has been reversed. ${ }^{83}$ Furthermore, rapid growth of tribal populations has brought ever-growing numbers of people under tribal governing authority. ${ }^{84}$

The growth of population and business activity on reservations has led to a need for better administration of justice, including regulation, civil adjudication, and taxation to support government services. Most tribes historically maintained largely informal structures for dispute resolution. Today, formalized adjudication predominates, and tribal courts operate on at least 172 reservations. ${ }^{85}$ A vacuum created by inadequate federal law enforcement on reservations has increasingly been filled by the tribes themselves. ${ }^{86}$

82. See Facsimile from Stuart Ott, Office of Trust Responsibilities, Bureau of Indian Affairs, U.S. Dep't of Interior, to the author (Apr. 4, 1995) (on file with author).

83. In 1955, total tribal holdings reached a low of 407.9 million acres. Since that time, the amount of Indian land has fluctuated, generally rising, and now exceeds 700 million acres. See Census Bureau, U.S. Def'T of Commerce, Statistical AbSTract of the United States 237 (101st ed. I980).

84. Indian populations have grown dramatically since the middle of the twentieth century. Some of this growth can be attributed to changes in blood quantum criteria defining who is a tribal member. But most of the increase is due to high fertility, which is the norm for Indian populations across the country. In 1992, the birth rate per 1,000 women was 75 for American Indians but 67 for whites. See Census Bureau, U.S. Dep't of Commerce, STatistical Abstract of the United States 74 (115th ed. 1995); see also Harold L. Hodgkinson et al., The Demographics of AMERICAN INDIANS (1990).

85. Of the $\mathbf{1 7 2}$ tribal courts in existence today, 21 are still based on Code of Federal Regulation (C.F.R.) guidelines. See Telephone Interview with Elbridge Coochise, President of the National American Indian Court Judges Association (June 3, 1994). It is estimated that over $\$ 80$ million would be required to run the courts effectively: $\$ 250,000$ for each court's judge, clerks, and support staff. Prior to 1994 , only $\$ 14$ million was allocated to run the 172 courts. Id. Legislation passed on December 3, 1993, earmarked $\$ 50$ million annually for the courts. Indian Tribal Justice Act of 1993 , Pub. L. No. 103-176, 107 Stat. 2004. See also National Am. INDIAN CouRT Judges Ass'N, Indian COURTS AND THE FUTURE 8 (I978).

86. "[F]ederal law enforcement on reservations is often selective, if not indifferent. [It] appears to have improved hittle since the early 1980s, when the chairman of the United States Commission on Civil Rights described it as being characterized by inaction and missed opportunities."' Mary C. Gordon, Note, United States v. Alvarez-Machain: An Unexpected Ally for Native American Tribal Authority, I993 UTAH L. REv. 875, 890-91 (1993) (footnotes ommitted). 
II

\section{ENCROACHMENT OF JUdiCIAL SUBJECTIVISM on Foundation Principles}

The modern era of Indian law jurisprudence has ended. The new tendency in the Court's tests, rules, and rhetoric is to define tribal powers according to policies, values, and assumptions prevalent in nonIndian society. Past judicial decisions led to broader exercises of tribal governance. But as tribal assertions of jurisdiction became more extensive, the Court started to retreat from its modern-era affirmations of unextinguished tribal powers, altering the margins of the tribes' jurisdiction in order to preserve the values and interests of the larger society. These judicial attempts to anticipate and alleviate cultural conflict have succeeded in curbing the authority of tribal institutions whose actions appear to encroach upon the property interests or values of nonIndians. This subjectivist trend began with cases involving non-Indian parties or property, but the Court's search for the desirable "current state of affairs" has not been confined to such cases. The Justices have also begun to restate jurisdictional principles to suit non-Indian cultural norms in cases that primarily affect Indians.

Without explicitly overruling precedent, the current Court has failed to reconcile results with foundation principles long adhered to by the Supreme Court itself, principles that generally require congressional action to limit tribal sovereignty. ${ }^{87}$ In at least seventeen decisions since 1980 , the Supreme Court has marked out the boundaries of Indian selfgovernment, arguably pursuing its own notion of what is desirable instead of being disciplined by established tests and rules. ${ }^{88}$ These cases have ignored guidelines for construing treaties ${ }^{89}$ which were designed,

87. In earlier times, even cases allowing destruction of tribal rights and powers were usually based on deference to exercises of congressional power. See Lone Wolf v. Hitchcock, 187 U.S. 553, 566 (1903); United States v. Kagama, 118 U.S. 375, 382 (1886).

88. Okla. Tax Comm'n v. Chickasaw Nation, 115 S. Ct. 2214 (1995); Department of Taxation \& Fin. v. Milhelm Attea \& Bros., 114 S. Ct. 2028 (1994); Hagen v. Utah, 510 U.S. 399 (1994); South Dakota v. Bourland, 508 U.S. 679 (1993); County of Yakima v. Confederated Tribes \& Bands of Yakima Indian Nation, 502 U.S. 251 (1992); Blatchford v. Native Village of Noatak, 501 U.S. 775 (1991); Okla. Tax Comm'n v. Citizen Band Potawatomi Indian Tribe, 498 U.S. 505 (1991); Duro v. Reina, 495 U.S. 676 (1990); Employment Div., Dep't of Human Resources v. Smith, 494 U.S. 872 (1990); Brendale v. Confederated Tribes \& Bands of Yakima Indian Nation, 492 U.S. 408 (1989); Cotton Petroleum Corp. v. New Mexico, 490 U.S. 163 (1989); Lyng v. Northwest Indian Cemetery Protective Ass'n, 485 U.S. 439 (1988); California v. Cabazon Band of Mission Indians, 480 U.S. 202 (1987); United States v. Dion, 476 U.S. 734 (1986); Rice v. Rehner, 463 U.S. 713 (1983); Montana v. United States, 450 U.S. 544 (1981); Washington v. Confederated Tribes of Colville Indian Reservation, 447 U.S. 134 (1980).

89. The Court had consistently interpreted treaties liberally in favor of the Indians: "[D]oubtful expressions are to be resolved in favor of the weak and defenseless people who are the wards of the nation, dependent upon its protection and good faith." McClanahan v. Ariz. State Tax Comm'n, 411 U.S. 164, 174 (1973) (quoting Carpenter v. Shaw, 280 U.S. 363, 367 (1930)). See also Choctaw Nation v. United States, 119 U.S. 1, 27-28 (1886); Worcester v. Georgia, 31 U.S. (6 Pet.) 515, 582 
after all, to make reservations permanent enclaves where Indians could exist relatively free of non-Indian control..$^{90}$ This subjectivist trend has its roots in a series of cases decided between 1978 and 1989.

\section{A. Pivotal Decisions in the Court's Retreat from Foundation Principles}

Four internally contentious decisions over an eleven-year period mark the origins of the Court's departure from the tradition of judicial respect for tribal sovereignty. ${ }^{91}$ This movement is what Justice Scalia described with apparent resignation in his internal memorandum to Justice Brennan. ${ }^{92}$ The Court's subjectivism has created a treacherous undertow, pulling tribes into the societal mainstream and straining the indigenons cultural bonds that hold them together as societies. ${ }^{93}$

\section{Oliphant v. Suquamish Indian Tribe}

Oliphant ruled that tribal authorities lack jurisdiction to try and punish non-Indians for crimes committed on reservations. The decision represents a sharp departure from foundation principles. Until Oliphant, the only two "inherent limitations" on tribal sovereignty that the Court had recognized were those concerning dealings with foreign nations and extinguishinent of land titles. These two exceptions, created

(1832) ("The language used in treaties with the Indians should never be construed to their prejudice."). Additionally, the Court construes treaties "in the sense in which they would naturally be understood by the Indians." Jones v. Meehan, 175 U.S. 1, 11 (1899); see also Washington v. Wash. State Commercial Passenger Fishing Vessel Ass'n, 443 U.S. 658, 676 (1979); United States v. Winans, 198 U.S. 371, 380-81 (1905).

90. Treaties typically secured the tribes "a permanent home and abiding place" where they would have "absolute and undisturbed use and occupation," promising that non-Indians would never be permitted to settle on the reservation. See, e.g., Treaty with the Eastern Band Shoshoni and Bannock, July 3, 1868, 15 Stat. 673, reprinted in 2 Indan Affalrs: Laws and Treaties 1020-23 (Charles J. Kappler ed., 1904) [hereinafter 2 INDIAN AFFAlRs] ("set apart for the absolute and undisturbed use and occupation... and the United States now solemnly agrees that no persons ... shall ever be permitted to pass over, settle upon, or reside in [that territory]"); Treaty with the Sioux and Arapaho, April 29, 1868, 15 Stat. 635, reprinted in 2 INDIAN AFFAIRs, supra, at 9981003 ("set apart for the absolute and undisturbed use and occupation"); Treaty with the Yakima, June 9, 1855, 12 Stat. 951, reprinted in 2 INDIAN AFFAIRS, supra, at 698-702 ("set apart... for the exclusive use and benefit").

91. Brendale v. Confederated Tribes \& Bands of Yakima Indian Nation, 492 U.S. 408 (1989); Montana v. United States, 450 U.S. 544 (1981); Washington v. Confederated Tribes of Colville Indian Reservation, 447 U.S. 134 (1980); Oliphant v. Suquamish Indian Tribe, 435 U.S. 191 (1978).

92. See supra note 4 and accompanying text.

93. The powerful effect of law, particularly rules of jurisdiction, on the survival and integrity of Indian tribal cultures (as well as on our national quality of life) is richly elucidated by Professor Pommersheim. Frank Pommershelm, Brald of Feathers: AMERICAN INDIAN LAW aNd Contemporary Tribal LIFE (1995). 
in the early cases, were justified by the so-called "discovery doctrine." The United States succeeded not only to the territory of its European predecessors but to sovereign prerogatives defined by this essentially colonial theory. The discovery doctrine was necessary to nullify dealings by the tribes with rival colonizing nations or subjects that could jeopardize the Europeans' political dominion over the territory they claimed.95 They helped secure the overriding sovereignty of the young United States by guaranteeing that territory occupied by the tribes would not be transferred to foreign powers.

The new "inherent limitation" on tribal sovereignty discovered in Oliphant was ostensibly based on the nation's interest in protecting personal liberty by controlling the manner in which criminal cases are tried. Justice Rehnquist argued for the majority that just as the United States has a sovereign interest in "[p]rotection of territory within its external political boundaries," so it "has manifested an equally great solicitude that its citizens be protected ... from unwarranted intrusions on their personal liberty."96 From an historical perspective, these two interests do not compare. ${ }^{97}$ When Chief Justice Marshall crafted his two ex-

94. See Worcester v. Georgia, 31 U.S. (6 Pet.) 515, 543-44 (1832); Johnson v. McIntosh, 21 U.S. (8 Wheat.) 543, 570 (1870). For a discussion of the "discovery doctrine," see supra notes 15-25 and accompanying text.

95. In adopting the discovery doctrine, Chief Justice Marshall recognized that the tribes' "rights to complete sovereignty, as independent nations, were necessarily diminished." Jolmson, 21 U.S. at 574.

96. Oliphant, 435 U.S. at 209-10.

97. Certainly at the time of the Indian tribes' absorption into the United States, the national government's solicitude for individual liberties was not so great as its concern for the conduct of foreign relations and the integrity of its borders. In fact, state governments were wholly unconstrained by the constitutional guarantee of due process until the adoption of the Fourteenth Amendment in 1868, and the courts did not finish applying the Bill of Rights uniformly to state actions until a century Iater. See Duncan v. Louisiana, 39I U.S. 145 (1968) (applying the Sixth Amendment's right to jury trial in criminal cases to the states).

These incorporation cases defined whether "a particular procedure is fundamental ... to an Anglo-American regime of ordered liberty." Id. at 149 n.14. Obviously, all criminal prosecutions in state courts were not barred whenever those tribunals declined to enforce the Bill of Rights. Even today some protections in the first ten Amendments are not guaranteed against the states. LAURENCE H. Tribe, American Constitutional Law \& 1I-2, at 772 (2d ed. 1988) (noting that full incorporation of the Bill of Rights has never commanded a Court majority).

Even if the national government had made more stringent demands on the states to protect individual liberties in criminal trials, the Supreme Court had long ago mooted consideration of incorporating constitutional rights within Indian tribunals by declaring tribal sovereignty independent of and precedent to the United States Constitution. Talton v. Mayes, 163 U.S. 376, 384 (1896) (holding that the Fifth Amendment does not apply to tribal governments). Though the Court has never overruled this exemption, it later characterized Oliphant as barring "prosecut[ion of] non-Indians in tribal courts which do not accord the full protections of the Bill of Rights." Washington $v$. Confederated Tribes of Colville Indian Reservation, 447 U.S. 134, I53-54 (1980). Not until 1968 were tribal authorities made subject to many of the safeguards in the Bill of Rights by the Indian Civil Rights Act of 1968, 25 U.S.C. $\S 1302$.

Congress has selectively applied federal criminal laws to reservations. See, e.g., Indian Country Crimes Act, I8 U.S.C. § 1152; Major Crimes Act of 1885, 18 U.S.C. § I153. Other laws permitted 
ceptions to tribal sovereignty, the possibility that Indians would convey land to foreign nations or subjects formed a palpable threat to the integrity of the young nation. The potential for individual violations of civil liberties by tribes was not then and is not now a similar threat to national security. Furthermore, the suggestion that tribal exercise of criminal jurisdiction will subject non-Indian defendants to unfair process is unsupported by the facts. ${ }^{98}$

The Oliphant Court justified its intrusion on tribal sovereignty as consistent with historical expectations. Justice Rehnquist referred to a "commonly shared presumption of Congress, the Executive Branch, and lower federal courts that tribal courts do not have the power to try non-Indians." 99 He cited mostly fragments of historical evidence as support. Oliphant's only legal citations are to statutes not applicable to the facts of the case, contradictory opinions of executive branch officers, congressional reports on tangentially related legislation, and an 1878 decision by a maverick district judge. ${ }^{100}$ What is most remarkable, though, is not the thin historical record on which the Court relied; rather, it is the fact that conjectures about the past were used to justify a legal principle fixing the limits of tribal sovereignty. Nowhere does the Court explain why popular assumptions about tribes' criminal jurisdiction should override the foundation principles' guarantee that Indian autonomy will be curbed only at the direction of Congress.

Oliphant came as a surprise to many. Congress had yet to address directly the question of tribal criminal jurisdiction over non-Indians. ${ }^{101}$

state jurisdiction over certain reservations in certain states. See 18 U.S.C. $\$ 1162(a)$ (1994) (listing reservations where state authorities will have jurisdiction over criminal offenses); 28 U.S.C. $\S$ 1360(a) (1994) (same for civil actions); see also supra text accompanying note 65 . At most, these laws show Congress' capacity to respond to concerns about how justice should be administered in Indian country.

98. In Oliphant, the record did not reflect any pattern of discrimination or abuse of the rights of non-Indians. The majority conceded that "Indian tribal court systems have become increasingly sophisticated and resemble in many respects their state counterparts." Oliphant, 435 U.S. at 211-12. "[W]ith the passage of the Indian Civil Rights Act of 1968, which extends certain basic procedural rights to anyone tried in Indian tribal court, many of the dangers that might have accompanied the exercise by tribal courts of criminal jurisdiction over non-Indians only a few decades ago have disappeared." Id. at 212. No specific violation of that Act was alleged in Oliphant. One defendant had been arrested for assaulting a tribal police officer; the other had ended a high-speed chase with tribal officers by crashing into a tribal pohice car. Id. at 194.

99. Id. at 206.

100. Id. at 198-206. The Court's rendition of history probably is accurate in one respect: it is doubtful that nineteenth-century Americans believed that tribes could punish non-lndians for crimes committed in Indian country. See Richard B. Collins, Implied Limitations on the Jurisdiction of Indian Tribes, 54 WAsH. L. REv. 479, 501-02, 506 (1979) (concluding that it was probably commonly assumed that tribes could not punish non-Indians who were on the reservation under U.S. authority or even as intruders, except where treaties provided otherwise, but that assumption likely did not extend to non-Indians who voluntarily joined tribal societies).

101. Congress made crimes between Indians and non-Indians subject to federal jurisdiction, but did not address tribal jurisdiction except to exclude "any Indian committing any offense in the Indian 
Never before had the Court acted unilaterally to extend the "inherent limitations" on tribal sovereignty staked out in the foundation cases. In a one-paragraph dissent, Justice Marshall, joined by Chief Justice Burger complained that only a treaty or act of Congress could divest the tribes of a "necessary aspect of their retained sovereignty."102

Oliphant has been widely criticized. ${ }^{103}$ Its ruling, however, has not been terribly disruptive of Indian governments; tribal exercises of criminal jurisdiction over non-Indians have been relatively rare and recent. Since the rationale for limiting tribal sovereignty to protect the civil liberties of non-Indians is a relatively narrow one, it appears to affect only criminal punishments. Indeed, the Oliphant Court was careful to state that its ruling restricted only tribal criminal jurisdiction, ${ }^{104}$ leaving untouched the tribes' far more important civil jurisdiction over nonIndians.

Oliphant's impact was also tempered because it came on the heels of several Supreme Court decisions that powerfully reaffirmed the inherent sovereignty of Indian tribes. Fisher v. District Court, ${ }^{105}$ a per curiam opinion, resoundingly upheld tribal courts' exclusive jurisdiction over adoption proceedings in which all of the parties are tribal members living on the reservation. In Bryan v. Itasca County, ${ }^{106}$ a unanimous Court rejected Minnesota's attempt to impose property taxes on reservation mobile homes. The state staked its position on Public Law 280's authorization for the exercise of jurisdiction in Indian country over "civil causes of action... and those civil laws ... of general application to private persons or private property."107 The Court held that the law was not specific enough to grant states authority to tax Indians or Indian property on the reservation. ${ }^{108}$ Fisher and Bryan bolstered the

country who has been punished by the local law of the tribe." Indian Country Crimes Act, 18 U.S.C. $\S 1152$ (1994). For a discussion of $M c B$ ratney's limits on tribal jurisdiction ovcr reservation crimes among whites, see supra notes 50-52 and accompanying text.

102. Oliphant, 435 U.S. at 212 (Marshall, J., dissenting).

103. See, e.g., Russel L. Barsh \& James Y. Henderson, The Betrayal: Oliphant v. Suquamish Indian Tribe and the Hunting of the Snark, 63 MiNN. L. Rev. 609, 610 (1979) (arguing that the Court "reveals a carelessness with history, logic, precedent, and statutory construction that is not ordinarily acceptable"); Peter C. Maxfield, Oliphant v. Suquamish Tribe: The Whole is Greater than the Sum of the Parts, 19 J. ConTEMP. L. 391, 396 (1993) (characterizing the justification the Court used to reach its result in Oliphant as "reprehensible"); Williams, The Algebra of Indian Law, supra note 21, at 273 (criticizing Oliphant's "near-theological totalization of a desacralized modem body politic"); Kevin Meisner, Comment, Modern Problems of Criminal Jurisdiction in Indian Country, 17 AM. INDIAN L REv. 175, 191-93 (1992) (arguing that Oliphant failed to construe statutes in favor of Indians).

104. Oliphant, 435 U.S. at 196 n.7.

105. 424 U.S. $382(1976)$.

106. 426 U.S. 373 (1976).

107. Id. at 377 (quoting 28 U.S.C. $\$ 1360($ a)) (internal quotations omitted).

108. See id. at 381, 392-93. 
effect of the $1973 \mathrm{Mc}$ Clanahan decision, ${ }^{109}$ illustrating that although Worcester's categorical exclusion of state jurisdiction had been modified in some circumstances, ${ }^{110}$ the preemption doctrine would resolve most matters against the states.

Oliphant was further isolated by two other Indian sovereignty cases from the 1977 term. United States $v$. Wheeler, ${ }^{111}$ decided just two weeks later, was full of strong declarations of tribal sovereignty and citations to Worcester and the work of Felix Cohen. Wheeler held that an Indian subject to successive tribal and federal criminal prosecutions could not claim double jeopardy because the tribe had "inherent powers of a limited sovereignty which has never been extinguished." 112 Wheeler was followed by Santa Clara Pueblo v. Martinez, ${ }^{113}$ which underscored the tribes' status as "separate sovereigns pre-existing the Constitution" that had "power to make their own substantive law."114 That decision rejected an equal protection challenge to a tribal membership ordinance curtailing benefits to children of women, but not men, who married outside the tribe. The Court held that gender distinctions drawn by tribal authorities do not raise Fourteenth Amendment concerns because "tribes have historically been regarded as unconstrained by those constitutional provisions framed specifically as limitations on federal or state authority."115

In Oliphant, by contrast, the Court found the national interest in protecting civil rights so great that tribes necessarily lost their criminal jurisdiction over non-Indians. The disparity between Oliphant and other cases from the era appears to be the product of the Court's concern for protecting non-Indian interests. When a case did not involve the liberty or property of non-Indians, tribal sovereignty was upheld. The Court's preoccupation with safeguarding non-Indian values seems exaggerated, however, given Congress' plenary power over the tribes. When in the past tribal exercises of jurisdiction have threatened nonIndian values, Congress has responded. ${ }^{116}$

109. 411 U.S. at $179-81$ (reaffirming foundation principles in a modern context by denying states power to tax reservation-generated income of Indians).

110. See supra Part I.B.

111. 435 U.S. 313 (1978).

112. Id. at 322 (quoting CoHEN (1941), supra note I, at 122).

113. 436 U.S. 49 (1978).

114. Id. at 55-56.

115. Id. at 56.

116. See Assimilative Crimes Act of 1948, 18 U.S.C. $\$ 13$; Major Crimes Act of 1885,18 U.S.C. $\S$ I153; Indian Civil Rights Act of 1968, 25 U.S.C. $\$ \S 1301-1303$; Indian Gaming Regulatory Act of 1988, 25 U.S.C. $\$ \S 2701-2721$. 
2. Washington v. Confederated Tribes of the Colville Indian Reservation

A major milestone along the path to judicial subjectivism was Washington $v$. Confederated Tribes of the Colville Indian Reservation, ${ }^{117}$ which allowed the state to tax sales of cigarettes on the reservation to non-members of the tribe. The case was a more significant blow to tribal autonomy than Oliphant. It seriously undermined tribal efforts at achieving economic self-sufficiency by curbing the burgeoning growth of reservation businesses unburdened by state taxes.

In the 1970s, tribes throughout the country began to make use of McClanahan's affirmation that reservation activities were not subject to state taxation. The viability of reservation businesses had historically been frustrated by their locations, typically far from transportation and commercial centers, and by the absence of a trained work force. But when the tribes established their own enterprises and took advantage of their immunity from state tax, they began to break a near-perfect chain of failed federal economic development efforts. Tribes imposed their own taxes on reservation businesses, finely tuning the taxation scheme to preserve the economic advantage of freedom from state and local taxes. The most rewarding businesses were those whose products were typically subject to high state taxes-cigarettes, liquor, and fireworks. Cigarette sales were especially attractive because of potentially high volumes, a large ratio of taxes to wholesale price, and relatively low regulatory burdens. "Smokeshops" run by enterprising tribal members popped up on many reservations.

States reacted aggressively to recover the taxes they were losing to the reservations' tax-exempt sales. ${ }^{118}$ When Montana authorities arrested an Indian smokeshop owner in 1972 on the Flathead Reservation for selling unstamped (untaxed) cigarettes, the merchant and the tribe brought a federal action challenging the state's jurisdiction. A unanimous decision by Justice Rehnquist in Moe v. Confederated Salish \& Kootenai Tribes ${ }^{119}$ relied on McClanahan to affirm a lower court ruling that reservation cigarette sales to Indians were not subject to state tax.

Rehnquist added a passage, however, stating that Montana could tax sales to non-Indians. ${ }^{120}$ He deferred to a presumption in the Montana

117. 447 U.S. 134 (1980).

118. See, e.g., Moses v. Kinnear, 490 F.2d 21 (9th Cir. 1973); Walker River Paiute Tribe v. Sheehan, 370 F. Supp. 816 (D. Nev. 1973); Mahoney v. State, 524 P.2d 187 (Idaho 1973); Tonasket v. State, 525 P.2d 744 (Wash. 1974).

119. 425 U.S. 463, 480-81 (1976), aff'g 392 F. Supp. 1297 (D. Mont. 1974), and 392 F. Supp. 1325 (D. Mont. 1975).

120. See Moe, 425 U.S. at 481-83. Rehnquist went on to say that the State could require the Indian merchant to collect the tax. He found that imposing such a duty on Indians was the only way to ensure that a non-Indian purchaser would not "flout $h i s$ legal obligation to pay the tax," id. at 482, 
law that the tax falls on the retail consumer, and thereby avoided looking at the realities of the tax's impact on the tribe. ${ }^{121}$ The state's jurisdiction to impose the tax came through this loophole. The issue of taxation of reservation sales to non-Indians was of paramount importance to the parties. Opportunities for major profit-making by reservation smokeshops came from sales to non-Indians who lived on or near the reservation or who were willing to make the trip for the lower price. Tax-exempt sales of tobacco to Indians alone would not have justified setting up smokeshops.

Amidst a line of cases supportive of tribal government, Moe's decision on non-Indian taxation seemed to create only a narrow and distinguishable exception rooted in the technical language of a state law. ${ }^{122}$ And it left open the possibility that a tribe could rebut a state law presumption that the tax falls on the consumer by producing a factual record demonstrating the actual economic impact of a state cigarette tax on tribal government. ${ }^{123}$ Perhaps if the tribe's interest in self-government were more substantially affected by the tax or if federal interests expressed in statutes and policies were implicated, the result in another case might be different. Several tribes restructured their operations, making it easier to demonstrate the impact of state taxation. A few ran their own cigarette businesses, which would directly feel the loss of revenues from sales to non-Indians. Others made the tribe the intermediary in tobacco sales, either buying the cigarettes and having merchants sell the then-Indian-owned and -taxed cigarettes, or simply acting as a wholesaler to individual tribal entrepreneurs.

and that it imposed but a "minimal burden" on the Indian seller, id. at 483 . As to non-Indians, Rehnquist did not attempt to apply or distinguish $M c$ Clanahan or to fit the case into the exception allowing taxation of non-Indians in Indian country only where it would not affect Indians. See sources cited supra note 58. He cited Thomas v. Gay without discussing that factor. See Moe, 425 U.S. at 483. He did distinguish Warren Trading Post Co. v. Ariz. State Tax Comm'n, 380 U.S. 685 (1965) (disallowing state gross receipts tax on reservation merchants), on the ground that the tax in that case fell on sales to Indians. Moe, 425 U.S. at 482 . Rehnquist also distinguished Williams v. Lee, 358 U.S. 217, 219-20 (1959) (denying state court jurisdiction over non-Indian reservation merchant's suit against Indian debtor), as concemed only with tribal self-government, apparently presuming that the burden of tax collection would not raise such concerns. Moe, 425 U.S. at 483 .

121. See Moe, 425 U.S. at $481-82$. The Court was of course free to determine for itself where the burden of the tax fell. Cf. First Agric. Nat'l Bank v. State Tax Comm'n, 392 U.S. 339, 347 (1968) (holding that the Court is not bound by a state's characterization of its tax).

122. An Indian law casebook from the era characterized Moe as follows: "[S]ince Williams was decided in 1959, the Court has approved state jurisdiction in Indian country only once. That was in the limited context of Moe v. Confederated Salish \& Kootenai Tribes ...." DAvid H. GETCHES ET aL., CASES and Materials on Federal Indian Law 297 (1979).

123. The impropriety of the Court's uncritically relying on a state's characterization of an economic transaction, as well as flaws in Moe's analysis of the economic impacts of the cigarette tax, are fully discussed in Russel L. Barsh, The Omen: Three Affiliated Tribes v. Moe and the Future of Tribal Self-Government, 5 AM. INDIAN L. REV. 1, 28-37 (1977). 
Tribes in the State of Washington had pursued schemes under which they profited from cigarette sales, by regulating wholesale transactions and taxing sales to the consumer. When the state seized cigarette shipments destined for four reservations where they were to be sold free of state tobacco and sales taxes, the tribes sued. ${ }^{124}$ Lower court proceedings were stayed for several months to await the Court's decision in Moe, which resolved most of the key questions. The parties and the lower court then focused on whether the Colville tribes' interests were adequately implicated in the tobacco sales to distinguish the case from Moe. The three-judge district court found that they were, ruling that the state taxes could not be applied to any reservation sales. ${ }^{125}$

The Supreme Court reversed, rejecting the lower court's effort to distinguish the case from Moe. It allowed the state to impose its tax notwithstanding the existence of a lawful tribal taxing scheme applicable to non-Indians. ${ }^{126}$ Neither the tribal tax nor the tribe's economic stake in tobacco sales convinced the Court that federal law preempted the tax or that Indian self-government would be infringed.

The Colville Court did not reach its decision easily. The case was vigorously debated in the Court's chambers from almost the opening day of the 1979 Term until its close in June, 1980. Although six Justices signed the majority decision upholding state power to tax reservation cigarette sales, and Justice Stewart's opinion appears in partial agreement, the Court came close to reaching the opposite result. Justice Brennan had drafted an opinion for what was thought to be a majority of the Court that denied the state's power to tax reservation cigarette sales. ${ }^{127}$ Brennan spent several months revising his opinion to address issues raised by ostensible allies. Meanwhile, Justices Stevens and Rehnquist wrote separate dissents, Justice White said he would probably join Stevens, and Justice Stewart submitted an opinion partially concurring and partially dissenting.

124. Confederated Tribes of Colville Indian Reservation v. Washington, 446 F. Supp. 1339 (E.D. Wash. 1978), aff'd in part and rev'd in part, 447 U.S. I34 (I980).

125. Id. at 1361-62, 137I. An issue on appeal became the legality of the tribal tax on non-indian sales. Oliphant had come down just before the district court decision, leaving open the question of tribal civil jurisdiction over non-Indians. Extending Oliphant's denial of tribal criminal authority over non-Indians to civil jurisdiction would have barred tribes from taxing non-Indians and required reversal of the district court. As it turned out, the Colville Court refused to extend Oliphant, and so the tribes won the most important legal point by having their taxes validated. See Colville, 447 U.S. at 153.

126. Colville, 447 U.S. at I58-59.

127. First Draft Opinion of Justice William J. Brennan, Jr., Washington v. Confederated Tribes of Colville Indian Reservation, No. 78-630, at 22 (Nov. 26, 1979) thereinafter First Draft Colville Opinion], in Papers of Justice William J. Brennan, Jr. (reproduced from the Collections of the Manuscript Division, Library of Congress) (on file with author) [hereinafter Brennan Papers]. 
Brennan then wrote a memorandum to his colleagues in an effort, as he put it, "to bring things to a head." 128 His goal was to straighten out collateral issues on which there were sharp differences with the dissenters. It appeared there still were five votes for his key holding that the state cigarette tax could not be applied to any reservation sales. $\mathrm{He}$ offered to alter the part of his decision that also invalidated a separate state sales tax. ${ }^{129}$

A surprise came in the response from Chief Justice Burger, who suggested that he was no longer inclined to join the Brennan opinion. ${ }^{130}$ Brennan then asked the Chief Justice to reassign the opinion, since he lacked five votes without Burger. ${ }^{131}$ The case was assigned to Justice White, who adopted almost verbatim the portions of Brennan's draft opinion dealing with matters other than the cigarette $\operatorname{tax}^{132}$ Justice

128. Memorandum from Justice William J. Brennan, Jr. to the Conference 1 (Jan. 14, 1980) (Washington v. Confederated Tribes of Colville Indian Reservation, No. 78-630) [hereinafter Brennan Colville Memo], in Brennan Papers, supra note 127.

129. Id. at 3. Justice Powell disagreed with that part of the opinion. The parties had not foreseen that the sales tax might be treated differently from the cigarette tax; it had not been raised as a separate issue on appeal. Brennan also wrote that Indians on a reservation who are not members of the tribe should be treated the same as members for tax purposes. First Draft Colville Opinion, supra note $\mathrm{I} 27$, at 25. He hinted he was willing to vary that position as well. Brennan Colville Memo, supra note $\mathrm{I} 28$, at 4 .

130. When Chief Justice Burger assigned the majority opinion to Justice Brennan, he indicated that, except for a jurisdictional issue, "my vote was the same as yours," and on the jurisdictional issue, "I'm prepared to go along." Memorandum from the Chief Justice to Justice William J. Brennan, Jr. (Oct. I5, 1979) (Washington v. Confederated Tribes of Colville Indian Reservation, No. 78-630), in Brennan Papers, supra note I27.

However, in his response to Brennan's memorandum, Burger later wrote:

Dear Bill:

In reviewing our "inventory" before taking off for the Mid-Year ABA session, I find [this case].

I will await word from you as to anything you want me to do-other than join you!

$$
\text { Regards, }
$$

WEB

Memorandum from the Chief Justice to Justice William J. Brennan, Jr. (Feb. 1, I980) (Washington v. Confederated Tribes of Colville Indian Reservation, No. 78-630), in Brennan Papers, supra note 127.

131. Memorandum from Justice William J. Brennan, Jr. to the Chief Justice (Feb. 4, 1980) (Washington v. Confederated Tribes of Colville Indian Reservation, No. 78-630), in Brennan Papers, supra note I27. The letter began, "Assuming that your memorandum of last Friday constitutes a vote against my position in the above [case], I offer the following score sheet..." Id. Chief Justice Burger wrote back three weeks later to confirm that "I cannot join your opinion in this case." Memorandum from the Chief Justice to Justice William J. Brennan, Jr. (Feb. 25, 1980) (Washington v. Confederated Tribes of Colville Indian Reservation, No. 78-630), in Brennan Papers, supra note 127.

132. The points on which a majority effectively adopted Brennan's draft opinion were that (I) the Supreme Court had appellate jurisdiction over the three-judge district court decision, Colville, 447 U.S. at 145-49; First Draft Colville Opinion, supra note I27, at 7-12; (2) Washington's excise tax on motor vehicles and mobile homes owned by tribal members was invalid, Colville, 447 U.S. at I62-64; First Draft Colville Opinion, supra note I27, at 23-24; (3) the State's assumption of jurisdiction over the reservations was governed by an intervening Supreme Court decision, Colville, 447 U.S. at 164; First Draft Colville Opinion, supra note 127, at 26; and (4) tribes generally have power to impose taxes on non-Indians within the reservation, Colville, 447 U.S. at I50-59; First Draft Colville Opinion, supra note 127 , at $15-22$. 
Brennan turned the remainder of his draft into a dissent which only Justice Marshall joined. ${ }^{133}$ Justices Powell and Blackmun (who had been wavering) switched to the majority, while Justice Stewart stuck with his opinion, concurring in part and dissenting in part.

Justice White's majority opinion dealt with preemption in a conclusory way. It took him less than a page to dismiss five federal statutes and several treaties alleged to be in conflict with the state's taxation of reservation sales. The gist of the decision was that the tribe should not be able to use its sovereign status to its economic advantage: "We do not believe that principles of federal Indian law, whether stated in terms of pre-emption, tribal self-government, or otherwise, authorize Indian tribes thus to market an exemption from state taxation to persons who would normally do their business elsewhere." ${ }^{\text {"134 }}$

Justice Brennan's dissent applied the preemption analysis emerging in other cases of the era. He described the Indian sovereignty doctrine as resulting from "an intricate web of sources including federal treaties and statutes, the broad policies that underlie those federal enactments, and a presumption of sovereignty or autonomy that has roots deep in aboriginal independence." 135 The two most important federal policies in Colville, he argued, were encouragement of tribal self-government and stimulation of Indian economic development. He cited supportive hortatory language in several federal statutes, indicators that the majority found unpersuasive. The upshot of Brennan's argument was that congressional policy favored treating the reservation as a kind of "enterprise zone" free of duties imposed by the state.

Most of the dissent was devoted to demonstrating that allowing the state to tax reservation cigarette sales would defeat federal policies. Attracting purchasers to typically remote reservations required charging substantially lower prices than off-reservation businesses. Tribal dealers would lose substantial revenues if reservation smokeshop sales were taxed by both the state and the tribes. To eliminate the competitive disadvantage and allow reservation merchants to charge no more than offreservation sellers, the tribes would have to forgo exercising their taxing power.

133. See Colville, 447 U.S. at 164-74 (Brennan, J., dissenting); First Draft Colville Opinion, supra note 127, at 14-22. Subsumed within the "cigarette tax issue" were the related decisions that Indians who are not members of the reservation tribe should be treated as non-Indians, that shipments of untaxed cigarettes can be seized by the state on their way to the reservations, and that the state can require Indian merchants to keep records of exempt sales to lndians. Id.

134. Colville, 447 U.S. at 155. But see John Fredericks 11I, State Regulation in Indian Country: The Supreme Court's Marketing Exemptions Concept, a Judicial Sword Through the Heart of Tribal Self-Determination, 50 MoNT. L. Rev. 49, 61-73 (1989) (criticizing the Court's disapproval of tribal "marketing" of tax exemptions).

135. Colville, 447 U.S. at 167 (Brennan, J., dissenting). 
Stewart's concurrence also acknowledged the economic effects on tribes. He would have held that, insofar as the tribal tax functioned the same as the state tax, the state must credit the amount of tribal taxes paid against its own tax. ${ }^{136}$ Under this scenario, the tribes could tax up to the amount of the state's levy without increasing the cost to the consumer. Of course, the state tax would then become the minimum amount of tax paid, whether the revenues went to the tribes or the state. The majority brushed aside Stewart's scheme by concluding that, because the tribes would effectively lose their ability to lower their tax below the state tax in order to draw consumers, they would not be disadvantaged by the absence of a credit. ${ }^{137}$ That logic, however, ignores the fact that tribes could still offer cheaper cigarettes, despite having to apply the full tax, by lowering their wholesale (or retail) markup and hence overall prices charged. ${ }^{138}$

Justice Rehnquist published a separate opinion offering a variation on the majority's preemption analysis. ${ }^{139} \mathrm{He}$ agreed with the majority's outcome but argued that statutes, cases, and historical perceptions must establish a "tradition" of tribal immunity, with respect to the particular subject matter, in order for the Court to find preemption. Here, he argued, the absence of any such tradition was amply demonstrated by the 1898 case of Thomas v. Gay. ${ }^{140}$ That decision allowed state taxation of non-Indian owned cattle on leased tribal land when Indians would not be affected. Rehnquist generalized that "the traditional cases clearly did not find that Indian sovereigu immunity was contravened by subjecting tribes to the burdens inherent in state taxation of the reservation

136. Id. at 175-76 (Stewart, J., concurring). Stewart's theory would allow the state to tax purchases by non-members within the Yakima Reservation because the tribal ordinance "functioned" by taxing only the retailer, while state law imposed the tax on the purchaser. Stewart would invalidate the state tax at the other three reservations, where both the tribal and state taxes fell on the purchaser. See id.

137. Id. at 157-58. The Court recognized that non-members living on the reservation might buy their cigarettes off the reservation in the event of double (state and tribal) taxation. But it held that the tribes had failed to prove a tax credit would prevent such a result.

138. Tribes acting as both wholesalers and taxing entities can adjust total revenues-taxes and profits-to keep the overall price below that charged by off-reservation businesses and thus attract off-reservation purchasers. Moreover, tribes, taxing sales at a rate higher than they otherwise would in order to take full advantage of a credit, could still keep prices down by subsidizing individual sellers (e.g., by leasing land or buildings for stores at below-market rates). Even if profit margins are low, a high volume of sales would guarantee the tribe substantial tax revenue.

139. Colville, 447 U.S. at 176-87 (Rehnquist, J., concurring in part and dissenting in part). The portion of Rehnquist's opinion that constitutes a dissent does not discuss preemption. Id. at 188-90.

140. 169 U.S. 264 (1898). See supra notes 58-59 and accompanying text. Rehnquist conceded that Thomas had not always been followed: several Supreme Court cases relying on the "instrumentality doctrine" had ruled to the contrary, forestalling full implementation of Thomas. Rehnquist nevertheless insisted that Thomas defined the applicable tradition because the instrumentality doctrine was eventually discredited in a non-Indian case. Colville, 447 U.S. at 183 n.8. 
activities of non-Indians." 141 This was dispositive because it indicated that "no express immunity has been granted by Congress."142 $\mathrm{He}$ pressed his point with a vigor that seems inappropriate for a concurring opinion until one discovers that it was originally written as a dissent from Justice Brennan's proposed majority opinion. ${ }^{143}$

As Rehnquist apparently realized, the majority simply did what it thought was fair and sensible. The Court's opinion deplored the practical consequences of allowing reservation businesses to sell goods to non-Indians tax free: "the Tribes could impose a nominal tax and open chains of discount stores at reservation borders, selling goods of all descriptions at deep discounts and drawing custom from surrounding areas." 144 Neither the loss of business opportunities that are fostered by federal laws and policies nor the consequences for tribal governments dependent on the revenues moved the Court. It declared that "[w]hile the Tribes do have an interest in raising revenues for essential governmental programs, that interest is strongest when the revenues are derived from value generated on the reservation by activities involving the Tribes and when the taxpayer is the recipient of tribal services."145 The majority did not confront the preemptive force of federal law promoting tribal economic development, and it did not deal directly with the argument that displacement of the tribes' ability to tax retail sales interfered with tribal self-government. By focusing on whether the tax was on "value generated on the reservation," the Court implied that other activities might still be exempt. That is, if the tribes had grown the tobacco or repackaged the cigarettes on the reservation, perhaps the Court would have found that Indian sovereignty was implicated.

While the Court was considering Colville, two other cases involving state taxation of non-Indians on reservations came before it. In White Mountain Apache Tribe v. Bracker, the Court barred Arizona from imposing its fuel and motor carrier license tax on a non-Indian logging company operating on the reservation. ${ }^{146}$ Central Machinery Co. v. Arizona State Tax Commission held that a non-Indian farm machinery dealer could not be taxed on gross receipts attributable to sales of

141. Colville, 447 U.S. at 182 .

142. Id. at 185.

143. His novel approach was accepted by a majority of the Court in a case decided three years later, but not since. In Rice v. Rehner, 463 U.S. 713, 734-35 (1983), the Court held that, although a federally licensed trader on an Indian reservation is subject to tribal regulation of liquor sales under a specific federal law, the trader also must comply with state liquor licensing and regulatory laws. Justice $\mathrm{O}^{\prime}$ Connor, joined by six members of the Court, held that "tradition simply has not recognized a sovereign immunity or inherent authority in favor of liquor regulation by Indians." Id. at 722.

144. Colville, 447 U.S. at 155.

145. Id. at $156-57$.

146. 448 U.S. $136,137-38$ (1980). 
tractors to a tribal enterprise. ${ }^{147}$ For both cases, Justice Marshall wrote straightforward majority opinions finding that state taxes had been preempted. In White Mountain, the comprehensive federal scheme for regulating timber harvesting and sales left no room for a state tax. In Central Machinery, the tax was preempted by a federal statute under which the transaction might have been regulated, although it was not in fact regulated.

Marshall's opinion in White Mountain is the Court's clearest and most forceful articulation of the McClanahan rule. Marshall described federal preemption and the doctrine of tribal sovereignty as "two independent but related barriers to the assertion of state regulatory authority."148 He emphasized that, in Indian preemption analysis,

[t]he unique historical origins of tribal sovereignty make it generally unhelpful to apply to federal enactments regulating Indian tribes those standards of pre-emption that have emerged in other areas of the law. Tribal reservations are not States, and the differences in the form and nature of their sovereignty make it treacherous to import to one notions of pre-emption that are properly applied to the other. ${ }^{149}$

This is a direct response ${ }^{150}$ to Rehnquist's proposed presumption against tribal sovereiguty in the absence of some active "tradition" of specific tribal jurisdiction, expounded in his Colville concurrence. ${ }^{151}$ Marshall used the opportunity to correct misinterpretations of McClanahan by Rehnquist and the lower courts. ${ }^{152}$ He explained in White Mountain that

147. 448 U.S. $160,161-63$ (1980).

148. White Mountain, 448 U.S. at 142.

149. Id. at 143. Some textbooks had analyzed the Court's emerging preemption doctrine in the same manner. See GETCHES ET AL., supra note 122, at 298-99.

150. Draft opinions in Colville had begun circulating among the Justices a few days before oral argument in White Mountain. Rehnquist's draft was dated January 11, 1980. See First Draft Dissent of Justice William H. Rehnquist, Washington v. Confederated Tribes of Colville Indian Reservation, No. 78-630, at 1 (Jan. 11, 1980), in Brennan Papers, supra note 127. White Mountain and Central Machinery were argued on January 14, 1980.

151. Commentators have feared the misuse of presumptions under the banner of "preemption," see Deborah A. Geier, Essay: Power and Presumptions; Rules and Rhetoric; Institutions and Indian Law, 1994 B.Y.U. L. REv. 451, 453, and use of the preemption analysis as an assimilationist device, see Allen C. Turner, Evolution, Assimilation, and State Control of Gambling in Indian Country: Is Cabazon v. Califomia an Assimilationist Wolf in Preemption Clothing?, 24 IDAHo L. Rev. 317, 337-38 (1987-88).

152. A few courts had been applying preemption principles from other areas of law, the approach eschewed in White Mountain. See Fort Mojave Tribe v. County of San Bernardino, 543 F.2d 1253, 1257 (9th Cir. 1976) ("[S]tate legislation primarily directed at non-Indian lessees of Indian land [is not] automatically preempted by the federal government in the absence of specific authorization."); Crow Tribe of Indians v. Montana, 469 F. Supp. 154, 161 (D. Mont. 1979) (“Absent a specific congressional mandate to the contrary, Montana has the power ... to tax a non-Indian enterprise within its boundaries, even if the situs of the enterprise is within the exterior boundaries of an Indian reservation."), rev'd on other grounds, 650 F.2d 1104 (9th Cir. 1981); California v. Quechan Tribe of Indians, 424 F. Supp. 969, 975 (S.D. Cal. 1977) ("[S]tate regulation ... primarily 
Indian law preemption analysis reads the language of relevant treaties and statutes "in terms of both the broad policies that underlie them and the notions of sovereignty that have developed from historical traditions of tribal independence."153 This approach searches well beyond the words of federal laws, finding preemptive force in the tradition of retained tribal sovereignty.

The Court decided White Mountain and Central Machinery at the very end of the 1980 term and just two weeks after Colville. The different results left lawyers and scholars puzzled as to the applicable rules. Only three Justices had voted in the majority in all three cases! The boundaries of tribal tax immunity became fuzzy, lying somewhere between Colville and the other two cases. Still, it was not unreasonable at the time to see White Mountain-Central Machinery as stating the general rule and Colville, which pieced together a majority from four opinions based on separate rationales, as an exception.

Today, however, Colville is cited more broadly, beyond the facts and circumstances involved in the case. Its ambiguous, less-anchored approach is better suited to legitimating the Justices' subjective judgments than the cleaner preemption test of White Mountain and Central Machinery. Moreover, even White Mountain is currently misinterpreted. An oblique reference to "interests" has been taken as an invitation for courts to balance interests subjectively and search for a result that ought to obtain, without guidance from the historical tradition of tribal sovereignty. ${ }^{154}$

\section{Montana v. United States}

In Montana $v$. United States, ${ }^{155}$ the Supreme Court held that the Crow Indian Tribe lacked authority to regulate non-members hunting and fishing on non-Indian-owned land on its reservation. ${ }^{156}$ During the 1970s, tribes explored new ways to improve dismal reservation economies. Some had begun charging fees to non-Indians for the privilege of hunting and fishing on the reservation, and offering guiding services. Sportsmen wanted richer wildlife and a new, unfamiliar experience; many sought more liberal hunting seasons and limits than were available

directed toward non-Indians... is not preempted... by federal or tribal law, absent specific congressional legislation not here present."), vacated on other grounds, 595 F.2d 1153 (9th Cir. 1979).

153. White Mountain, 448 U.S. at 144-45. In this connection he mentioned that a "particularized inquiry" into the nature of various "interests" would be part of the preemption analysis. Id. at 145; see infra text accompanying notes 260-262.

154. See infra notes 265-275 for a discussion of the Court's subjective balancing in Department of Taxation \& Fin. v. Milhelm Attea \& Bros., 114 S. Ct. 2028 (1994), and Oklahoma Tax Comm'n v. Citizen Band of Potawatomi Tribe, 498 U.S. 505 (1991).

155. 450 U.S. 544 (1981).

156. Id. at $566-67$. 
under state law. Like reservation commercial activities, ${ }^{157}$ hunting and fishing in Indian country had been declared free of state control in modern-era Indian law cases. ${ }^{158}$ Tribes took advantage of their status as jurisdictional enclaves by offering lower prices and relaxed regulationinducements familiar in underdeveloped nations seeking to lure business.

The Crow Tribe of Montana and the Mescalero Apache Tribe of New Mexico both enacted wildlife management laws and began regulating non-Indian sportsmen. The Crow Tribe was concerned about impacts of non-Indian recreationists on reservation resources and acted to halt their taking of fish and game. ${ }^{159}$ Montana, however, persisted in licensing non-Indians to hunt and fish on the Crow Reservation, leading to a confrontation between the two governments. The Mescalero Apache Tribe was pursuing a detailed wildlife management plan as a part of its economic development efforts. It had built a resort and was working with federal agencies to stock reservation streams and increase elk herds. The State of New Mexico continued to require non-Indians to have state licenses and to follow limits and seasons different from tribal regulations.

The district court in Montana extended Oliphant's bar on tribal criminal jurisdiction over non-Indians to the sphere of tribal civil regulatory jurisdiction. The Ninth Circuit Court of Appeals reversed. ${ }^{160}$ It addressed a different ground, finding that the tribe owned the bed and banks of the Big Horn River and held that, as a landowner entitled to exclude people from its property, it could also regulate those who came to fish or hunt. The court then answered the question of tribal jurisdiction over non-Indian-owned lands adjacent to the tribal river bed with a Solomonic gesture. It declared that the tribe had authority to regulate, but not to prohibit, non-Indian fishing and hunting.

After the Tenth Circuit in Mescalero also held for the tribe, ${ }^{161}$ the two states sought Supreme Court review. The Court granted certiorari in the Montana case and, pending its resolution, held the Mescalero petition.

157. See Warren Trading Post Co. v. Arizona State Tax Comm'n, 380 U.S. 685, 691-92 (1965); Williams v. Lee, 358 U.S. 217, $222-23$ (1959).

158. See, e.g., Menominee Tribe of Indians v. United States, 391 U.S. 404, $412-13$ (1968).

159. See United States v. Montana, 604 F.2d 1162, 1168 n.11A (9tb Cir. 1979), rev'd on other grounds, 450 U.S. 544 (1981). To allay these concerns, the Crow Tribal Council passed Resolution 74-05 in 1973, which prohibited hunting and fishing within the reservation by anyone other than members of the Crow Tribe. Id. at $1164 \&$ n. 4 .

160. Id. at 1164.

161. Mescalero Apache Tribe v. New Mexico, 630 F.2d 724, 734-35 (10th Cir. 1980), vacated, 450 U.S. 1036 (1981). 
The Supreme Court reversed, deciding the Crows' case in favor of Montana. ${ }^{162}$ It declared that tribes lose a component of their aboriginal sovereignty when they convey land to non-Indians. In dicta, the Court created two exceptions to this rule: (1) a tribe may retain jurisdiction over non-Indians engaged in "consensual relationships with the tribe or its members, through commercial dealing, contracts, leases, or other arrangements;"163 and (2) a tribe may retain "inherent power to exercise civil authority over the conduct of non-Indians on fee lands within its reservation when that conduct threatens or has some direct effect on the political integrity, the economic security, or the health or welfare of the tribe." 164 The second exception effectively left the fate of tribal sovereignty up to the subjective evaluations of future courts.

The Montana Court held that neither of these exceptions applied to the Crow Tribe's hunting and fishing regulations. The tribe did not have consensual relations with the non-Indians, and the Court could not see how important tribal interests would be threatened by application of Montana's rules. The Court found that in the past, the tribe had "accommodated itself to the State's 'near exclusive' regulation"165 because it had not tried to forbid non-Indian hunting and fishing on reservation lands at the time the Crow Allotment Act of 1920 was approved. By rejecting the usual presumption of tribal jurisdiction in Indian country, Montana invited courts to weigh evidence of various interests and efforts in every case involving activities on non-Indianowned lands. It thus created the potential for different outcomes for each reservation regulation and tax.

In reaching its decision, the Montana Court announced remarkable departures from established Indian law principles. First, it ruled that title to the river bed passed to the state on statehood. It thus narrowed criteria for defining tribal rights to such property laid down only eleven years earlier. ${ }^{166}$ Then, the Court limited the tribe's authority to regulate non-Indian conduct on the reservation, effectively retreating from the

162. Montana, 450 U.S. at 566-67.

163. Id. at 565 .

164. Id. at 566 .

165. Id.; see also id. at $564-65 \mathrm{n} .13$.

166. The legal question was whether the river bed passed from the United States to the Indians when the government entered into treaties recognizing a reservation with the Big Horn River running through the middle of it. It is an established principle of public land law that, prior to statehood, the United States holds the land underlying navigable rivers in trust for future states. United States v. Holt State Bank, 270 U.S. 49, 55 (1926). Upon statehood title to the river bed passes to the new state. Id. at 59. Not long before Montana arose, the Supreme Court ruled that where the river in question was included in an Indian reservation created by a treaty prior to statehood, the river bed belongs to the tribe. Choctaw Nation v. Oklahoma, 397 U.S. 620, 635-36 (1970). The federal government argued that this special rule for Indian reservations applied to the Crow Reservation. The Montana Court, however, narrowly construed Choctaw as based on a treaty promise that the Choctaw Reservation would not be included within any state. Montana, 450 U.S. at 555 n.5. 
previons year's dictum in Colville that "Indian tribes possess a broad measure of civil jurisdiction over the activities of non-Indians on Indian reservation lands in which the tribes have a significant interest."167 Montana justified its restriction of tribal rights with a citation to Oliphant for the general proposition that "the inherent sovereign powers of an Indian tribe do not extend to the activities of non-Indians or non-members of the tribe."168

Montana's denial of tribal authority over non-members was based on two grounds. First, the Court held that the Fort Laramie Treaty, which established the Crow Reservation for the "absolute and undisturbed use and occupation" of the Indians, was implicitly abrogated by the Crow Allotment Act, ${ }^{169}$ which alienated much of the Crow land to non-Indians. The Court's reliance on the Act was notable, as that legislation did not specifically limit or remove the tribe's authority over hunting and fishing on allotted lands. Furthermore, Congress has generally affirmed that allotted land remains Indian country and is therefore subject to tribal and federal law to the exclusion of state law. ${ }^{170}$ As discussed below, ${ }^{171}$ the Allotment Acts came about during a short-lived period of assimilationist fervor in Congress, a policy that was repudiated in subsequent legislation. In Montana, though, the Court gave the policy a new vitality. ${ }^{172}$

167. Colville, 447 U.S. at 152-53. This case had not yet been decided at the time of the Ninth Circuit Montana decision.

168. Montana, 450 U.S. at 565.

169. 41 Stat. 751 (1920). See Montana, 450 U.S. at 558-59.

170. Crimes and Criminal Procedure Act of 1948, 18 U.S.C. $\& 1151$ (1994). The Supreme Court states in several cases that Congress has accepted the Court's characterization of all land within reservation boundaries as Indian country, thereby decoupling land ownership from the issue of jurisdiction. See, e.g., Solem v. Bartlett, 465 U.S. 463, 468 (1984).

The Court's departure from this principle may have been induced by the way Montana was presented. The United States took up the tribe's cause and made the primary issue ownership of the bed of the Big Hom River, which was the part of the reservation most attractive to non-Indians for sport fishing and duck hunting. The government tied the tribe's power to regulate hunting and fishing to the claim that the bed and banks belonged to the tribe, apparently believing that the ownership argument was strong and would bolster the jurisdiction argument. Once the ownership issue was decided against the Crows, the Court saw the case as involving a corridor of state land flanked by lands owned by non-Indians who had bought allotments. The government's "fallback" position asserting sovereignty principles may have seemed less convincing after the United States had staked the case principally on tribal land ownership.

171. For a discussion of Brendale v. Confederated Tribes \& Bands of Yakima Indian Nation, 492 U.S. 408 (1989), and the Court's understanding of the allotment policy, see infra Part 11.A.4. For references to the allotment policy in several decisions where tribes lost sovereignty through the reduction of reservation boundaries, sec Hagen v. Utah, 510 U.S. 399 passim (1994); Montana, 450 U.S. at $559 \mathrm{n} .9$; Mescalero, 630 F.2d at 734-35; see also infra text accompanying notes 223-251. But see Bryan v. Itasca County, 426 U.S. 373, 388-89 n.14 (1976) (noting that federal policy appears to reject assimilationism in construing the prerogatives of tribal sovereignty).

172. The Court recognized that the Indian Reorganization Act of 1934, 25 U.S.C. $\$ \S 461-479$, explicitly ended the allotment policy, but it continued to look to the purposes of the Allotment Act to determine the effect of alienation of reservation lands to non-lndians. Montana, 450 U.S. at 559 n.9. 
Second, the Court limited the tribe's inherent sovereignty because "regulation of hunting and fishing by non-members of a tribe on lands no longer owned by the tribe bears no clear relationship to tribal selfgovernment or internal relations."173 This was an extension of Rehnquist's idea in Oliphant that Indian powers could be divested if they were inconsistent with the sovereign interests of the United States. ${ }^{174}$ Oliphant had opened the way for subjective, case-by-case determinations of whether a tribe retained its inherent sovereignty in particular circumstances. The Montana Court followed its example but made no attempt to link the denial of tribal sovereignty to a fundamental inconsistency with federal sovereignty.

Other cases decided at the same time as Montana produced markedly different results. Incredibly, most of them were based on foundation principles. Mescalero Apache Tribe v. New Mexico also involved a tribe's regnlation of hunting and fishing on its New Mexico reservation. The case was vacated and remanded for reconsideration in light of Montana, ${ }^{175}$ and the Tenth Circuit adhered to its earlier decision upholding tribal sovereignty. ${ }^{176}$ The Supreme Court affirmed because, unlike Montana, the case did not involve non-Indian lands on the reservation. ${ }^{177}$ Justice Marshall wrote for the Court that Montana assumed tribes can restrict hunting and fishing by non-members on tribal land, a matter that was conceded by New Mexico. ${ }^{178}$

The State of New Mexico had argued that it had concurrent jurisdiction over the non-members and that its seasons, bag limits, and gear restrictions should prevail whenever they were more restrictive than the tribe's. Justice Marshall recognized that concurrent state authority was preempted by federal law and would interfere with tribal sovereignty. Preemption came from "broad considerations" of policy favoring tribal self-government, self-sufficiency, and economic development. ${ }^{179}$ These goals, embodied in a host of federal statutes, would be defeated by allowing the state to regnlate. Marshall explained that the state's parallel but inconsistent wildlife management program could not peace-

173. Montana, 450 U.S. at 564.

174. The Oliphant Court found that tribal jurisdiction over non-Indians was a threat to the national interest in protecting the civil liberties of criminal defendants. I have argued above that Oliphant's lowering of the threshold at which tribal powers are extinguished was a departure from established principles of Indian law. The earliest tribal sovereignty cases taught that only those powers that would be fundamentally inimical to the sovereignty of the United States (such as authority to convey land to non-Indians or to maintain foreign relations) were lost by the Indians when they were brought under the United States flag. See supra notes 99-102.

175. 450 U.S. 1036,1036 (1981).

176. See Mescalero Apache Tribe v. New Mexico, 677 F.2d 55, 57 (10th Cir. 1982).

177. See New Mexico v. Mesealero Apache Tribe, 462 U.S. 324, 330-31 (1983).

178. Id. at 331 .

179. Id. at 334-36. 
fully coexist with the tribal program because the tribal plan's success depends on achieving "the optimal level of hunting and fishing ... not simply a maximum level that should not be exceeded."180

Mescalero concluded that "the Tribe's authority to control hunting and fishing preempts state jurisdiction."181 State law, then, was preempted by tribal legislation supported by federal policy. This kind of "tribal preemption" is what the Court denied in Colville when it held that Montana could apply its cigarette tax to reservation sales despite the existence of a tribal tax, a situation that would surely undermine the tribe's cigarette business or emasculate its taxing program. Perhaps the Justices viewed Mescalero differently because the fish and game (though mostly stocked) were more indigenous to the reservation than the cigarettes in Colville. ${ }^{182}$

Justice Marshall was able to command a unanimous Court in Mescalero despite the fact that individual Justices were on record as disagreeing with his analysis in previous preemption cases. Justice Stewart, the author of Montana, was uncomfortable with Marshall's presumption favoring tribal jurisdiction where no federal law dictated otherwise. But he found that Montana's exception for "tribal authority over matters demonstrably affecting the economic welfare of the Tribe or the proper exercise of its self-government" applied because the Mescalero Apaches owned the land and had a "much greater investment and interest in wildlife" than the Crows had in Montana. ${ }^{183}$

The next term, a majority of the Court joined Marshall in a decision that used the White Mountain-Central Machinery preemption approach to exempt a non-Indian contractor building a school on a reservation from state gross receipts taxes. ${ }^{184}$ And in another case, Merrion v. Jicarilla Apache Tribe ${ }^{185}$ Marshall commanded a majority that allowed tribes to impose severance taxes on non-Indian mineral producers on reservation lands. All of these decisions applied foundation principles. After Montana, however, such cases became increasingly rare. More and more, the Court became attracted to the subjectivist approach in Indian law, culminating in a 1989 decision redefining tribal reservation zoning rights.

180. Id. at $338-40$.

181. Id. at 338 .

182. See supra notes $144-145$ and accompanying text.

183. Memorandum from Justice Potter Stewart to the Conference (Apr. 1, 1981) (Montana v. United States, No. 79-1128; New Mexico v. Mescalero Apache Tribe, No. 80-778), in Marshall Papers, supra note 4.

184. Ramah Navajo Sch. Bd. v. Bureau of Revenue, 458 U.S. 832, 834 (1982). Justice O'Connor replaced Justice Stewart in the October 1981 Term and joined the majority.

185. 455 U.S. 130, 136 (1982), discussed infra text accompanying notes 197-202. 
4. Brendale v. Confederated Tribes \& Bands of the Yakima Indian Nation

Oliphant, Colville, and Montana announced a welter of new "rules" for reservation jurisdiction cases involving non-Indians. Others have commented upon the disarray that the ad hoc nature of these decisions created. ${ }^{186}$ The confusion was exacerbated by Brendale $v$. Confederated Tribes \& Bands of the Yakima Indian Nation, ${ }^{187}$ in which the Court reached new extremes of judicial subjectivity and at the same time produced highly impractical results. The question in Brendale was whether the county or the tribe had zoning authority over non-Indianowned land on the Yakima Indian reservation. The outcome was that about two-thirds of the reservation land, whether owned by Indians or non-Indians, would be zoned exclusively by the tribe. Zoning authority over the other third was split between the tribe and the county, depending on the race of the owner of the specific parcel. The decision was not tied to any particular doctrine or rationale, but was supposed to reflect the realities of current demographics and land ownership. A combination of divergent plurality opinions produced this helter-skelter distribution of zoning authority-a result that only two Justices favored.

Ironically, the Court had earlier emphasized the importance of avoiding "an impractical pattern of checkerboard jurisdiction" that "depends upon the ownership of particular parcels of land, [so that officials] operating in the area will find it necessary to search tract books." 188 This conceru was ignored in Montana, which held that tribal authority over reservation lands owned by non-Indians would vary according to political, economic, and social factors. Brendale added another level of complexity by giving different authorities jurisdiction over different parts of the same reservation, if a high percentage of land was currently owned by non-Indians.

The Brendale Court produced three separate opinions, none of which commanded a majority of the Justices. Rehnquist, Scalia, and Kennedy joined White's opinion, which would have denied the tribe zoning authority over all non-Indian-owned land. Marshall and Brennan signed an opinion by Blackmun insisting on tribal power to zone the whole reservation. Only Stevens and O'Connor explicitly favored creating a jurisdictional checkerboard, but the Court's frag-

186. See Allison M. Dussias, Geographically-Based and Membership-Based Views of Indian Tribal Sovereignty: The Supreme Court's Changing Vision, 55 U. PITT. L. Rev. I, 41 (1993) ("Oliphant ... left confusion among federal, state and tribal officials."); Frank R. Pommersheim, The Crucible of Sovereignty: Analyzing Issues of Tribal Jurisdiction, 31 ARIz. L. Rev. 329, 334 (1989) ("The Supreme Court's recent decisions render the scope of tribal court jurisdiction ever more uncertain.").

187. 492 U.S. 408 (1989).

188. Seymour v. Superintendent of Wash. State Penitentiary, 368 U.S. 35I, 358 (1962). 
mented pluralities allowed them to get their way. With concurrence by Blackmun, Marshall, and Brennan, they held that the tribe could zone non-Indian land on one part of the reservation. Meanwhile, White, Rehnquist, Scalia, and Kennedy joined them in holding that the county, not the tribe, could zone non-Indian land on the rest of the reservation.

Brendale offers various interpretations of the Montana decision without reaching agreement among the Justices as to which is correct. White's version of Montana would preclude any tribal zoning of nonIndian-owned lands on the reservation. He found that the exception to Montana's presumption against tribal jurisdiction over non-Indian land did not apply because no activity allowed by the state on the land would threaten "the political integrity, the economic security, or the health or welfare of the tribe."189 For state jurisdiction to be pre-empted, White would require not only that the nature of the regulated activity affect the tribe, but that a particular activity permitted by the state "imperil" tribal interests. In addition, a federal court could make an inquiry into the matter only after state authorities had fully exercised jurisdiction. In Brendale, therefore, White reduced protection for tribal government under the Montana "exception" to the right to bring a federal lawsuit challenging a county decision only after the tribe has unsuccessfully appealed to the Board of Commissioners. The federal court would then ask if identifiable activities allowed by the county on a particular parcel imperiled tribal autonomy or welfare.

Blackmun's dissent insisted that White misread Montana when he presumed that tribes have no civil jurisdiction over non-Indians unless Congress consents. Even the Montana Court had recognized that "tribes may regulate the on-reservation conduct of non-Indians whenever a significant tribal interest is threatened or directly affected." 190 Here, the tribe's comprehensive reservation land use and zoning scheme was at stake. The tribe thus faced "the loss of the general and longer term advantages of comprehensive land management."191 White ignored these issues by requiring that the "impact [on the tribe] be de-

189. Brendale, 492 U.S. at 428 (quoting Montana, 450 U.S. at 566 , quoted more fully supra text accompanying note 164).

190. Id. at 457 (Blackmun, J., dissenting). Blackmun was moved to construe Montana narrowly by the fact that in eight years the case had not been followed and had hardly even been cited. He noted that Montana's rule of tribal sovereignty had been invoked only in a dissent in Merrion v. Jicarilla Apache Tribe, 455 U.S. 130, 171 (1982) (Stevens, J., dissenting), and a dissent to a denial of certiorari in City of Polson v. Confederated Salish \& Kootenai Tribes, 459 U.S. 977 (1982) (Rehnquist, J., dissenting). Brendale, 492 U.S. at 456 n.6 (Blackmun, J., dissenting). But see lowa Mut. Ins. Co. v. LaPlante, 480 U.S. 9, 18 (1987) (citing Montana); National Farmers Union Ins. Cos. v. Crow Tribe of lndians, 471 U.S. 845, 851 n.12 (1985) (same); New Mexico v. Mescalero Apache Tribe, 462 U.S. 324, 330-31 (1983) (same); cf. South Dakota v. Bourland, 508 U.S. 679, 688 (1993) (citing Montana after Brendale).

191. Brendale, 492 U.S. at 460 (Blackmun, J., dissenting). 
monstrably serious" and by assuming most problems will be avoided if local zoning officials have an opportunity to give "due regard" to tribal interests. ${ }^{192}$ White's interpretation of Montana thus denigrated the important tribal interest in making the rules that govern their own reservations.

Stevens, like White, cited the Allotment Act to justify his result. Conceding that " $[\mathrm{z}]$ oning is the process whereby a community defines its essential character," ${ }^{193}$ he nevertheless concluded that allotment terminated tribal zoning authority over non-member lands in parts of the reservation, at least where "large portions of the reservation were sold in fee." 194 White saw the Act as divesting the tribe of that authority throughout the entire reservation, while Blackmun's dissent followed traditional principles by assuming tribal power endures until clearly abrogated by Congress.

Stevens' formulation, which determined the outcome in Brendale, gave no clear indication of when non-member ownership of reservation land would become extensive enough to abrogate the tribe's inherent authority. Stevens appears to have been striving for a result that he considered fair and reasonable under the facts. His opinion does not pretend to engage in a principled exercise in statutory construction and does not guide later courts beyond the contemporary situation of the Yakima Reservation. In fact, Stevens presented "a patently unworkable legal rule." "195 At least at Yakima, unlike on most reservations, there was a working definition of "opened" and "closed" portions of the reservation that was employed by the parties during the litigation of the cases. While the distinction lacked any official force, it could be used to delineate between those areas where tribal sovereignty had been abrogated by the Allotment Act and those where the tribe retained jurisdiction.

Brendale left the doctrine mired in profound confusion. Each of the three opinions is dominated by bickering with the other two; 196 they read more like briefs than judicial decisions. Neither White nor Stevens, as authors of the respective plurality opinions, took responsibility for synthesizing an understandable rule or principle. Perhaps the Chief Justice should have attempted to force a reconciliation to avoid the em-

192. Id. at 431 .

193. Id. at 433 .

194. Id. at 437 .

195. Id. at 448 (Blackmun, J., dissenting). Justice White also warned that "the practical consequences of Justice Stevens' approach will be severe." Id. at $425 \mathrm{n} .8$. White, however, was principally concerned that it would "allow[] Indian tribes to obtain the power to zone by defining areas on their reservations that contain only a 'small percentage' of fee lands." Id.

196. Of the 101 paragraphs in the three opinions, 25 quibble with other members of the Court. Of a total of $\mathbf{2 7}$ footnotes, seven are used to debate other Justices' positions. 
barrassment of a public quarrel that has left those who must interpret the decision in a quandary.

Brendale's value as precedent will be limited except in a case with nearly identical subject matter and facts-zoning on a reservation with similar land tenure and demographics. Otherwise, it gives litigators and lower courts wide latitude to generate their own theories about tribal authority. Nevertheless, Brendale remains a stunning example of the willingness of most members of the present Supreme Court to act on their subjective views of the merits. The three dissenters in that case, who urged the use of foundation principles, have all retired.

\section{B. The Other Line: Vestiges of the Foundations}

Even as subjectivism became a theme in the Supreme Court's Indian law jurisprudence, many opinions continued to pronounce foundation principles. Arguably, these principles were simply recited in cases where they supported a result that coincided with the majority's perception of the desirable "state of affairs." Nevertheless, several important decisions from the 1980s employed the traditional approach and could provide a principled basis for returning Indian law to foundation precepts. Indeed, because these decisions state their rationales more clearly than the numerous subjectivist opinions, they could be influential if a future Court tries to bring doctrinal coherence to tribal sovereignty law.

Between Montana (1981) and Brendale (1989), several major decisions provided expansive views of tribal sovereignty. Two cases involved regulatory jurisdiction. Merrion v. Jicarilla Apache Tribe ${ }^{197}$ affirmed tribal power to tax reservation mineral production by nonIndian companies. And in New Mexico v. Mescalero Apache Tribe, ${ }^{198}$ the Court found that tribal wildlife laws effectively preempted state law. The Court also issued two opinions requiring federal judicial deference to tribal sovereignty. In both cases, the Court held that challenges to tribal jurisdiction over civil suits arising on reservations must first be brought in tribal court. ${ }^{199}$ The period was also marked by an historic ruling allowing the Oneida Indian Nation to pursue claims that title to lands in the State of New York had been unlawfully obtained from them

197. 455 U.S. 130 (1982). See also Kerr-McGee Corp. v. Navajo Tribe of Indians, 471 U.S. 195 (1985) (taxing power of tribes upheld in Merrion does not depend on Secretary of Interior's approval of tribal ordinance).

198. 462 U.S. 324 (1983). See supra notes $176-183$ and accompanying text.

199. See Iowa Mut. Ins. Co. v. LaPlante, 480 U.S. 9 (1987) (federal diversity jurisdiction only after remedies exhausted in tribal court); National Farmers Union Ins. Cos. v. Crow Tribe of Indians, 471 U.S. 845 (1985) (tribal jurisdiction over subject matter raises a federal question but must be decided in the first instance by the tribal court). 
two centuries before. ${ }^{200}$ All five of these decisions cited to foundation principles.

The five decisions, however, remain somewhat precarious and mitigated by their circumstances. Merrion is illustrative. An apparently strong majority vote (6-3) masked underlying confusion and indecision among the Justices. An opinion by Justice Stevens reaching the opposite result was almost issued, after which several equivocal Justices joined what was originally Justice Marshall's draft dissent. ${ }^{201}$ Later the Court, per Justice Stevens, limited the great economic potential of Merrion by

200. County of Oneida v. Oneida Indian Nation, 470 U.S. 226 (1985).

201. Justice Stevens circulated a draft opinion for the Court that was identical in substance to his published dissent. First Draft Opinion of Justice John Paul Stevens, Merrion v. Jicarilla Apache Tribe, No. 80-11 (June 1, 1981) (Amoco Prod. Co. v. Jicarilla Apache Tribe, No. 80-15; Merrion v. Jicarilla Apache Tribe, No. 80-11) [hereinafter First Draft Merrion Opinion], in Marshall Papers, supra note 4. Stevens' erstwhile majority opinion rejected the Indians' power to tax because, he argued, it was based on tribal power to exclude non-members from the reservation, something that the tribe had given up when it entered into the lease with the mining company. This rationale is different from the one the Justices discussed when they voted in conference. See Memorandum from Justice John Paul Stevens to the Conference (June 1, 1981) (Amoco Prod. Co. v. Jicarilla Apache Tribe, No. 80-15; Merrion v. Jicarilla Apache Tribe, No. 80-11), in Marshall Papers, supra note 4. Chief Justice Burger and Justice Rehnquist said they would join. Because Justice Stewart recused himself, it would take five votes to overrule the court of appeals' decision upholding the tax, but only four to affirm. See Hannis Taylor, Jurisdiction and Procedure of the Supreme Court of the United States 715 (1905).

Justice Marshall circulated a dissent similar to what became the majority opinion. First Draft Dissent of Justice Thurgood Marshall, Merrion v. Jicarilla Apache Tribe, No. 80-11 (June 25, 1981) (Amoco Prod. Co. v. Jicarilla Apache Tribe, No. 80-15; Merrion v. Jicarilla Apache Tribe, No. 8011) [hereinafter First Draft Merrion Dissent], in Marshall Papers, supra note 4. Justice Brennan said he would join. Although Justice White viewed the tribe's power to exclude non-lndians as the basis for its taxing power, he accepted Marshall's conclusion. Justices Blackmun and Powell wanted the tribal tax reviewed for compliance with interstate commerce clause restraints and voted to vacate and remand. This left the case one vote short of the four nceded to affirm. Then, in the waning days of the term, Blackmun submitted a brief dissent accepting Marshall's argument that because Congress had created a mechanism for federal administrative approval of the tribal taxing ordinance, the Commerce Clause was not an obstacle and the tax was valid. With Blackmun and Powell, there would be five votes to affirm. However, there was not enough time left in the term to rework the opinions.

When the new term began, the case was reargued before a new Court, Justice Stewart having been replaced by Justice $O^{\prime}$ Connor. The majority opinion was assigned to Justice Marshall. The day the draft was circulated, Brennan joined. After making changes to accommodate them, Marshall secured the votes of Blackmun and Powell. See Memorandum from Justice Harry A. Blackmun to Justice Thurgood Marshall (Jan. 11, 1982) (Amoco Prod. Co. v. Jicarilla Apache Tribe, No. 80-15; Merrion v. Jicarilla Apache Tribe, No. 80-11) (demanding specific changes as a condition for joining Marshall's opinion), in Marshall Papers, supra note 4; Memorandum from Justice Lewis F. Powell, Jr. to Justice Thurgood Marshall (Jan. 11, 1982) (Amoco Prod. Co. v. Jicarilla Apache Tribe, No. 80-15; Merrion v. Jicarilla Apache Tribe, No. 80-11) (same), in Marshall Papers, supra note 4. Justice O'Connor also joined Marshall's opinion. After toying with joining the dissent, White joined too. Memorandum from Justice Byron R. White to Justice Thurgood Marshall (Jan. 5, 1982) (Amoco Prod. Co. v. Jicarilla Apache Tribe, No. 80-15; Merrion v. Jicarilla Apache Tribe, No. 80-11), in Marshall Papers, supra note 4. Justice Stevens wrote a dissent joined by Rehnquist and Burger. 
allowing the state, as well as the tribe, to tax reservation mineral production. ${ }^{202}$

It should also be pointed out that there were other decisions from this era whose outcomes favored tribal sovereignty but were not based on foundation principles. The best example is California $v$. Cabazon Band of Mission Indians, ${ }^{203}$ a landmark case allowing a tribal casino to operate on a California reservation despite contrary state and local laws. Justice White's majority opinion (6-3) might have relied on foundation principles, but instead employed a balancing test. ${ }^{204}$ Federal interests, which are considered parallel to tribal interests, were deemed heavy enough to outweigh state interests. Because California permitted some types of gambling, its public policy would not be undermined by tribally sponsored gambling, even if the particular type did not comply with state law. But in dicta Cabazon notes that if gambling offended non-Indian values deeply enough, jurisdiction to control gambling on

202. See Cotton Petroleum Corp. v. New Mexico, 490 U.S. 163 (1989). Oil companies challenged state taxation of oil and gas production on the Jicarilla Apache Reservation. The New Mexico Court of Appeals held against the eompanies, upholding the constitutionality of the state tax. Cotton Petroleum v. State, 745 P.2d 1170 (N.M. Ct. App. 1987). Justice Stevens' opinion recast the question raised as "whether Congress has acted to grant the Tribe such immunity." Cotton, 490 U.S. at 175. He thus turned the Court's Indian preemption analysis on its head by starting with a presumption against the preemption of state law; this is the approach normally reserved for federalstate preemption cases.

Even with a presumption in favor of state taxation, Stevens' opinion had to go through some contortions to uphold New Mexico's tax. Just four years earlier, the Court had barred state taxation of tribal royalties under oil and gas leases issued to non-Indian eompanies. Montana v. Blackfeet Tribe of Indians, 471 U.S. 759 (1985). That case heId that a 1938 Indian mineral leasing law had effectively repealed a 1924 Act allowing the states to tax reservation oil and gas. The tribe's royalties from reservation production of oil and gas were therefore exempt from state taxation. Justice Stevens, who dissented in Blackfeet Tribe, distinguished it in Cotton as involving direct taxes on tribes, which would require clear congressional consent, and then decided that other state taxation of reservation activities should be permitted unless preempted by Congress. Taxes on royalties were found to be more direct than the taxes imposed on lessee oil companies. Cotton, 490 U.S. at 183 n.14. The 1938 Act, repealing the 1927 Act's authorization of state taxation, did not provide any evidence of clear congressional consent to direct state taxation of Indians. Nor, however, did it expressly preclude other, less direct state taxes. Justice Stevens seized on this absence of express preemption of state law as to "indirect" taxes to manuever past the Blackfeet Tribe decision's bar on Montana's oil and gas royalty tax and to allow New Mexico's taxation of oil companies' reservation activities, regardless of the economic impacts on the tribe.

Professor Clinton has argued that Cotton's rejection of a Commerce Clause barrier to the exercise of state jurisdiction in Indian country flies in the face of the framers' understanding of the clause. Robert N. Clinton, The Dormant Indian Commerce Clause, 27 CoNN. L. REv. 1055, 1221-22 (1995).

203. 480 U.S. 202 (1987).

204. It appears from Justice Marshall's notes that only Justice Stevens voted to reverse at conference. After a draft opinion was circulated on Feb. 3, 1987, Justice O'Connor wrote: “Please join me in your dissent. I tentatively voted the other way at Conference, but I am persuaded you are right." Memorandum from Justice Sandra Day O'Connor to Justice John Paul Stevens (Feb. 12, 1987) (California v. Cabazon Band of Mission Indians, No. 85-1708), in Marshall Papers, supra note 4. Justice Scalia also ultimately joined Stevens. 
the reservation would pass to the state. ${ }^{205}$ Cabazon ultimately succumbs to a subjectivist approach, concluding that tribal immunity from state law would be permitted because, on balance, reservation gambling would not be overly offensive to California. ${ }^{206}$ Nevertheless, by allowing Indians to host gambling operations free of state control, the case has done more for some tribal economies than all the federal government's Native American development programs since the nation's founding.

\section{The New Rules of Judicial Subjectivism}

While subjectivism has not totally eclipsed foundation principles, it has required the institution of certain new rules. Three themes mark the subjectivist era. First, the Court has retreated from established canons of construction that were protective of Indian rights. Second, some Justices, recognizing that definitions of tribal sovereignty should be tied to congressional action or policy, have begun looking to nineteenthcentury policies of allotment and assimilation as the benchmark for definiug appropriate limits on Indian autonomy. And third, the Court has assumed the prerogative of balancing various non-Indian interests in order to prune tribal sovereignty to the Court's own notion of what it ought to look like.

\section{Retreat from the Established Canons of Construction}

Special rules for construing laws and treaties affecting Indians have evolved through 150 years of Supreme Court jurisprudence. ${ }^{207}$ The rules counsel that ambiguities will be resolved in favor of Indians ${ }^{208}$ and that tribal sovereignty may only be abrogated with a clear statement of congressional intent. ${ }^{209}$ The canons of construction were first applied in treaty cases, where tribal bargaining power was limited and language

205. Cabazon, 480 U.S. at $216,220-22$.

206. See infra text accompanying notes 252-275. Cabazon delves into the state's public policy ostensibly because California is a Public Law 280 state. In 1953, Congress granted California and certain other states authority to enforce state criminal laws on reservations, but not jurisdiction over civil regulatory matters. See 18 U.S.C. § 1162(a) (1994) (criminal); 28 U.S.C. § 1360(b) (1994) (civil); see also Bryan v. Itasca County, 426 U.S. 373 (1976). The Supreme Court had drawn a distinction between regulations that are regulatory and those that are prohibitory. The latter are considered within Public Law 280's grant of jurisdiction to the states because a prohibitory regulation is analogous to a crime. A similar distinction has been used to determine which state regulations are "crimes" within the Assimilative Crimes Act, 18 U.S.C. $\S 13$ (1994), a general law of the United States made applicable to Indian country under 18 U.S.C. \& 1152 (1994). United States v. Marcyes, 557 F.2d 1361 (9th Cir. 1977) (finding that a state law intended to prohibit, not regulate, fireworks was tantamount to a criminal law).

207. See COHEN (1982), supra note 2, at 221-22.

208. See, e.g., Winters v. United States, 207 U.S. 564, 576 (1908); Worcester v. Georgia, 31 U.S. 515,582 (1832).

209. See COHEN (1982), supra note 2, at 222-25; GETCHES ET AL., supra note 15, at 345-48; see also infra note 240 and accompanying text. 
barriers abounded. ${ }^{210}$ The Court extended the rule to cover statutes, ${ }^{211}$ in recognition of the fiduciary relationship of the United States to the tribes. ${ }^{212}$

The Court has always assumed that Congress may do virtually anything it wants to alter tribal powers and rights, even abrogate Indian treaties unilaterally. ${ }^{213}$ However, because this power is rooted in a trust relationship, Congress is presumed to act in the best interests of the tribes. ${ }^{214}$ A federal law will thus be understood to diminish tribal powers or immunity only if Congress" intent to do so is "clear and plain."215 Hence, the general rule is against the implied abrogation of Indian rights.

While the Court may continue to cite the canons, it is difficult to attribute any significance to them in many recent cases. ${ }^{216}$ When construing legislation opening Indian country to non-Indian occupancy, the Court has generally resisted diminishing reservation boundaries absent clear evidence that Congress intended to divest the tribe not only of parcels of land but the power to govern the area. ${ }^{217}$ The Court now dis-

210. See, e.g., Choctaw Nation v. Oklahoma, 397 U.S. 620, 630-31 (1970) ("The Indian Nations did not seek out the United States and agree upon an exchange of lands in an arm's-length transaction. Rather, treaties were imposed upon them and they had no choice but to consent."); Jones v. Meehan, 175 U.S. 1, 11 (1899):

[T]he negotiations for the treaty are conducted, on the part of the United States, an enlightened and powerful nation, by representatives skilled in diplomacy, masters of a written language, understanding the modes and forms of creating the various technical estates known to their law ... [and] that the Indians, on the other hand, are a weak and dependent people, who have no written language... and whose only knowledge of the terms in which the treaty is framed is that imparted to them by the interpreter employed by the United States....

211. See, e.g., Montana v. Blackfeet Tribe of Indians, 471 U.S. 759, 766 (1985); Bryan v. Itasca County, 426 U.S. 373, 392 (1976); McClanahan v. Ariz. State Tax Comm'n, 411 U.S. 164, 174 (1973); Choate v. Trapp, 224 U.S. 665,675 (1912).

212. See, e.g., County of Oneida v. Oneida Indian Nation, 470 U.S. 226, 247 (1985) (canons "are rooted in the unique trust relationship between the United States and the Indians"); Carpenter v. Shaw, 280 U.S. 363, 367 (1930) ("Doubtful expressions are to be resolved in favor of the weak and defenseless people who are the wards of the nation, dependent upon its protection and good faith.").

213. See Lone Wolf v. Hitchcock, 187 U.S. 553, 565 (1903) ("Plenary authority over the tribal relations of the Indians has been exercised by Congress from the beginning, and the power has always been deemed a political one, not subject to be controlled by the judicial department of the government."); see also supra note 45 and accompanying text.

214. See, e.g., United States v. Dion, 476 U.S. 734, 738 (1986).

215. Id.; see also Menominee Tribe of Indians v. United States, 391 U.S. 404, $412-13$ (1968) (holding that the intention to abrogate or modify a treaty should not be "lightly imputed" to the Congress); United States v. Santa Fe Pac. R.R., 314 U.S. 339, $353-54$ (1941) (requiring clear congressional intent to abrogate Indian title to ancestral lands); $c f$. Williams v. Lee, 358 U.S. 217, 221 (1958) (requiring clear statement of congressional intent to allow state civil or criminal jurisdiction over non-Indian reservation activity).

216. See, e.g., South Dakota v. Bourland, 508 U.S. 679 (1993); see also Lauren Natasha Soll, The Only Good Indian Reservation Is a Diminished Reservation? The New and Diluted Canons of Construction in Indian Law, 41 FED. B. NEws \& J. 544 (1994).

217. See Mattz v. Arnett, 412 U.S. 481, 505 (1973) (ruling that congressional intent to terminate the existence of a reservation must "be expressed on the face of the Act or be clear from the 
misses the canons by declaring that no true ambiguity exists. For instance, Hagen $v$. Utah ${ }^{218}$ held that the Ute Indian reservation had been extinguished by statutes that opened some of it up to allotment. Hagen involved a 1902 Act that required tribal consent before allotments could be made, with the unallotted land to "be restored to the public domain."219 When consent was not forthcoming, Congress passed another Act in 1905 allowing allotments to be made without it. This later Act also eliminated the language restoring unallotted lands to the public domain.

The Hagen Court held that the vague phrase in the first Act about restoration to the public domain expressed congressional intent to disestablish the reservation. ${ }^{220}$ Next, it found that the 1905 Act not only effectuated allotment without Indian consent, but it also meant to restore unalloted lands to the public domain, a matter on which it was silent. ${ }^{221}$ After drawing these inferences-that restoration was tantamount to disestablishment and that the 1905 Act also removed the requirement of Indian consent to restoration-the Court found there was insufficient ambiguity to warrant applying the canons of construction. ${ }^{222}$ Thus, the Utes' reservation was extinguished.

\section{Nineteenth-Century Allotment Policy as the Touchstone for Congressional Intent}

In many of its recent cases, the Court has used the short-lived allotment policy as the touchstone for deciding how much governmental authority the tribes should exercise. ${ }^{223}$ The idea of carving up tribal lands into parcels owned by individual Indians originated in treaties. ${ }^{224}$ It became government policy in the late nineteenth century, when assimilationist fervor and non-Indian hunger for reservation lands reached

surrounding circumstances and legislative history"); see also DeCoteau v. District County Court, 420 U.S. 425, 444 (1975).

218. 510 U.S. 399 (1994).

219. Hagen, 510 U.S. at 403-04.

220. The majority read past cases as requiring a finding of diminishment wherever there is restoration language in subsequent legislation. Id. at 411-12. The dissent challenged the majority's interpretation of precedent. Id. at 428-29 (Blackmun, J., dissenting).

221. The Hagen dissent emphasized that Congress considered and rejected a proposal to include language in the subsequent act restoring the land to the public domain. Id. at 438-39. This and other criticisms of the Court's analysis are discussed in Judith V. Royster, The Legacy of Allotment, 27 ARIz. ST. L.J. 1 (1995).

222. Hagen, 510 U.S. at 420-21. Other courts grappling with the meaning of the two statutes found the issue less clear-cut. See, e.g., Pittsburg \& Midway Coal Mining Co. v. Yazzie, 909 F.2d 1387 (10th Cir. 1990); Ute Indian Tribe v. Utah, 773 F.2d 1087 (10th Cir. 1985); State v. Perank, 858 P.2d 927 (Utah 1992).

223. In a thorough study of the Court's treatment of the allotment policy, Professor Royster argues that "[o]ver the last two decades, under the activating hand of the Supreme Court, the policy has sprung back to life." Royster, supra note 221 , at 20 .

224. See CoHen (1982), supra note 2, at 127-38. 
a crescendo. Allotment would enable the governinent to inculcate in Indians the "habits of industry and civilization" that grow out of owning private property and pursuing the Jeffersonian ideal of the yeoman farmer. It would also free up tribal lands not allotted to individual Indians for white settlement, and remove control of land from tribal governunents that were considered subversive of progressive government policies. ${ }^{225}$ Part of the plan was to introduce non-Indians to the reservations, where they would serve as examples, inspiring the Indians to progress along the path to civilization. Within a generation or two the tribes would fade, the reservations would vanish, and Indians would be assimilated into the larger cominunity. ${ }^{226}$

The policy failed. Indians did not reject their cultural roots, even as many became landowners. The tribes struggled but survived, and reservations remained, albeit with large numbers of non-Indian occupants. ${ }^{227}$ These new arrivals had taken up hoinesteads on the surplus lands or had purchased parcels from. Indian allottees. The announced goals of the Allotinent Act were not realized, but an enormous amount of land passed into non-Indian hands. ${ }^{228}$

Congress expressly repudiated the allotment policy in 1934 . The Indian Reorganization $\mathrm{Act}^{229}$ which aimed at restoring autochthonous governing powers, outlawed further allotments and reinforced federal trust protection of reservation lands. ${ }^{230}$ For at least twenty years now, federal policy as expressed in congressional legislation and executive actions has been to support tribal self-determination. ${ }^{231}$ Although the Court has acknowledged this new policy, ${ }^{232}$ the Justices increasingly cite allotment-era policies in cases involving tribal sovereignty. Such cases have involved reservation diminishment, the scope of tribal authority in Indian country, and reservation Indians' immunity from state laws. The Hagen case discussed in the preceding subsection illustrates this phenomenon in a diminishment context.

In Montana v. United States, the Court took pains to effectuate what it thought Congress had envisioned for tribal jurisdiction over the

225. See Documents of United States Indian Policy, supra note 19, at 123-35.

226. See Readjustment of Indian Affairs: Hearings on H.R. 7902 Before the House Comm. on Indian Affairs, 73d Cong., 2d Sess. 428-89 (report of Delos S. Otis on the history of the allotment policy); see also supra text accompanying note 43.

227. See Stephen Cornell, The Return of the Native $80-82$ (1988).

228. See supra text accompanying note 42 .

229. 25 U.S.C. $\S \S 461-479$ (1994).

230. See generally Comment, Tribal Self-Government and the Indian Reorganization Act of 1934, 70 MrCH. L. REv. 955 (1972).

231. See, e.g., Indian Self-Determination and Education Assistance Act of 1975, 25 U.S.C. \& 450; Indian Financing Act of 1974, 25 U.S.C. §§ 1451-1454; see also supra text accompanying notes 77-85.

232. See California v. Cabazon Band of Mission Indians, 480 U.S. 202, 217 (1987); New Mexico v. Mescalero Apache Tribe, 462 U.S. 324, 334-35 (1983). 
reservations when it passed the Allotment Acts. Going deep into the legislative history, Justice Stewart's majority opinion gave currency to the goal of "eventual assimilation of the Indian population." cited nineteenth-century reports, cases, and legislative history ${ }^{234}$ to show that it would go against the contemporary federal policy to allow the Crow Tribe to control hunting and fishing on non-Indian lands within their reservation:

[T] he allotment policy was designed to eventually eliminate tribal relations .... [T] [Te "civilization" of the Indian population was to be accomplished, in part, by the dissolution of tribal relations ....

There is simply no suggestion in the legislative history that Congress intended that the non-Indians who would settle upon alienated allotted lands would be subject to tribal regulatory authority. ${ }^{235}$

Just thirteen years earlier, in Menominee Tribe of Indians v. United States, ${ }^{236}$ the Court had specifically rejected using implications drawn from repudiated legislation as "a backhanded way of abrogating the hunting and fishing rights of ... Indians."237 Although the entire Menominee Reservation had been abolished under the Termination Act of $1954,{ }^{238}$ the Court held that Indian hunting and fishing rights were preserved on former reservation lands by an 1854 treaty. ${ }^{239}$ The Court applied an established principle of Indian law that "the intention to abrogate or modify a treaty is not to be lightly imputed to the Congress."240 Justice Stewart dissented in Menominee, arguing that the Termination Act implicitly abrogated treaty rights. ${ }^{241}$ He did not even cite the case in his majority opinion in Montana.

In Brendale v. Confederated Tribes \& Bands of the Yakima Indian Nation, ${ }^{242}$ the opinions of Justices White and Stevens also breathed new life into the Allotment Act. White cited Montana as controlling, quoting

233. Montana v. United States, 450 U.S. 544,559 n.9 (1981).

234. The Court's use of history has been aptly criticized elsewhere. See, e.g., Robert N. Clinton, The Curse of Relevance: An Essay on the Relationship of Historical Research to Federal Indian Litigation, 28 ARIz. L REv. 29 (1986).

235. Montana, 450 U.S. at 560 n.9.

236. 391 U.S. 404 (1968).

237. Id. at 412 .

238. 25 U.S.C. $\$ \$ 891-902$ (repealed 1973).

239. The 1854 Treaty of Wolf River did not expressly establish those rights; it stated only that the lands were "to be held as Indian lands are held." Menominee, 391 U.S. at 405-06. That the Indians had a "way of life which included hunting and fishing" was enough for the Court to infer that the Indians' rights were undiminished by the treaty. $I d$.

240. Id. at 413 (quoting Pigeon River Improvement, Slide \& Boom Co. v. Charles W. Cox, Ltd., 291 U.S. 138, $160(1934)$ ).

241. Id. at 416 (Stewart, J., dissenting).

242. 492 U.S. 408 (1989). 
the proposition that "[i]t defies common sense to suppose that Congress would intend that non-Indians purchasing allotted lands would become subject to tribal jurisdiction when an avowed purpose of the allotment policy was the ultimate destruction of tribal government."243 In a separate opinion, Stevens wrote that the Allotment Act "to some extent reworked fundamental notions of Indian sovereignty."244 He found that the tribe's authority over the reservation was abrogated because it was "improbable that Congress envisioned that the Tribe would retain its interest in regulating the use of vast ranges of land sold in fee to nonmembers who lack any voice in setting tribal policy."245 Though White and Stevens disagreed on the Allotment Act's effect in Brendale, both considered it the Court's mission to realize the goals of that congressionally rejected century-old policy.

The allotment policy was reinvigorated to extend state power over Indians in County of Yakima v. Confederated Tribes \& Bands of the Yakima Indian Nation. ${ }^{246}$ Although Congress had allowed only a narrow class of allotments to be taxed, the Court held that all Indian-owned allotments in fee on the reservation were subject to state taxation. ${ }^{247}$ The state's taxing authority was expressly limited to allotments patented in fee to Indians found "competent and capable" under section 6 of the Act. ${ }^{248}$ The Act said nothing about whether allotments routinely patented in fee to Indians at the expiration of a statutory trust period under section 5 were also taxable. The Court read the limited consent to taxation broadly so as to implement the general assimilationist purpose of the Allotment Act.

In the 1976 case of Bryan v. Itasca County, ${ }^{249}$ the Court rejected the present compulsion to resuscitate the old policy of allotment, holding that "courts 'are not obliged in ambiguous instances to strain to implement [an assimilationist] policy Congress has now rejected, particularly where to do so will interfere with the present congressional approach to what is, after all, an ongoing relationship." 250 In Bryan, the Court narrowly read a statute allowing certain states to assert civil jurisdiction in Indian country. It moderated the clearly assimilationist

243. Id. at 423 (citing Montana, 450 U.S. at $559-60 \mathrm{n} .9$ ).

244. Id. at 436; see also supra notes 193-194.

245. Brendale, 492 U.S. at 437 . However, Stevens also found it "inconceivable that Congress would have intended that the sale of a few lots would divest the Tribe of the power to determine the character of the tribal community." Id.

246. 502 U.S. 251 (1992).

247. See id. at 266-69.

248. Id. at $258 \mathrm{n} .1$.

249. 426 U.S. 373 (1976).

250. Id. at 388-89 n.14 (quoting Santa Rosa Band of Indians v. Kings County, 532 F.2d 655, 663 (9th Cir. 1975)). 
purpose of the statute with the self-determination goals of an amendment that was not directly involved in the case. ${ }^{251}$

Courts are not, of course, so bound by today's self-determination policy that they can ignore the words of an assimilationist statute still on the books. But when the statute is not dispositive because it fails to address the situation in question, as in Yakima, the Court should look to the larger context of federal law to define concepts like tribal sovereignty, Indian immunity, and the trust relationship. It is inappropriate for the Court to animate a rejected policy, simply because the case may . involve one or more provisions passed in the former era. Yet that is what the Court has been doing, filling gaps in legislation and construing tribal sovereign powers in accordance with allotment-era goals merely because some or all of a reservation has been allotted.

\section{Fabrication of a "Balancing of Interests" Test}

Some scholars have tried to synthesize the Court's recent Indian law jurisprudence into a test that "balances" the interests of state, federal, and tribal governments. ${ }^{252}$ Indeed, a few of the Court's most recent decisions explicitly refer to an interest-balancing approach, citing the McClanahan line of cases. ${ }^{253}$ At best, this reflects a misunderstanding of the cases cited. At worst, it is disingenuous. The established role of Indian law preemption analysis is not to collect ingredients for ad hoc judicial balancing, but to ensure that interpretations of congressional intent comport with a legal tradition that perpetuates tribal selfgovernment.

The confusion about balancing interests traces back to Justice Marshall's opinion for the Court in McClanahan. In the decision, which barred states from taxing the income of reservation Indians, Marshall summarized Supreme Court jurisprudence, recognizing that it had modified the absolute bar on state authority in Indian country only to the extent necessary "to take account of the State's legitimate interests in regulating the affairs of non-Indians." ${ }^{.254} \mathrm{He}$ cited Williams

251. See id. at 386-87. The amendment, in Title IV of the Indian Civil Rights Act of 1968, 25 U.S.C. $\$ \S 130 \mathrm{I}-\mathrm{I} 341$, required that tribes consent to any additional extensions of state jurisdiction over Indian country under Public Law 280.

252. See, e.g., Jordan Burch, How Much Diversity Is the United States Really Willing to Accept?, 20 Ohlo N.U. L. Rev. 957, $964-69$ (1994); William W. Fisher, III, The Jurisprudence of Justice Marshall, 6 HARv. BlackLetter J. 131, 136-37 (1989); Judith V. Royster \& Rory SnowArrow Fausett, Control of the Reservation Environment: Tribal Primacy, Federal Delegation, and the Limits of State Intrusion, 64 WASH. L. REv. 581, 649-57 (1989).

253. See, e.g., Department of Taxation \& Fin. v. Milhelm Attea \& Bros, 114 S. Ct. 2028, 2035 (1994); County of Yakima v. Confederated Tribes \& Bands of Yakima Indian Nation, 502 U.S. 25l, 257 (1992).

254. McClanahan, 411 U.S. at 171. 
v. Lee, ${ }^{255}$ which prevented a state court from hearing a non-Indian's action to collect a debt incurred by a tribal member on the reservation. There, the Court asked "whether the state action imfringed on the right of reservation Indians to make their own laws and be ruled by them."256

In both McClanahan and Williams, the state had an "interest" in asserting its jurisdiction. However, Marshall explained that because tribal governance of Indian conduct or property was affected, application of state law interfered with tribal self-government and the state's interests-vigorously asserted in McClanahan-would not be considered. ${ }^{257} \mathrm{McClanahan}$ made clear that state interests would only be a factor in determining whether Congress intended to preempt state law in cases involving non-Indians. ${ }^{258}$ Marshall never said that weighing or balancing state interests against tribal interests was appropriate, nor did he suggest even a consideration of state interests in cases involving Indians and their property. His dictum was simply that the cases allowing state jurisdiction can be explained as ones in which state interests in controlling non-Indian conduct or property were so great that the usual presumption of preemption of state law in Indian country could be overcome "up to the point where tribal self-government would be affected."259

In White Mountain, Justice Marshall's majority opinion blurred McClanahan's mention of interests, generalizing that cases involving non-Indians call for "a particularized inquiry into the nature of state, federal, and tribal interests at stake, an inquiry designed to determine whether, in the specific context, the exercise of state authority would violate federal law."260 This statement of the test may have been an at-

255. 358 U.S. 217 (1959).

256. McClanahan, 411 U.S. at 172 (quoting Williams, 358 U.S. at 220).

257. Id. at $180-81$.

258. "It must be remembered that cases applying the Williams test have dealt principally with situations involving non-Indians. In these situations, both the tribe and the State could fairly claim an interest in asserting their respective jurisdictions. The Williams test was designed to resolve this conflict by providing that the State could protect its interest up to the point where tribal selfgovernment would be affected." Id. at 179 (citations omitted).

The cases relied on in Williams and McClanahan only support consideration of non-Indian interests in situations that do not involve Indian conduct. The cases allow: (1) a State to try a nonIndian for murdering another non-Indian on a reservation, see New York ex rel. Ray v. Martin, 326 U.S. 496 (1946); Draper v. United States, 164 U.S. 240 (1896); United States v. McBratney, 104 U.S. 621 (1881); (2) Indians to sue non-Indians in state court, see United States v. Candelaria, 271 U.S. 432 (1926); Felix v. Patrick, 145 U.S. 317 (1892); and (3) a State to tax non-Indian property on a reservation, see Utah \& N. Ry. v. Fisher, 116 U.S. 28 (1885). See also McClanahan, 411 U.S. at 171; Williams, 358 U.S. at 219-20. An example of state court jurisdiction over non-Indians that Williams and McClanahan overlooked is state service of process to non-Indians in Indian country. See Langford v. Monteith, 102 U.S. 145 (1880); see also supra text accompanying note 66.

259. McClanahan, 411 U.S. at 179.

260. White Mountain, 448 U.S. at 145. 
tempt to win over members of the Court who wanted greater freedom to shape outcomes.

Perhaps Marshall should have anticipated that in the hands of others, his device for statutory interpretation would become a judicial "balancing of interests" test. Several members of the Court have expressed uneasiness with "Indian rights" and seem to favor assimilating tribes into the mainstream. ${ }^{261}$ These Justices have used White Mountain's "particularized inquiry" to balance interests and reach outcomes consistent with their own notions of how much tribal autonomy there ought to be. ${ }^{262}$

The idea that White Mountain invites interest balancing appears in Justice Stewart's dissent in Central Machinery, which was joined by Powell, Stevens, and Rehnquist. Stewart criticized the majority for not following the "settled teaching of the Court's [Indian law] decisions ... that every relevant state interest is to be given weight."263 $\mathrm{He}$ insisted that "limits inherent in the principles of federal preemption ... [necessitate] a careful inquiry into pertinent federal, tribal, and state interests, without which a rational accommodation of those interests is not possible."264

This point of view was elevated to doctrine in 1994 in Department of Taxation \& Finance v. Milhelm Attea \& Bros. ${ }^{265}$ That decision represents the first time the Court expressly resolved a case through interest balancing. Milhelm allowed New York to tax purchases of cigarettes by tribal retailers that exceeded the state's estimate of reservation Indians' own "probable demand" for cigarettes. New York's scheme was a response to the state's continuing difficulties in enforcing its tax on reservation cigarette sales to non-Indians. Some Indian smokeshops continued to thrive in New York and elsewhere, largely because state taxes were not collected. Moe and Colville allowed states to require Indian sellers to collect the taxes and report sales according to the race and tribal affiliation of purchasers. ${ }^{266}$ However, in 1991, the Supreme

261. See, e.g., Lyng v. Northwest Indian Cemetery Protective Ass'n, 485 U.S. 439, 455 (1988); Oregon Dep't of Fish \& Wildlife v. Klamath Indian Tribe, 473 U.S. 753, 774 (1985); Washington v. Washington State Commercial Passenger Fishing Vessel Ass'n, 443 U.S. 658, 699 n.3 (1979); see also supra text accompanying note 187 (discussing Brendale).

262. In White Mountain, Justice Stevens considered the financial burden imposed on the Indians by state taxation of tribal contractors and concluded that "these relatively trivial taxes" were "unlikely to have a serious adverse impact on the tribal business." 448 U.S. at 159 (Stevens, J., dissenting). The Colville majority took a similar approach, relying on a finding that retail sales of cigarettes to outsiders are not "activities in which the Tribes have a significant interest." 447 U.S. at 155.

263. Central Machinery Co. v. Arizona State Tax Comm'n, 448 U.S. 160, 170 (1980) (Stewart, J., dissenting).

264. Id.

265. 114 S.Ct. 2028 (1994).

266. See supra notes $120,126$. 
Court clarified that a state could not proceed by suing tribes for damages because Indian tribes were immune from suit. ${ }^{267}$ Instead, the Court suggested other means by which the tax might be collected: the state could sue individual tribal officers, shipments of untaxed cigarettes might be seized en route to the reservation, or taxes might be assessed directly against wholesalers who sell to reservation dealers. ${ }^{268}$ The Court also noted that states could negotiate cooperative tax collection agreements with tribes. ${ }^{269}$ It concluded by pointing out that if states "find that none of these alternatives produce the revenues to which they are entitled, they may of course seek appropriate legislation from Congress." 270

These options did not satisfy the states. ${ }^{271}$ Rather than seek redress from Congress, they began to pursue collection methods that involved more extensive assertions of jurisdiction in Indian country. New York's scheme was the most aggressive. By imposing quotas on every sale and delivery of untaxed goods shipped to the reservation based on the state's determination of the "probable demand" for cigarettes by Indians, it could effectively control tribal trade. Yet the Supreme Court reversed a New York Court of Appeals decision that found that the scheme conflicted with the federal trader statutes. ${ }^{272}$

The Court invoked no principle for its extension of state jurisdiction over reservation Indians in Milhelm. ${ }^{273}$ It simply stated that the

267. See Oklahoma Tax Comm'n v. Citizen Band Potawatomi Indian Tribe, 498 U.S. 505, 509514 (1991).

268. Id. at 514. If the particular tribe exercised civil jurisdiction over such matters, suits against individual officers would have to be litigated in tribal courts. See National Farmers Union Ins. Cos. v. Crow Tribe of Indians, 471 U.S. 845,857 (1985).

269. The Supreme Court has suggested that state tax collection agreements with tribes are permitted under 25 U.S.C. $\S 476$. Potawatomi, 498 U.S. at 514. Agreements between tribes and states could be made on a number of subjects. See James A. Casey, Note, Sovereignty by Sufferance: The Illusion of Indian Tribal Sovereignty, 79 CORNELL L. REv. 404, 447 (1994).

270. Potawatomi, 498 U.S. at 514.

271. See Joanne Furio, Shinnecocks Face Tax on Cigarettes, N.Y. TimEs, March 5, 1989, §12LI, at 11. Collecting the sales tax in advance from the wholesalers would simply cause the tribe to buy from out-of-state wholesalers beyond the reach of the state's taxing authority. Imposing the tax on all sales made by in-state wholesalers would lead out-of-state retailers to buy cigarettes from untaxed wholesalers in other states. Seizing untaxed cigarettes en route to the reservation is problematic because some of the cigarettes inay be destined for non-taxable sales to Indians. Seizures from nonIndian purchasers leaving the reservation would be costly and politically unpopular.

272. Department of Taxation \& Fin. v. Milhelm Attea \& Bros, 114 S. Ct. 2028, 2033 (1994).

273. The Court opined that Warren Trading Post Co. v. Arizona State Tax Commission, 380 U.S. 685 (1965), considered to be the bedrock case of the modern era in Indian law, had been "undermined" by recent decisions. 114 S.Ct at 2034 (citing Central Machinery, 448 U.S. at 172 (Powell, J., dissenting)). The Central Machinery decision actually reaffirmed Warren Trading Post, strongly proclaiming that Congress had so fully regulated Indian trading that there was no room for state regulation of reservation sales to Indians. The Powell dissent to which Milhelm referred argued that Warren had been undermined by Moe and Colville, both of which allowed states to require Indian retailers to collect taxes on sales to non-Indians. Moe and Colville, to be sure, are a departure from the previously established principle that any burden on licensed Indian traders not authorized by 
“"balance of state, federal, and tribal interests' in this area thus leaves more room for state regulation than in others."274 The decision effectively sanctioned state regulation of commerce with Indian tribes, a matter historically and constitutionally reserved to Congress. ${ }^{275}$

In 1995, the Court went even further. In Oklahoma Tax Commission v. Chickasaw Nation, ${ }^{276}$ the Court characterized its approach to state regulation of Indian activities in Indian country as "balancing interests." Never before had the Court allowed consideration of state interests-and certainly not a balancing of interests-in a case involving Indian activity on the reservation. ${ }^{277}$ Balancing social values and political effects on Indians and non-Indians to reach an "acceptable" result may indeed be what has influenced many Justices to vote as they have, as I posit in this Article. It is not, however, what the opinions have proclaimed. Now the Court seems ready to institutionalize a subjective approach by explicitly adopting a balancing test. Some Justices are even willing to balance interests in situations where state jurisdiction should simply be out of the question, such as the regulation of Indians in Indian country.

\section{III}

\section{A New Supreme Court and the Future of Indian Law}

During their time on the Court, Justices Brennan, Marshall, and Blackmun were generally loyal to the tradition of respecting tribal rights and sovereignty as subject only to congressional modification. ${ }^{278}$ Justices Marshall and Brennan wrote a disproportionately large number of the key Indian decisions of the modern era, including about a third of all Indian decisions between 1973 and 1983.279 Justice Blackmun usually joined with Marshall and Brennan on sovereignty-related

Congress is prohibited. However, at least the imposition on Indians in those cases could be rationalized as a "minimal burden." See Moe, 425 U.S. at 483.

Milhelm's departure from Warren Trading Post is much more substantial. The majority also sought the support of Moe and Colville, but this time the Court recast Colville as authorizing a "comprehensive ... enforcement scheme that required tribal retailers . . . to keep extensive rccords." Milhelm, 1 I4 S. Ct. at 2034-35. Milhelm represented the two cases as legitimizing a far more intrusive regulation than the "minimal burden" first contemplated in Moe.

274. Milhelm, 114 S. Ct. at 2035-36 (quoting Rice v. Rehner, 463 U.S. 7I3, 720 (1983)).

275. See Warren Trading Post, 380 U.S. at 686.

276. 115 S. Ct 2214 (1995).

277. See id. at 2220 (citing Cabazon, 480 U.S. 202, 216-I7 (1987); Moe, 425 U.S. 463, 483 (1976)).

278. All three have on occasion voted to deny tribal sovereignty: Blaclmun joined majorities in Oliphant v. Suquamish Indian Tribe, 435 U.S. 191, 192 (1978), and Colville, 447 U.S. at I37; Brennan, Blackmun, and Marshall all joined Justice Rehnquist's unanimous opinion for the court in Moe, 425 U.S. at 465.

279. Marshall wrote ten and Brennan wrote seven of the Court's 47 Indian law opinions from that period. 
cases. ${ }^{280}$ Blackmun, however, wrote very few Indian law opinions in his twenty-four year career ${ }^{281}$ and voted with the majority in Duro to deny tribal jurisdiction over non-members. Then, upon the departure of his foundationalist colleagues, he became a frequent dissenter against the emerging subjectivist trend, writing strong opinions in cases where the majority ignored foundation principles. ${ }^{282}$

Now that Marshall, Brennan, and Blackmun have all left the Court, only Chief Justice Rehnquist and Justice Stevens have demonstrated any serious interest in Indian cases. Neither adheres to the traditional view that the judiciary should leave modifications of tribal sovereignty to Congress. Indeed, both have taken a subjectivist approach, rolling back Indian sovereignty if they believe it portends cultural conflict.

Four other Justices gravitate to a "sensible" outcome that diminishes tribal sovereignty whenever non-Indian activities, social values, or property interests are sufficiently impacted. These Justices vary in the degree of cultural abrasion they will tolerate, but all are content to recite subjectivist grounds for their decisions, showing no allegiance to foundation principles. Three of the four newest Justices have not clearly revealed their direction in Indian cases. None appears particularly committed to or interested in articulating a coherent doctrine in the field, though each has the potential to take a leadership role. One or more of the new Justices-or future appointees-could steer doctrine back on track using foundation principles by taking responsibility, as Justice Thurgood Marshall did, for writing a large number of opinions based on consistent principles whenever a majority supports the outcome.

A review of the record of individual Justices on the current Court is useful in assessing the prospects of a revival of foundation principles in Indian law.

280. Blackmun disagreed with Marshall in several Indian cases. See, e.g., Colville, 447 U.S. at 134; Puyallup Tribe, Inc. v. Department of Game, 433 U.S. 165 (1977); Rosebud Sioux Tribe v. Kneip, 430 U.S. 584 (1977); Colorado River Water Conservation Dist. v. United States, 424 U.S. 800 (1976); DeCoteau v. District County Court, 420 U.S. 425 (1975).

Blackmun also disagreed with Brennan in several cases. See e.g., Duro v. Reina, 495 U.S. 676 (1990); Three Affiliated Tribes v. Wold Eng'g, 476 U.S. 877 (1986); South Carolina v. Catawba Indian Tribe, Inc., 476 U.S. 498 (1986); Oregon Dept. of Fish \& Wildlife v. Klamath Indian Tribe, 473 U.S. 753 (1985); Washington v. Confederated Bands \& Tribes of Yakima Indian Nation, 439 U.S. 463 (1979); DeCoteau, 420 U.S. at 425; Mescalero Apache Tribe v. Jones, 411 U.S. 145 (1973).

281. Justice Blackmun wrote five majority opinions, eight dissents, and five concurrences. His most important dissents were County of Yakima v. Confederated Bands \& Tribes of Yakima Indian Nation, 502 U.S. 25 I (1992), Cotton Petroleum Corp. v. New Mexico, 490 U.S. 163 (1989), and Rice v. Rehner, 463 U.S. 713 (1983). His most important majority opinions were United States v. John, 437 U.S. 634 (1978), Morton v. Mancari, 417 U.S. 535 (1974), and Morton v. Ruiz, 415 U.S. 199 (1974).

282. See, e.g., Hagen v. Utah, 510 U.S. 399, $422-42$ (1994); South Dakota v. Bourland, 508 U.S. 679, 698-704 (1993); County of Yakima, 502 U.S. at 270-278. But see Department of Taxation \& Fin. v. Milhelm Attea \& Bros., 114 S. Ct. 2028 (1994) (joining a unanimous Court). 


\section{A. The Justices}

\section{Chief Justice Rehnquist}

Of all the sitting Justices, Chief Justice William H. Rehnquist has had the greatest influence on Indian law. His impact is more profound than even his seniority on the Court would suggest. ${ }^{283}$ In 1974, two years after he was appointed to the Court, Justice Rehnquist began taking an active role in Indian cases, writing eight majority opinions and four dissents in the following eight years. Although some attribute his presence in the field in those years to his relatively junior status and a fabled unpopularity of Indian cases among the Court's members, ${ }^{284}$ the degree of vigor with which he has asserted his views in Indian law belies a perfunctory or obligatory exercise. His spirited opinions arguing for an historical review of facts to guide construction of Indian statutes have

283. See generally Ralph W. Johnson \& Berrie Martinis, Chief Justice Rehnquist and the Indian Cases, 16 Pub. Land L. Rev. 1, 24 (1995) ("Rehnquist's ideas about Indian law, coupled with his position as Chief Justice, have had grave implications for Indian sovereignty and welfare.... Rehnquist is advocating and implementing a judicial termination policy.").

284. Woodward and Armstrong believe that "Rehnquist had nothing but contempt for Indian cases." Bob Woodward \& SCOTt ARMSTRong, The BREThren: INSIDE the SUPREME COURT 412 (1979). They surmise that, as a westerner, he was naturally viewed by the others as a logical replacement for William $O$. Douglas, the Court's in-house Indian law expert. They accurately noted that in Moe, he "turned an opinion that was in favor of the Indians into an opinion that indicated that in most cases they would lose." Id.

Woodward and Armstrong imply that Douglas was friendlier to Indians, stating that Rehnquist's opinion "wiped away decades of Douglas's opinions." Id. In reality, though, Douglas favored Indians only when their interests overlapped with other, higher concerns of his such as civil rights. He sharply curbed Indian rights, going against established doctrine, when he feared that tribal sovereignty would clash with his preference for wildlife conservation. In Puyallup Tribe v. Department of Game, 391 U.S. 392 (1968), he allowed Indian treaty fishing rights to be subjected to state regulation when a state court decided its laws were "reasonable and necessary" for conservation. Id. at 401. Earlier case law had protected treaty fishing from state control. One critic of Douglas' extension of state jurisdiction declared that "[n]o valid basis for the existence of such state power ean be found." Ralph W. Johnson, The States Versus Indian Off-Reservation Fishing: A United States Supreme Court Error, 47 WASH. L REv. 207, 208 (1972).

Although Douglas wrote some opinions that favored tribal sovereignty (e.g., his dissent in Mescalero), nothing in his jurisprudence suggests a pro-Indian bias. He initially voted to deny tribes power to regulate reservation liquor licensing in Mazurie, only later reluctantly joining in Rehnquist's opinion favoring the tribe. See Memorandum from Justice William O. Douglas to Justice William H. Rehnquist (Dec. 21, 1974) (United States v. Mazurie, No. 73-1018), in Marshall Papers, supra note 4. Furthermore, his privately expressed views suggest some discomfort with Indian sovereignty. After seeing Marshall's draft opinion in McClanahan, Douglas implored his colleague to remove part of the basic discussion of tribal powers, now found in 411 U.S. at 171-73, "because the word 'Indian' is an elusive term .... In my State a person is a Yakima Indian if he has 1/64 [degree Indian blood], and most of the tribe now have blue eyes and golden hair." Memorandum from Justice William $O$. Douglas to Justice Thurgood Marshall (Feb. 7, 1973) (McClanahan v. Arizona Tax Comm'n, No. 71 834), in Marshall Papers, supra note 4. 
been especially significant. Such opinions include Oliphant ${ }^{285}$ and his dissents in Central Machinery ${ }^{286}$ and Ramah. ${ }^{287}$

Rehnquist designed a kind of subjectivism not embraced by other Justices in their opinions. His theory was based on a unique view of how to apply McClanahan's preemption test. Justice Marshall established in that case that the "Indian sovereignty doctrine" remained the "backdrop" in analyzing whether Indian treaties and federal statutes preempted state law. ${ }^{288}$ Rehnquist first laid out his own version of this "tradition of sovereignty" in a separate opinion in Colville. ${ }^{289}$

In Colville, Rehnquist maintained that if the Court would simply look to historical perceptions of taxing power on reservations there would be "no need ... to balance the state and tribal interests in enacting particular forms of taxation in order to determine their validity." 290 He urged that early notions of tribal powers and immunities as reflected in historical records, generally reporting the perceptions of non-Indians, should determine the outcomes. Thus, unless a review of historical information showed actual tribal exercise of the specific type of jurisdiction, Rehnquist would require an act of Congress to preempt state law. In a situation like Colville, "[w] hen tradition did not recognize a sovereign immunity in favor of the Indians, this Court [sh]ould recognize one only if Congress expressly conferred one."291 Requiring that stat-

285. Oliphant v. Suquamish Indian Tribe, 435 U.S. 191 (1978).

286. Central Machinery Co. v. Arizona State Tax Comm'n, 448 U.S. 160, 166-70 (1980) (Rehnquist, J., dissenting).

287. Ramah Navajo Sch. Bd., Inc. v. Bureau of Revenue, 458 U.S. 832, 847-57 (1982) (Rehnquist, J., dissenting).

288. McClanahan, 411 U.S. at 172.

289. In earlier cases Rehnquist used a preemption analysis essentially like Marshall's in McClanahan. His unanimous opinion in Moe, 425 U.S. 463 (1976), had upheld immunity of Indians from state tobacco taxes but allowed the state to tax reservation sales to non-Indians. Furthermore, the first Indian opinion he authored, United States v. Mazurie, 419 U.S. 544 (1975), was a straightforward statement of preemption doctrine that acknowledged the propriety of federal delegation of liquor licensing authority to tribes, even over non-Indians, in part because "Indian tribes are unique aggregations possessing attributes of sovereignty over both their members and their territory." Id. at 557. He did not seem in doubt about what Marshall and the Court meant in McClanahan. This may be explained by the fact that McClanahan was Rehnquist's introduction to Indian law as a new Justice on the Court.

in the 1977 Term, Justiee Rehnquist starting using historical events and non-indian perceptions as determinants of the boundaries of tribal sovereignty. His opinion in Oliphant relied primarily upon a "commonly shared presumption" of government entities, 435 U.S. at 206, and that it would be "inconsistent with their status for tribes to exercise criminal jurisdiction over non-Indians." Id. at 208. Then, in Colville, Rehnquist tried his novel interpretation of the tradition of sovereignty. 447 U.S. at 134.

290. 443 U.S. at 177.

291. Id. at 179 (emphasis in original). As discussed supra note 143 and accompanying text, Rehnquist's separate opinion in Colville was originally written as a dissent from Justice Brennan's draft majority opinion favoring broad tribal tax immunity. See First Draft Colville Opinion, supra note 127. Rehnquist reworked his old dissenting opinion to challenge Justice White's majority opinion (whose result he accepted) for its failure to apply his idiosyncratic view of the tradition-of- 
utes and treaties expressly rebut limitations on tribal sovereignty implied from historical practice and perceptions would, in his view, eliminate the need for considering various governmental interests, making matters simpler. ${ }^{292}$

Searching for historical evidence of limits on Indian sovereignty to chart the contours of modern Indian sovereignty was, in essence, the way the Court reached its result in Oliphant. Rehnquist, the author of Oliphant, did not cite it in his Colville concurrence. But both opinions indulged in a search for historical indicators as to how Indian sovereignty should be treated, rather than a search for congressional limitations. In Oliphant, "shared assumptions" by government officials about the nature of tribal powers provided a basis for finding an inherent limitation on tribal powers that supposedly had existed ever since the founding of the nation.

Now, Rehnquist appears to be content to join in subjectivist opinions that balance interests. Since he became Chief Justice in 1986, he has relied on Justices Stevens and O'Connor to write most Indian opinions for the majority (four each). Rehnquist himself has only written two majority opinions in the last ten years. ${ }^{293}$ Rehnquist seems to have given up on swaying others to his novel version of the preemption approach, and his dissents are fewer, as they are in all fields. Apparently he is exercising the statesmanship he considers appropriate for a Chief Justice. His greatest influence in future Indian cases will likely be through the assignment of opinions to be written by Associate Justices.

\section{Justice Stevens}

Justice John Paul Stevens came on the Court in 1975. Before 1985, he authored only three Indian law majority opinions, albeit important ones. $^{294}$ Within the next ten years he wrote another seven majority

sovereignty component of the preemption analysis. Rehnquist found no "tradition" to support immunity from state tax because an old case, Thomas v. Gay, 169 U.S. 264 (1898), allowcd a state to tax cattle grazed by a non-Indian on a reservation. Colville, 447 U.S. at 183-84.

292. Colville, 447 U.S. at 176. Notwithstanding his professed distaste for a "balancing" approach, he joined a dissenting opinion in Central Machinery about two weeks after Colville, insisting that the majority had not given enough weight to state interests in taxing a reservation transaction as required by McClanahan and other cases. Central Machinery, 448 U.S. at 170.

293. See Seminole Tribe v. Florida, 116 S. Ct. 1114 (1996); Oklahoma Tax Comm'n. v. Citizen Band Potawatomi Indian Tribe, 498 U.S. 505 (1991). Seminole involved the tribal right to sue states under the Indian Gaming Regulatory Act. Although it involved an Indian tribe and parsed an Indian statute, the majority and two dissenting opinions were preoccupied with the broader constitutional question of the circumstances under which Congress can legislate a waiver of a state's immunity from suit.

294. Washington v. Washington State Commercial Passenger Fishing Vessel Ass'n, 443 U.S. 658 (1979); Puyallup Tribe, Inc. v. Department of Game, 433 U.S. 165 (1977). The Marshall Papers reveal that he was also the author of the per curiam opinion in Fisher v. District Court, 424 U.S. 382 (1976) (affirming tribal sovereignty over a child placement case). At that time, he had been seated 
opinions, exerting significant influence on the Court's current Indian law jurisprudence. Stevens has put his own brand on Indian law, arguing continually against the sovereignty and special status of tribal governments. ${ }^{295}$ In a series of cases, Stevens and Rehnquist took turns expressing their minority view that the preeinption analysis should not begin with a presumption in favor of preempting state law in Indian country. Dissenting in White Mountain, Stevens cited the "general rule" against finding preemption in state taxation cases, ${ }^{296}$ and in his dissent in Merrion he expounded upon the limited power of Indian tribes to enact legislation affecting non-members. ${ }^{297}$ Though he was not successful in swaying the inajority to his view in cases involving only Indians, in Cotton Petroleum he was able to espouse his view in a majority opinion for a case involving non-Indians. ${ }^{298}$

More than any other meinber of the Court, Stevens has followed a subjectivist approach to tribal jurisdiction questions, typified by his opinions in Cotton Petroleum, Brendale ${ }^{299}$ Milhelm, ${ }^{300}$ and several of his dissents. ${ }^{301}$ His approach exemplifies what Justice Scalia meant when he described the Court's Indian law jurisprudence as an attempt "to discern what the current state of affairs ought to be. ${ }^{n 302}$ He has no allegiance to the foundation principles drawn from two centuries of the Court's Indian law decisions. Synthesized, those principles say that tribes have sovereignty in Indian country except to the extent Congress, by treaty or statute, modifies their powers or alters the tribe's relation-

on the Court for less than two months. Memorandum from Justice Thurgood Marshall to Justice John Paul Stevens (Feb. 19, 1976) (Fisher v. District Court, No. 75-5366), in Marshall Papers, supra note 4. During this same period Stevens wrote one concurrence, see Montana v. United States, 450 U.S. 544, 567 (1981), and four dissents, see County of Oneida v. Oneida Indian Nation, 470 U.S. 226 (1985); Merrion v. Jicarilla Apache Tribe, 455 U.S. 130 (1982); White Mountain Apache Tribe v. Bracker, 448 U.S. 136 (1980); Delaware Tribal Business Comm. v. Weeks, 430 U.S. 73 (1977).

295. Professor Tsosie criticizes Stevens' "restrictive analysis of tribal sovereignty." Rebecca Tsosie, Separate Sovereigns, Civil Rights, and the Sacred Text: The Legacy of Justice Thurgood Marshall's Indian Law Jurisprudence, 26 ARIz. ST. L.J. 495, 511-13 (1994).

296. White Mountain, 448 U.S. at 159.

297. Merrion, 455 U.S. at 159-90. In Ramah, he joined Rehnquist in deploring the majority's result that accorded a tribe "greater tax immunity than it accorded . . the United States." 458 U.S. at 847.

298. Cotton Petroleum Corp. v. New Mexico, 490 U.S. 163, 187 (1989).

299. 492 U.S. 408 (1989).

300. 512 U.S. 61 (1994).

301. See Mississippi Band of Choctaw Indians v. Holyfield, 490 U.S. 30 (1989) (argning that parents domiciled on a reservation should be able to avail themselves of state adoption procedures); California v. Cabazon Band of Mission Indians, 480 U.S. 202 (1987) (Indian-managed gambling operations are suhject to state law absent explicit evidence of congressional intent to exempt the activity); Merrion v. Jicarilla Apache Tribe, 455 U.S. 130 (1982) (tribal powers to tax non-members on reservations are limited); White Mountain Apache Tribe v. Bracker, 448 U.S. 136 (1980) (state taxes of activities by non-members on reservation are not preempted absent explicit congressional intent to the contrary).

302. See Scalia Duro Memo, supra note 4. 
ship to the United States government. As discussed above, ${ }^{303}$ an ad hoc judicial weighing of demographic facts to design an Indian policy each time a case reaches the Court creates serious practical problems for those who must execute and enforce the law. ${ }^{304}$ No case better exemplifies this problem than the jurisdictional crazy-quilt created by Brendale where Stevens' preferred result became the rule. ${ }^{305}$

Justice Stevens' inclination toward subjectivism may be reconciled with his approach to other legal issues. He reportedly sees the Court as having a "broad mandate to promote freedon, equal opportunity, ... and to hold the government to a high standard of fairness in dealing with citizens." ${ }^{306}$ His concern with government accountability and procedural fairness also explains almost all of those exceptional cases in which his opinions are apparently sympathetic to the positions of Indian litigants. ${ }^{307}$

303. See supra text accompanying notes 186-188.

304. See supra text accompanying notes 189-192. But see Peter W. Sly, EPA and Indian Reservations: Justice Stevens' Factual Approach, 20 Envtl. L. Rep. (Envtl. L. Inst.) 10,429 (Oct. 1990) (lauding Stevens' "new factual approach to Indian law and policy" as one "that better fits the complex facts of Indian reservations than a uniform application of [other] doctrine").

305. See supra Part II.A.4.

306. Stuart Taylor, Jr., The Last Moderate, AM. LAw., June 1990, at 48, 52 . He is reportedly so independent in his approach as to be considered "idiosyncratic." Bernard Schwartz, The UNPUBLISHED OPINIONS OF THE REHNQUIST COURT 12 (1996).

307. In cases where considerations of procedural fairness are involved, such as in the denial of an opportunity to bring historic claims, Stevens favors giving tribes an opportunity to litigate. In Delaware Tribal Business Committee v. Weeks, 430 U.S. 73 (1977); Stevens' dissent expresses concern about the injustice of excluding a portion of a tribe from the payment of a claims award based on apparent drafting errors by Congress. Id. at 91 (Stevens, J., dissenting). An internal memo called the exclusion of the Kansas Delawares "a manifest injustice." Memorandum from Justice John Paul Stevens to Justice William J. Brennan, Jr. (Jan. 6, 1976) (Delaware Tribal Bus. Comm. v. Weeks, Nos. 75-1301, 75-1335, 75-1495), in Brennan Papers, supra note 127. See also Arizona v. San Carlos Apache Tribe, 463 U.S. 545 (1983) (Stevens, J., dissenting) (arguing that the McCarran Amendment does not limit federal court jurisdiction over water rights adjudications); United States $v$. Mitchell, 463 U.S. 206 (1983) (supporting right of Indian tribes to sue United States for breaches of trust in managing forest resources); Arizona v. California, 460 U.S. 605 (1983) (supporting right of Indian tribes to intervene in water rights case); United States v. Sioux Nation of Indians, 448 U.S. 371 (1980) (granting Congress the power to waive the res judicata effect of a prior judicial decision rejecting the validity of a legal claim by the Sioux against the United States). He also dissented from the Court's decision that Congress lacked power to waive state immunity from suit to allow tribal suits challenging a state's lack of good faith in negotiating a compact under the Indian Gaming Regulatory Act, but he treated the issue as essentially a non-Indian law question. See Seminole Tribe of Florida v. Florida, 116 S. Ct. 1114, 1133 (1996).

With the exception of the procedural fairness cases, Stevens' votes in the 71 Indian law decisions since he joined the Court are nearly identical to Chief Justice Rehnquist's. Stevens has disagreed in one case, where he considered Rehnquist (and the majority) to be too generous in recognizing tribal self-government. See California v. Cabazon Band of Mission Indians, 480 U.S. 202,226 (1987). In only three of the non-procedural fairness cases did he take a more generous position toward tribal self-government than Relinquist. See Oklahoma Tax Comm'n v. Chickasaw Nation, 115 S. Ct. 2214 (1995) (joined dissent favoring state income tax exemption for tribal members earning income from the tribe on the reservation); Brendale v. Confederated Tribes \& Bands of Yakima Indian Nation, 492 U.S. 408 (1989) (voting for dividing reservation zoning jurisdiction 
Stevens' apparently benign approach, however, does not portend results that are generally favorable to Indian rights and autonomy. While the goals of equality and fairness may appear to be noble, they can produce perverse results when the rights and prerogatives of Indian tribes that are secured by treaties and legal traditions older than the nation are examined. Freed of their historical inertia, these tribal rights and immunities can appear to be "special" treatment, leading to attempts to reorient them to the dominant society's current notion of fairness as arbitrated by a majority of a particular Supreme Court. As recent subjectivist opinions including Stevens' own amply demonstrate, old Indian rights and tribal self-government itself can be viewed as anomalous or inequitable when viewed without the full benefit of their historical basis.

A major treaty fishing rights decision authored by Stevens, Washington Fishing, ${ }^{308}$ was ostensibly a victory for the tribes. Although it affirmed several tribes' rights to take up to half of the harvestable fish in the streams draining into Washington's Puget Sound, Stevens actually saw his opinion as curbing and modifying the rights announced by the courts below. His goal was to broker among his colleagues a reasonably fair result for both Indians and non-Indians. As the Supreme Court's term was drawing to a close in June 1979, it appeared that the Washington treaty fishing rights case was headed for reargument. Members of a slim majority who had voted to affirm the lower court's allocation of the right to take up to fifty percent of the fish available at their usual and accustomed fishing places began wavering. They were uncomfortable with both the practical implications of Indians taking so many fish and the lack of a legal principle to support a "50-50" allocation of fish. Some proposed that the Court hear reargument that focused on whether the Court should overrule precedent that compelled an allocation of the right to catch fish rather than the right of access to the rivers, with no assurance of the right to catch fish. ${ }^{309}$

between the county and the tribe according to population distribution); Washington $v$. Washington State Commercial Passenger Fishing Vessel Ass'n, 443 U.S. 658 (1979) (Rehnquist dissents from Stevens' approval of an equal sharing of fish between treaty tribes and non-Indians as discriminatory against non-Indians).

308. 443 U.S. 658 (1979).

309. Justice White was troubled by the percentage division and was becoming persuaded by Justice Powell's dissenting opinion, which argued, as the state had urged, that it was enough for the tribes to have a right of equal access to their customary off-reservation fishing places and to be free of state regulation as guaranteed in earlier decisions. White proposed reargument because Justice Powell's position required partially overruling recent Supreme Court caselaw indicating that the treaties also secured the tribes a portion of the fishery and not just a right of access. See Department of Game v. Puyallup Tribe, 414 U.S. 44 (1973). Memorandum from Justice Byron R. White to Justice John Paul Stevens (June 15, 1979) (Washington v. Washington State Commercial Passenger Fishing Vessel Ass'n, Nos. 77-983, 78-119, 78-139), in Marshall Papers, supra note 4. When Chief Justice Burger joined in that proposal, the five-member majority was in doubt. Memorandum from the Chief 
At this point, Stevens broke the impasse. He wrote lengthy internal memoranda to persuade his fellow Justices that the lower court's allocation was essentially fair because it would be more limited in practice than it appeared. Prior to the lower court decision, treaty Indians had only been able to take a small fraction of the fish-not even enough for subsistence. ${ }^{310}$ According to Stevens' calculations, the lower court's ruling would actually provide tribes, even with large numbers of members, with only "between 15 and $20 \%$ " of the fish, not fifty percent." His solution to the possibility that some Indians, especially in small tribes, could use the percentage entitlement to get rich was to impose a further restriction that "'reasonable livelihood needs'-rather than the 50\% ceiling-should provide the primary standard for measuring the Indians' share of the fish." 312 In the third draft of his opinion, he added language to stress that the right of tribes stopped when they reached a "moderate" living standard, an idea not offered by any party or suggested in any of the briefs. He also elaborated on the reduced percentages of the fishery the tribes were likely to take, though the calculations he added to the opinion to garner support had to be modified

Justice to the Conference (June 18, 1979) (Washington v. Washington State Commercial Passenger Fishing Vessel Ass'n, Nos. 77-983, 78-119, 78-139) [hereinafter Burger Washington Fishing Memo to the Conference] (mentioning that he "join[ed] Byron [White] in opting for a re-argument"), in Marshall Papers, supra note 4.

Stevens argued that the Court should not propose reargument on whether to overrule Puyallup II when none of the parties or amici had suggested it. Memorandum from Justice John Paul Stevens to Justice Byron R. White (June 18, 1979) (Washington v. Washington State Commercial Passenger Fishing Vessel Ass'n, Nos. 77-983, 78-119, 78-139) [hereinafter Stevens Washington Fishing Memo to White], in Marshall Papers, supra note 4. Blackmun also weighed in against reargument. Memorandum from Justice Harry A. Blackmun to the Conference (June 19, 1979) (Washington State Commercial Passenger Fishing Vessel Ass'n, Nos. 77-983, 78-119, 78-139), in Marshall Papers, supra note 4. A few days later, after Stevens' compromise proposal described in the next paragraph of text, Burger changed his mind on reargument, laying the matter to rest for laek of support. Memorandum from the Chief Justice to the Conference (June 22, 1979) (Washington State Commercial Passenger Fishing Vessel Ass'n, Nos. 77-983, 78-119, 78-139), in Marshall Papers, supra note 4.

310. Stevens was concerned that mere access to the fishery-the solution urged by the state and accepted by Powell's dissent-would not meet the needs of the tribe. "[T]he Indians were catching only about 2 to $31 / 2 \%$ of the [fish in] the runs whereas the District Court found that their subsistence and ceremonial needs in later years required about 5\%." Stevens Washington Fishing Memo to White, supra note 309 , at 1-2 (citations omitted).

311. See Memorandum from Justice John Paul Stevens to Justice Potter Stewart (June 1, 1979) (Washington v. Washington State Commercial Passenger Fishing Vessel Ass'n, Nos. 77-983, 78-119, and 78-139), in Marshall Papers, supra note 4. The calculation was based in part on Stevens' speculation that the tribes were substantially certain not to prevail on their claim to a right to take a share of hatchery-bred fish, as opposed to native stocks, thus reducing the fish available to them from some runs by about half. Id. In fact, the tribes eventually won confirmation of their right to take a share of hatchery-propagated fish. United States v. Washington, 759 F.2d 1353, 1360 (9th Cir. 1985).

312. Memorandum from Justice John Paul Stevens to the Conference (June 18, 1979) Washington v. Washington State Commercial Passenger Fishing Vessel Ass'n, Nos. 77-983, 78-119, 78-139) [hereinafter Stevens Washington Fishing Memo to the Conference], in Marshall Papers, supra note 4. 
on a motion by the state which pointed out there was no evidence on the record to support the figures. ${ }^{313}$ Stevens' qualifcation, which Chief Justice Burger characterized Stevens' approach as "an 'arbitration' holding," enabled him to secure a majority vote. ${ }^{314}$

Justice Stevens' lack of concern with tying decisions to established principle is illustrated by Brendale, in which he states that reservation zoning jurisdiction should depend on the degree of non-Indian presence in particular areas. ${ }^{315}$ His 1994 opinion in Milhelm exemplified his continuing commitment to the subjectivist course. ${ }^{316}$ Without dissent, Stevens relied explicitly on interest balancing to extend state jurisdiction over reservation Indians, a first for the Supreme Court. When Justice Stevens is assigned opinions in Indian jurisdiction cases, he can be expected to further the subjectivist approach and to draw the less-experienced and less-interested members of the Court to his positions.

\section{Justice O'Connor}

Justice O'Connor remains somewhat independent on Indian issues, as is true of her position in other fields. ${ }^{317}$ Her decision in Rice $v$. Rehner ${ }^{318}$ suggests that she is not dedicated to foundation principles. Indeed, Rice is the lone example of a inajority opinion that expressly accepts Rehnquist's idiosyncratic version of a "tradition of sovereignty." 319 Six Justices joined in holding that California could impose its liquor licensing laws on a federally licensed Indian trader operating a store on the reservation. O'Connor began:

313. The Court granted the State's motion for modification of the opinion by changing footnote 16, which had been added by Stevens in the last days of the term to draw a majority vote. Washington v. United States, 444 U.S. 816 (1979). An explanation concerning how, at most, "the Indians' take would only amount to about 20\%," see Stevens Washington Fishing Memo to the Conference, supra note 312 , was removed because it was not supported by the record. The footnote now says only that a "factual dispute exists on the question of what percentage of the fish" are subject to the Court's allocation on which the Supreme Court is "unable to express any view." Washington Fishing, 443 U.S. at 671 n.16.

314. Burger Washington Fishing Memo to the Conference, supra note 309.

315. Brendale v. Confederated Tribes \& Bands of Yakima lndian Nation, 492 U.S. 408, 433-48 (1989); see supra Part 11.A.4.

316. See Department of Taxation \& Fin. v. Milhelm Attea \& Bros., 114 S. Ct. 2028 (1994); supra notes 265-275 and accompanying text.

317. See Erwin Chemerinsky, Is The Rehnquist Court Really That Conservative?: An Analysis of the 1991-92 Term, 26 Creighton L. Rev. 987, 987 (1993); Charles Jordan Tabb, The Bankruptcy Reform Act in the Supreme Court, 49 U. PrrT. L. Rev. 477, 482 (1988) (noting "the growing independence of Justice $O^{\prime}$ Connor from the conservative bloc of the Court").

318. 463 U.S. 713 (1983). One scholar writes that in Rice Justice O'Connor "severed the Court's ties to the canon of inherent tribal sovereignty." Karl J. Kramer, Comment, The Most Dangerous Branch: An Institutional Approach to Understanding the Role of the Judiciary in American Indian Jurisdictional Determinations, 1986 W1S. L. REv. 989, 1028.

319. See supra notes 139-143, 288-292 and accompanying text (discussing Rehnquist's preemption approach). 
We first determine the nature of the "backdrop" of tribal sovereignty that will inform our pre-emption analysis. The "backdrop" in this case concerns the licensing and distribution of alcoholic beverages, and we must determine whether there is a tradition of tribal sovereign immunity that may be repealed only by an explicit directive from Congress. ${ }^{320}$

She found that tribes historically had not engaged in liquor regulation and therefore concluded that "there is no tradition of sovereign immunity that favors the Indians in this respect." 321 Justice Blackmun, in a dissent joined by Justices Brennan and Marshall, interpreted the federal liquor law as clearly preempting the liquor laws of California from applying directly to the Indian trader. Blackmun characterized O'Connor's opinion as "argu[ing] to a result that it strongly feels is desirable and good. But that, however strong the feelings may be, is activism in which this Court should not indulge." ${ }^{\text {"322 }}$

O'Connor also wrote an opinion, which was never issued, that would have altered established Supreme Court Indian water rights doctrine and potentially undermined many tribal claims to water rights on reservations. An eighty-year-old decision had held that water rights were impliedly reserved whenever an Indian reservation was set up, in order to provide for future needs of the tribes. ${ }^{323}$ Accordingly, the Wyoming Supreme Court awarded the tribes of the Wind River Reservation reserved water rights for projected future demands for irrigating the "practicably irrigable acreage on the reservation,"324 a formula approved by the United States Supreme Court in the famous Arizona $v$. California litigation. ${ }^{325}$ The Wyoming decree included acreage to be irrigated by future water projects whose engineering and economic feasibility had been demonstrated. ${ }^{326}$ O'Connor disapproved of this approach. Her draft opinion in Wyoming $v$. United States rejected the Indians' rights to water for future projects, saying that greater "pragmatism" was required out of "[s]ensitivity to the impact on [non-

320. Rice, 463 U.S. at 720 (emphasis added).

321. Id. at 725. O'Connor did not rely entirely on Rehnquist's history-based tradition of sovereignty. She also considered the relative interests of the tribe and the State in regulating liquor that were implicitly recognized by statute. Id. at 723-24. However, Congress did so in the context of delegating to tribes the authority to lift a blanket prohibition on liquor sales on their reservations. Yet she surmises that preemption of state law could not apply so long as a liquor transaction is "in conformity both with the laws of the State ... and with an ordinance duly adopted by the tribe having jurisdiction over such area of lndian country." Id. at 716 (quoting 18 U.S.C. $\$ 1161$ ) (internal quotations omitted).

322. Id. at 744.

323. Winters v. United States, 207 U.S. 564, 577 (1908).

324. In re Rights to Use Water in the Big Horn River Sys., 753 P.2d 76, 101 (Wyo. 1988), aff'd sub nom. Wyoming v. United States, 492 U.S. 406 (1989).

325. 373 U.S. 546 (1963).

326. See Big Horn River Sys., 753 P.2d at 101-02. 
Indian] prior appropriators."327 A majority of the Court subscribed to the opinion, reversing the lower court and curtailing the quantity of water rights reserved to the Wind River Indian Reservation. O'Connor, however, suddenly recused herself from the case the day before the opinion was to be released, leaving the eight remaining members of the Court equally divided. Consequently, the decision is simply reported as an affirmance of the State court without opinion. ${ }^{328}$

Justice O'Connor's majority opinion in Hagen v. Utah plumbed nineteenth-century policies of allotment and assimilation to find that arguably ambiguous statutes had terminated tribal jurisdiction over a reservation in Utah. ${ }^{329}$ Yet only a year before, she had written for a unanimous court in the Sac \& Fox case that Indian country in Oklahoma extended not only to reservation lands but also to allotments

327. Second Draft Opinion of Justice Sandra Day O'Connor, Wyoming v. United States, No. 88309, at 17 (June 12, 1989) [hereinafter Second Draft Wyoming Opinion], in Marshall Papers, supra note 4. Justice White circulated a concurring opinion stressing the inequity of allowing the tribes extensive rights that they may never need to develop and gratuitously commented that "specific attributes of [reserved rights] have never been authoritatively decided," such as whether the rights might be subject to forfeiture if not used for their adjudicated purpose within a certain time or whether they might be sold or leased for use on or off the reservation. First Draft Concurrence of Justice Byron White, Wyoming v. United States, No. 88-309, at 2 (June 13, 1989), in Marshall Papers, supra note 4.

328. The decision was scheduled to be announced on June 23, 1989. See Memorandum from the Chief Justice to the Conference (June 15, 1989) (Wyoming v. United States, No. 88-309), in Marshall Papers, supra note 4. Justice Brennan completed a lengthy dissenting opinion in which Marshall and Blackmun joined. See First Draft Dissent of Justice William J. Brennan, Jr., Wyoming v. United States, No. 88-309 (June 16, 1989) [hereinafter First Draft Wyoming Dissent], in Marshall Papers, supra note 4; Memorandum from Justice Thurgood Marshall to Justice William J. Brennan, Jr. (June 20, 1989) (Wyoming v. United States, No. 88-309), in Marshall Papers, supra note 4; Memorandum from Justice Harry A. Blackmun to Justice William J. Brennan, Jr. (June 22, 1989) (Wyoming v. United States, No. 88-309), in Marshall Papers, supra note 4. The dissent argued that the "defect" found by the majority in the practicably irrigable acreage standard was really a concern that too few Indians would get too much water. "The Court's 'sensitivity' to the interests of one group appears to be matched by a suspicion that the other is getting more than it deserves." First Draft Wyoming Dissent, supra, at 13. Brennan contended that "'[s]ensitivity' to the interest of one of the two groups is an illegitimate thumb on the scales," and then reviewed the evidence to show that the Court's "factual assumption" that the lower court's application of the standard "provides the Tribes with more water than they need is ... outrageously wrong." Id. Stevens circulated a one paragraph dissent noting that the Wyoming Supreme Court did not address whether future irrigation projects would be built, inferring that Wyoming had not pressed the issue below, and thus maintained that the matter should not be remanded. First Draft Dissent of Justice John Paul Stevens, Wyoming v. United States, No. 88-309 (June 22, 1989), in Marshall Papers, supra note 4. This made the vote 5-4.

O'Connor then circulated a memorandum on June 22 stating that she believed she should disqualify herself from the case because her family's ranching corporation "ha[d] been named in a river water suit brought by an Indian tribe affecting the Gila River [in Arizona], which adjoins a portion of the ranch." Memorandum from Justice Sandra Day O'Connor to the Conference (June 22, 1989) (Wyoming v. United States, No. 88-309), in Marshall Papers, supra note 4.

329. See Hagen v. Utah, 510 U.S. 399, 414-17 (1994). For a discussion of the case, see supra notes 216-222 and accompanying text. For a discussion of nineteenth-century allotment policy, see supra notes 223-25land accompanying text. 
outside reservations. ${ }^{330}$ The latter case reads like a traditional Indian law decision and applies the preemption analysis of McClanahan and White Mountain. O'Connor, like most members of the Court, proves herself capable of employing foundation principles to justify an outcome that fits her views of what ought to be; however, she does not hesitate to invoke a subjectivist approach and disregard foundation principles if necessary to produce a desired result contradicting those principles.

Justice O'Connor's willingness to measure the rights of Indian tribes with special sensitivity to the values and equities of non-Indian society indicates that she, like Rehnquist and Stevens, belongs in the subjectivist camp in Indian cases. For example, although O'Connor based her decision in Rice on the lack of a tradition of tribal immunity from state licensing and distribution of liquor, the strength of California's interest in regulating liquor was also a key factor for her. ${ }^{331}$ Furthermore, her draft opinion in Wyoming revealed a desire to redefine Indian rights according to the equities of non-Indians rather than adhering to precedent and principle. ${ }^{332}$ She was willing to embrace foundation principles in Sac \& Fox, but, as Hagen proves, only if these principles would not disturb a result subjectively reached.

\section{Justice Scalia}

Justice Scalia has candidly summarized his view of the Supreme Court's approach to Indian law as a search for "what the current state of affairs ought to be." ${ }^{333}$ The license for judicial policy-making that Scalia infers and accepts would seem more historically valid if one looked only as far as cases that were decided during Scalia's brief time on the Court prior to Duro, such as Brendale and Cotton Petroleum. ${ }^{334}$

330. See Oklahoma Tax Comm'n v. Sac \& Fox Nation, 508 U.S. 114, 123 (1993).

331. See Rice v. Rehner, 463 U.S. 713, 724 (1983); supra note 321.

332. See Second Draft Wyoming Opinion, supra note 327.

333. Scalia Duro Memo, supra note 4 (emphasis added).

334. In his nearly three terms on the Court prior to Duro, Scalia had voted with the majority in seven of eight Indian cases decided by the Court. See Brendale v. Confederated Tribes \& Bands of Yakima Indian Nation, 492 U.S. 408 (1989) (joining Justice White's plurality on the "open" portion of the reservation and dissenting on the "closed" portion); Mississippi Band of Choctaw Indians v. Holyfield, 490 U.S. 30 (1989); Cotton Petroleum Corp. v. New Mexico, 490 U.S. 163 (1989); Oklahoma Tax Comm'n v. Graham, 489 U.S. 838 (1989); Lyng v. Northwest Indian Cemetery Protective Ass'n, 485 U.S. 439 (1988); Montana v. Crow Tribe of Indians, 484 U.S. I039 (1988); Iowa Mut. Ins. Co. v. LaPlante, 480 U.S. 9 (1987). When Duro came up, Scalia had just written his first Indian law opinion, Employment Div., Dep't of Human Resources v. Smith, 494 U.S. 872 (1990), which was essentially a First Amendment decision in the context of the Indian peyote religion. The decision drew widespread negative commentary for abandoning the compelling interest test for free exercise of religion cases. See Robert N. Anderson, Just Say No to Judicial Review: The Impact of Oregon v. Smith on the Free Exercise Clause, 76 IowA L. REv. 805, 815-23 (1991); Thomas F. LaMacchia, Note, Reverse Accommodation of Religion, 81 GEO. L.J. 117, $123-26$ (1992); Kristie Pospisil, Note, Employment Division, Department of Human Resources v. Smith: What Remains of Religious Accommodation Under the Free Exercise Clause?, 52 LA. L. REv. 231, 249 (I99I). In 
That does not excuse, however, his failure to search more deeply for the enduring foundation principles of Indian law.

The admission by Scalia also seems inconsistent with his purported judicial philosophy. The straightforward quote stands in sharp contrast with his professed view, expressed in an interview the same year, that " a judge's task is 'not to determine what seems like good policy at the present time, but to ascertain the meaning of the text." "'335 Categorizations of Scalia as a textualist or a traditionalist are, indeed, doubtful. Some scholars have speculated that for Scalia, holding true to a particular method is not as important as his substantive agenda. ${ }^{336}$ Others say that he considers methods subordinate to an overall judicial philosophy that favors enunciation of clear rules. ${ }^{337}$ In Indian law, however, Scalia appears to have no "agenda" and he seems content to allow cases to be decided on what ought to be today's policy.

Justice Scalia demonstrated this tendency in his only Indian jurisdiction majority opinion since joining the Court. In County of Yakima v. Confederated Tribes \& Bands of the Yakima Indian Nation, ${ }^{338}$ he drew extended inferences from scant legislative history to interpret a statute, which was silent on taxation, as allowing state taxation of Indian-owned allotments within a reservation. ${ }^{339}$ The decision rested largely on suppositions about nineteenth-century congressional intent. ${ }^{340}$ In another case that confronted directly the nature of tribal sovereignty, Scalia ignored foundation principles and the text of the Eleventh Amendment to hold that states are immune from suit by tribes. ${ }^{341}$ Notwithstanding his pro-

1993, Congress reversed the rationale, restoring the compelling interest test by statute. See Religious Freedom Restoration Act of 1993, 42 U.S.C. $\$ 2000 \mathrm{bb}$ (1994).

335. George Kannar, The Constitutional Catechism of Antonin Scalia, 99 YALE L.J. 1297, 1303 (1990) (quoting Scalia), quoted in Michael J. Gerhardt, A Tale of Two Textualists: A Critical Comparison of Justices Black and Scalia, 74 B.U. L. REv. 25, 30 (1994). One commentator argues that Scalia's "attacks on judicial activism and subjectivism" are essentially disingenuous because he is constantly making choices among interpretations, rules, and definitions that turn his decisions into subjective exercises. Bradley C. Karkkainen, "Plain Meaning": Justice Scalia's Jurisprudence of Strict Statutory Construction, 17 HARV. J.L. \& PUB. POL'y 401, 476 (1994).

336. See, e.g., David A. Strauss, Tradition, Precedent, and Justice Scalia, 12 Cardozo L. Rev. 1699, 1700-01 (1991).

337. See, e.g., Karkkainen, supra note 335, at 476; Eric J. Segall, Justice Scalia, Critical Legal Studies, and the Rule of Law, 62 GEO. WASH. L. REv. 991, 1034-35 (1994).

338. 502 U.S. 251 (1992).

339. See id at 258-64.

340. See id. at 253-56.

341. See Blatchford v. Native Village of Noatak, 501 U.S. 775 (1991). The Eleventh Amendment expressly immunizes states from suits "by Citizens of another State, or by Citizens or Subjects of any Foreign State." U.S. CONST. amend XI. In two previous situations (involving nonforeign sovereigns) the Court has limited state immunity where suit is not explicitly barred by the text. See United States v. Mississippi, 380 U.S. 128, 136-38 (1965) (states subject to suits by the United States); North Dakota v. Minnesota, 263 U.S. 365, 372-74 (1923) (states subject to suits by sister states). In two other cases (involving foreign states and private individuals) the Court has extended state immunity beyond the words of the Amendment. See Principality of Monaco v. Mississippi, 292 
claimed distaste for judical policy making, Scalia appears content to join the subjectivist camp when it comes to issues of Indian law.

\section{Justice Kennedy}

Justice Anthony Kennedy is a probable ally of Justices Rehnquist, Stevens, O'Connor, and Scalia in Indian jurisdiction and sovereignty cases. This generalization is supported by his single, but significant, Indian sovereignty opinion. In Duro v. Reina, ${ }^{342}$ the Court cited insubstantial authority for denying the tribal court's jurisdiction over crimes committed by non-member Indians on a reservation. ${ }^{343}$ Kennedy's opinion worried about the fate of outsiders in a tribal court system, given "the special nature of the [Indian] tribunals" with their "unique customs, languages, and usages." 344 The holding left a serious law enforcement gap on many reservations, a problem so significant that Duro was quickly reversed by an act of Congress. ${ }^{345}$

Since taking his seat on the Court in 1988, Kennedy has always voted with Chief Justice Rehnquist in Indian jurisdiction cases and has invariably joined every opinion that denied tribal sovereignty. This includes Justice White's opinion in Brendale, which would have denied tribal zoning jurisdiction anywhere on the Yakima Reservation. ${ }^{346}$ Kennedy's departures from Scalia, especially in First Amendment cases, have led some commentators to perceive a streak of independence and moderation. ${ }^{347}$ They cite his opinions affirming the right of Krishnas to

U.S. 313,330 (1934) (states immune from suits by foreign states as well as their citizens without the state's consent); Hans v. Louisiana, 134 U.S. 1, 4-6 (1890) (states immune from suits in federal courts by its own citizenry on a federal question). Scalia relied on the "presupposition of our constitutional structure" reflected in the Amendment to find an implied immunity of states from suits by tribes. Blatchford, 501 U.S. at 779; see also Seminole Tribe v. Florida, 116 S. Ct. 1114 (1996) (holding that Congress lacks constitutional power under the Commerce Clause to override state immunity from suit by an Indian tribe). In Blatchford, Scalia apparently assumed that tribal governments, in their relations with states, would be regarded by the Framers as being equivalent to individual citizens or foreign nations rather than treating them as domestic sovereigns such as states or the federal government. See 501 U.S. at 779-82. Compare this reasoning with Chief Justice Marshall's decision and rationale in Cherokee Nation v. Georgia, 30 U.S. (5 Pet.) 1 (1831) (tribes are domestic dependent nations, not foreign states).

342. 495 U.S. 676 (1990).

343. See id. at 684-92.

344. Id. at 693 .

345. See Act of Nov. 5, 1990, Pub. L. No. 101-511, § 8077(b) (amending Indian Civil Rights Act, 25 U.S.C. $\$ 1301(2))$.

346. See Brendale v. Confederated Tribes \& Bands of Yakima Indian Nation, 492 U.S. 408 (1989) (plurality opinion). Kennedy also joined, along with Rehnquist, in Stevens' dissent in Mississippi Band of Choctaw Indians v. Holyfield, 490 U.S. 30, 54 (1989), favoring a narrow interpretation of tribal jurisdiction under the Indian Child Welfare Act.

347. See Lawrence Friedman, The Limitations of Labeling: Justice Anthony M. Kennedy and the First Amendment, 20 OHIo N.U. L. REv. 225, 226 (1993); Christopher E. Smith, Supreme Court Surprise: Justice Anthony Kennedy's Move Toward Moderation, 45 OKLA. L. REv. 459, 460 (1992); Richard C. Reuben, Man in the Middle, CAL. LAw., Oct. 1992, at 34. 
distribute materials in airports and prohibiting prayer in schools. ${ }^{348}$ Despite this purported independence in First Amendment cases, Kennedy voted with Scalia to conclude that disfavoring a minority Indian religion (peyotism) was an "unavoidable consequence" of our system of democratic government. ${ }^{349}$ Kennedy certainly will not motivate the Court to return to foundation principles. He has displayed a profound disinterest in Indian law and should be counted as likely to vote with the other subjectivist Justices.

\section{Justice Souter}

In a relatively short tenure, spanning ten Indian law cases, Justice Souter has demonstrated some tendency to adhere to foundation principles of Indian law. He was the only member of the Court to join strong Blackmun dissents from the subjectivist approaches of the Court in Hagen and Bourland, and he joined Justice Breyer's dissent in Chickasaw. ${ }^{350}$ Yet he was content to be part of the majority in Yakima, where the Court breathed life into the Allotment Act and allowed state taxation of reservation lands owned by Indians, ${ }^{351}$ and the unanimous decision in Milhelm, which extended state regulation over tribal tobacco trading. ${ }^{352}$ Nevertheless, he has not yet written an opinion of his own in an Indian case $^{353}$ and had no experience in Indian cases as a state supreme court justice. It may be too early to generalize about Souter, but his diligence and intellect may yet incline him to lead the Court in future cases.

\section{Justice Thomas}

Justice Thomas decided no Indian cases in his brief, eighteenmonth judicial career prior to being appointed to the Supreme Court. In his lengthy and celebrated confirmation hearings, he was not asked

348. See Friedman, supra note 347, at 259 (citing International Soc'y for Krishna Consciousness v. Lee, 505 U.S. 672 (1992); Lee v. Weisman, 505 U.S. 577 (1992)). But cf. Rosenberger v. Rector \& Visitors of Univ. of Va., 115 S. Ct. 2510 (1995) (majority opinion by Kennedy holding that state university funding of Christian magazine did not constitute establishment of religion in violation of First Amendment).

349. Employment Div., Dep't of Human Resources v. Smith, 494 U.S. 872, 890 (1990).

350. Oklahoma Tax Comm'n v. Chickasaw Nation, 115 S. Ct. 2214, 2225 (1995) (Breyer, J., concurring in part and dissenting in part).

351. County of Yakima v. Confederated Tribes \& Bands of Yakima Indian Nation, 502 U.S. 251 (1992).

352. Department of Taxation \& Fin. v. Milhelm Attea \& Bros., 114 S. Ct. 2028 (1994); cf. Blatchford v. Native Village of Noatak, 501 U.S. 775, 779-82 (1991) (relying on sovereign immunity of states to deny tribes the right to sue a state without that state's consent).

353. Souter did write a dissent in Seminole Tribe v. Florida, 116 S. Ct. 1114, 1145 (1996). It was a lengthy, scholarly study of the constitutional power of Congress, arguing that a statute allowing a tribe to sue a state should be upheld. Traditional Indian law principles were not involved, but Souter included a strong explanation of the foundations of state sovereignty. Id. at 1169-73. 
any questions about Indian law. ${ }^{354}$ Justice Thomas is depicted by some commentators as perhaps "one of the most conservative justices of the late-twentieth century" ${ }^{355}$ and, more harshly, as a heartless, knee-jerk conservative. ${ }^{356}$ But political classifications are unhelpful; indeed, keeping faith with foundation principles in Indian law is essentially conservative. Dean Soifer has criticized Thomas for his only Indian-related Supreme Court opinion, South Dakota v. Bourland, ${ }^{357}$ alleging that it is hypocritical to profess conservative principles and then find tribal sovereignty over hunting and fishing regulation to be abrogated implicitly by an act of Congress silent on the subject. ${ }^{358}$ Bourland denied the Cheyenne River Sioux Tribe jurisdiction over lands within the reservation based on a construction of the Flood Control Act of 1944 , a statute authorizing the taking of lands within the reservation for a federal reservoir. ${ }^{359}$ Thomas' opinion presumed that Congress' failure to reserve explicitly more of the tribe's aboriginal sovereignty when taking the lands "suggests that the Indians would otherwise be treated like the public at large."360 Furthermore, in a footnote offering an expansive interpretation of Montana, Thomas blatantly announced that "tribal sovereignty over non-members 'cannot survive without express congressional delegation' ... and is therefore not inherent."

Thomas should be included among the subjectivists. One need not rely on popular generalizations that simply presume he will always vote with Justice Scalia. ${ }^{362}$ His positions in Bourland and the other five Indian cases decided since he joined the Court are evidence of his subjectivism.

354. John E. Thorson, Proceedings of the Symposium on Settlement of Indian Water Rights Claims, 22 ENvTL. L. 1009, 1012 (1992).

355. Julian Abele Cook, Jr., Thurgood Marshall and Clarence Thontas: A Glance at Their Philosophies, 73 MrcH. B.J. 298, 302 (1994) (citing Jeffrey Toobin, The Burden of Clarence Thomas, NeW YORKer, Sept. 27, 1993, at 41).

356. Catharine Pierce Wells, Clarence Thomas: The Invisible Man, 67 S. CAL. L. Rev. 117, 14546 (1993).

357. 508 U.S. 679 (1993).

358. Aviam Soifer, Objects in Mirror Are Closer Than They Appear, 28 GA. L. REv. 533, 535 (1994). Dean Soifer takes both Scalia and Thomas to task for insisting "that there must be strict judicial fidelity to legal texts. Yet when we turn to majority opinions written by Scalia and Thomas respectively, we will see that these judges simply wave away directly relevant texts and language, claiming that they must do so in the service of history." Id.

359. See Bourland, 508 U.S. at 689-90.

360. Id. at 693-94.

361. Id. at 695 n.15 (citing Montana v. United States, 450 U.S. 544,564 (1981)).

362. Judge Cook points out that Thomas has voted with Scalia in 79 to $89 \%$ of the cases during his first two years on the court. Cook, supra note 355, at 298. Dean Soifer refers to Thomas as Scalia's "acolyte." Soifer, supra note 358, at 535. 


\section{Justice Ginsburg}

Justice Ginsburg has been on the Supreme Court for only three decisions involving Indian jurisdictional issues: Milhelm, Hagen, and Chickasaw. She joined the unanimous court in Milhelm, and in Hagen sided with the majority in a case where only Justices Souter and Blackmun dissented. Chickasaw is her only Supreme Court opinion on Indian sovereignty. It properly held that the Chickasaw tribe was not subject to a state tax on motor fuels sold at tribal stores and, on a closer issue, rejected a claim of immunity from state income tax by a tribal member employed by the tribe on the reservation but living off the reservation. ${ }^{363}$ Though both results could be based on established principles, the Chickasaw opinion inaccurately restated applicable rules and never discussed preemption. Besides showing some technical confusion about the meaning and applicability of the term "legal incidence" in taxation cases, ${ }^{364}$ she incorrectly stated dicta to the effect that state regulation cases not involving taxation, and taxation cases involving nonIndians, are to be decided by a balancing test. ${ }^{365}$ As the final subsection in the preceding Part of this Article argues, it is incorrect to see preemption analysis as a "balancing inquiry," though it may be understandable that one would draw the conclusion from a cursory reading of recent cases.

The second issue before the Court iu Chickasaw was whether the state could tax income earned by Indians living off the reservation from tribal employment on the reservation, a matter of first impression. In deciding this issue, Justice Ginsburg conspicuously avoided the wellestablished preemption analysis of McClanahan. ${ }^{366}$ The Court might have decided that state taxes under such circumstances are generally preempted. Alternatively, the Court could have based a decision more

363. See Okla. Tax Comm'n v. Chickasaw Nation, 115 S. Ct. 2214 (1995).

364. In Chickasaw, the fuel tax issue was resolved by stating the well-established rule barring taxation of Indians and Indian tribes within Indian country. Justice Ginsburg added, however, that the tax here was barred because "its legal incidence falls on a Tribe." Id. at 2217 . While reaching the correct result, the opinion stated a rationale that is actually the converse of a rule applicable to taxation of non-Indians within an Indian reservation. The rule is that states may impose taxes in Indian country where the legal incidence falls on non-Indians; if the tax impacts tribal government or federal policies, the tax is to be preempted. See, e.g., Ramah Navajo Sch. Bd., Inc. v. Bureau of Revenue, 458 U.S. 832, 837-38 (1982); White Mountain Apache Tribe v. Bracker, 448 U.S. 136, 144-45 (1980). The Chickasaw Court had to determine only that the tax was imposed on the tribe. Technically the "legal incidence" cannot fall on any entity that is immune from taxation (such as a tribe or Indians within Indian country). In other cases, the Court has said that the "legal incidence" of a tax is on the first activity "which may constitutionally be subjected to it." Colville, 447 U.S. at 142 n.9; see also California State Bd. of Equalization v. Chemehuevi Indian Tribe, 474 U.S. 9, 11 (1985). Thus, it makes no sense to speak of the Iegal incidence being on the tribe since the tribe is immune.

365. See Chickasaw, 115 S. Ct. at 2220.

366. See id. at 2222-24. 
narrowly on the language of the Chickasaw treaty, which arguably was sufficiently protective of the tribe's immunity from state jurisdiction to be preemptive. If not, it should have based any decision denying tax immunity on an analysis concluding the laws in question did not support it. But to uphold or deny the imposition of the tax would seem to require the preemption analysis routinely used by the Court in the modern era, especially in tax cases. ${ }^{367}$ Instead, Ginsburg simply rejected the claimed tax immunity because the Indian employee lived off the reservation. She sought a bright-line test to separate taxability from nontaxability. This is not the same subjectivism indulged by her fellow Justices, but neither is it consistent with well-established Indian law jurisprudence. Implied preemption is not as vague and malleable as a subjective evaluation of each case to determine what the current state of affairs ought to be, but neither is it as simple as a bright-line rule.

Despite her opinion in Chickasaw, Justice Ginsburg may be capable of leading the Court back to basic principles. While Ginsburg wrote no opinions on Indian law in her eleven years as a District of Columbia Circuit Court judge, she joined in one opinion that reflected a strong understanding of the nature and importance of tribal sovereignty. ${ }^{368}$ During her confirmation hearings she was grilled repeatedly by Senator Pressler of South Dakota about her views on Indian law. She consistently responded by saying that she would do her best to apply the policies set by Congress with respect to tribal governance. ${ }^{369}$ She also stated, "The courts do not have any law creation role to play. This is not a common law area. This is an area for Congress to control." 370 Perhaps Ginsburg will rediscover the foundation principles that have guided Indian law in the past.

\section{Justice Breyer}

Justice Breyer, the newest member of the Court, encountered a few Indian cases in his tenure on the First Circuit Court of Appeals. For

367. See, e.g., Ramah, 458 U.S. at 836-47; Central Machinery Co. v. Arizona State Tax Comm'n, 448 U.S. 160, 165-66 (1980); White Mountain, 448 U.S. at 141-52; McClanahan v. Arizona State Tax Comm'n, 411 U.S. 164, 173-81 (1973).

368. See Muscogee (Creek) Nation v. Hodel, 851 F.2d 1439, 1440 (D.C. Cir. 1988) (reversing Bureau of Indian Affairs' denial of funds for a tribal court and law enforcement program). The Muscogee decision stated that "[i]nherent in self-government is the power to make laws and to create mechanisms to enforce them. It is therefore reasonable to conclude that [federal law] conferred all powers associated with self-government, limited of course by statutes of general applicability." Jd. at 1445 (citation omitted). One Ginsburg lower court opinion discusses an Indian case in the course of considering and denying a claim to the religious use of marijuana. Olsen v. DEA, 878 F.2d 1458, 1464-65 (D.C. Cir. 1989) (distinguishing exemption for peyote use by the Native American Church).

369. See Confirmation of Ruth Bader Ginsburg as Supreme Court Justice: Hearing of the Senate Comm. on the Judiciary, 103d Cong., 1st Sess. (1993).

370. Id. 
twenty years, that court has faced a series of land claims by vestigial groups of Indians in New England challenging titles to land going back some 200 years. ${ }^{371}$ Conveyances made to states or private individuals by Indians are subject to the requirement of United States government approval under the Indian Nonintercourse Act, which emanated from the first Congress. ${ }^{372}$ Tribes have sought to void present titles by showing that the Indian title to the same lands was extinguished in violation of the Act.

The Mashpee Tribe has pursued such a claim for many years. In one First Circuit opinion, the court applied an early Supreme Court case and affirmed a jury verdict that found the Mashpees did not fulfill the criteria needed for tribal existence. ${ }^{373}$ Because of the obvious problem of a modern, non-Indian jury being entrusted with a fundamental cultural decision about historical tribal existence, there was considerable scholarly criticism of the decision. ${ }^{374}$ Breyer did not sit on that case, but he participated in related decisions and wrote a 1987 opinion involving the Mashpees as well as other groups. ${ }^{375}$ The claim to tribal status in the latter case was based on documents from which one might infer that the federal government historically treated the Mashpees and other groups claiming land as tribes. ${ }^{376}$ Breyer, however, found the reports mentioning the Indians to be unavailing in proving tribal status through government recognition. ${ }^{377}$ He thus affirmed the trial court's view of the evidence. $^{378}$

More revealing of Breyer's approach to Indian cases may be an earlier decision in which he denied Indian claims to land on the Gay Head Peninsula. ${ }^{379}$ The Indians sought to invalidate Massachusetts statutes that permitted certain conveyances of Indian land. Breyer correctly stated that because the Indian Nonintercourse Act by its terms applied only to conveyances by tribes, individual land claims could not be brought under it. But his opinion also inferred that, but for the Act, Indian land title would be subject to state law. ${ }^{380}$ Later cases proved

371. The first such case was Joint Tribal Council of Passamaquoddy Tribe v. Morton, 528 F.2d 370 (1st Cir. 1975).

372. See 25 U.S.C. $\$ 177$ (1994). This is a substantial reenactment of legislation dating to 1790,1 Stat. 137.

373. See Mashpee Tribe v. New Seabury Corp., 592 F.2d 575, 587-88 (1st Cir. 1979) (relying on, but refusing to adopt, the criteria of Montoya v. United States, 180 U.S. 261, 266 (1901)).

374. See, e.g., Martha Minow, Making All The Difference 355 (1990); Gerald Torres \& Kathryn Milun, Translating Yonnondio by Precedent and Evidence: The Mashpee Indian Case, 1990 Duke L.J. 625, 629.

375. See Mashpee Tribe v. Secretary of the Interior, 820 F.2d 480 (1st Cir. 1987).

376. See id. at 483.

377. See id. at 483-84.

378. See id. at 485.

379. See James v. Watt, 716 F.2d 71 (1st Cir. 1983).

380. See id. at 76 . 
much of Breyer's analysis on this point to be wrong. ${ }^{381}$ In fact, the Act merely implemented the principle of inalienability of Indian land without participation by the sovereign, a principle that can be traced to the colonial relationship with the Indians. That principle was embodied in the Commerce Clause, describing the constitutional relationship among the nation, the tribes, and the states, and granting Congress authority over Indian affairs to the exclusion of the states. ${ }^{382}$ While state law has operated in some situations in Indian country where Indians are not affected, control of Indian land title has never been a state prerogative.

Breyer compounded his error in the Gay Head case by overstating the nature of state legislative power in Indian affairs. He concluded that the Massachusetts laws allowing transfer of Indian lands should be evaluated by an "interest balancing" approach to preemption, which he attributed to cases like McClanahan, White Mountain, and Mescalero. ${ }^{383}$ The case of the Gay Head Indians was Breyer's first opinion in the field, and one of only three he wrote as a court of appeals judge. ${ }^{384}$ Troubling as it may be for its flaws, the opinion was written more than a decade before his appointment to the Supreme Court and may not reflect how he will deal with Indian cases in the future.

In his confirmation hearings Breyer was questioned by Senator Pressler about his knowledge and views on Indian law. ${ }^{385}$ While carefully avoiding the Senator's attempts to engage him in discussions of cases likely to come before the Court, he was conversant with key principles, some traceable to courses he taught at Harvard Law School, and some doubtless the result of good preparation. He talked about the history and meaning of Worcester. ${ }^{386}$ He also opined on the authority of

381. See County of Oneida v. Oneida Indian Nation, 470 U.S. 226, 234-38 (1985) (with adoption of Constitution, Indian land transactions became the exclusive right of the Unitcd States government). Under the Articles of Confederation, a different policy was in place; only during that period did the national government lack the exclusive right to extinguish Indian title. See Oneida Indian Nation v. New York, 860 F.2d 1145, I154 (2d Cir. 1988).

382. See U.S. CoNST. art. I, \& 8, cl. 3.

383. See Watt, 716 F.2d at 73-74. Breyer wrote, "Supreme Court decisions since Chief Justice Marshall's time have generally rejected the concept that the Clause automatically and necessarily preempts all state laws dealing with Indians. Instead, these decisions have tendcd to expand the area in which states may legislate." Id. at 73. The erroneous characterization of recent Supreme Court cases as instituting a balancing test is discussed supra Part II.C.3.

384. The third and final Indian decision Breyer wrote as a circuit judge shows a consciousness of the nature of tribal sovereignty, upholding a tribe's immunity from suit by interpreting the Rhode Island Indian Claims Act narrowly. See Narragansett Tribe v. Guilbert, 989 F.2d 484, 1993 U.S. App. LEXIS 6018, at*3-*4 (1st Cir. 1993) (unpublished table decision) ("[T] he Rhode Island Indian Claims Settlement Act subjected the Tribe's lands, but not the Tribe itself, 'to the civil and criminal laws and jurisdiction of the State of Rhode Island." ) (citation omitted).

385. See Supreme Court Confirmation Hearing for Judge Stephen G. Breyer: Hearing of the Senate Comm. on the Judiciary, 103d Cong., 2d Sess. (1994).

386. See id. 
Congress to abrogate treaties, but observed that it is the Court's task to enforce treaties in the absence of clear evidence of congressional intent to abrogate..$^{387}$ He showed sensitivity to the difficulty of jurisdiction cases involving "basic rights" of non-Indians while at the same time recognizing that "you have to respect very much the sovereignty of the tribe." 388 Breyer expressed a preference that such matters be "worked out through Congress" or in negotiations with tribes, which he referred to as sovereigns at several points. ${ }^{339}$ His other comments showed faith that tribal court procedures could be fair enough to remove non-Indian objections to tribal jurisdiction.

Most significant may be Breyer's 1995 dissenting opinion in Chickasaw, ${ }^{390}$ where he analyzed the treaty in question and found that it prevented state taxation of wages paid by the tribe to a tribal member who worked on the reservation but lived outside the reservation boundaries. ${ }^{391}$ In the treaty, the federal government had promised that no "State shall ever have a right to pass laws for the government of the [Chickasaw Nation] and their descendants; . . but the U.S. shall forever secure said [Chickasaw Nation] from, and against, all [such] laws. ${ }^{3392}$ Viewing the historical purpose of the treaty as protecting tribal government, he observed that the state tax "likely affects significantly and directly the way in which the Tribe conducts its affairs in areas subject to tribal jurisdiction. ${ }^{3993}$

Unlike Ginsburg, who wrote for the majority in Chickasaw, Breyer apparently recognized that the Court needed to look to Indian preemption principles, a task that entails parsing relevant treaties and laws. He did, however, suggest that the "well-established principles of tax law" generally would permit the state tax and that the treaty provided an exception. ${ }^{394}$ Unfortunately, Breyer failed to recognize the presumption against state taxation that is the beginning point of the analysis in Indian cases. $^{395}$

387. See id.

388. Id.

389. See id.

390. Okla. Tax Comm'n v. Chickasaw Nation, 115 S. Ct. 2214, 2225 (1995) (Breyer, J., dissenting).

391. See id. at 2225-26 (Breyer, J., dissenting)

392. Treaty of Dancing Rabbit Creek of 1830, Art. IV, 7 Stat. 333, 334, extended to Chickasaw Nation by Treaty of Jan. 17, 1837, Art. 1, 11 Stat. 573, quoted in Chickasaw, 115 S. Ct. at 2224-25.

393. Chickasaw, 115 S. Ct. at 2225 (Breyer, J., dissenting).

394. Id. at 2226.

395. See Montana v. Blackfeet Tribe of Indians, 471 U.S. 759, 765 (1985) ("[T] consistently has held that it will find the Indians' exemption from state taxes lifted only when Congress has made its intention to do so unmistakably clear."). Since Breyer construed the tax in Chickasaw as affecting on-reservation activities, the presumption allowing state law in absence of an express federal law to the contrary should not apply. See Mescalero Apache Tribe v. Jones, 411 U.S. 
There is no reason to assume that Breyer will fall into the subjectivist camp and there is some hope that he will make the effort to discover and apply foundation principles in Indian law.

\section{B. Content Versus Outcome}

Chief Justice Rehnquist and Justice Stevens, the senior members of the Court, are the two Justices who have shown special interest in Indian cases, writing large numbers of opinions. Stevens is the leader of the subjectivist camp and is willing to make policy choices in Indian jurisdiction cases with little more support than his perception of the "balance of interests." Rehnquist prefers to rely on historical perceptions and expectations concerning jurisdiction. However, both the available historical record, typically written by non-Indians, and his interpretation of it are essentially subjective and culturally skewed.

Indian sovereignty decisions by either Stevens or Rehnquist are almost certain to capture the votes of the other and of Justices Scalia, $\mathrm{O}^{\prime}$ Connor, Kennedy, and Thomas. They all have shown an inclination to vote for practical-sounding, plausible outcomes that are strongly influenced by the cultural values of non-Indians. More often than not, these Justices vote to rein in tribal sovereignty. It is reasonable to expect that they will continue to be motivated by subjective judgments about what the outcome "ought" to be. Thus, at least until one or more of them leaves, there is a strong, six-member subjectivist majority on the present Court.

Nonetheless, the existence of a subjectivist majority is not necessarily fatal to foundation principles. Only Justice Stevens appears to be so dedicated to the subjectivist view that he openly advocates in his opinions that the Court shape and balance policy considerations. The rest may be content to base their votes on traditional (or other) grounds so long as the rationale supports the desired outcome. Therefore, it may not always be necessary to command a majority as to the reasoning of a decision. If an outcome is supported by a majority, the writer can often attract a majority to join an opinion based on foundation principles.

Any hope that foundation principles can be resuscitated depends on the newer members of the Court-Justices Souter, Ginsberg, Breyer, and future appointees. To invoke these principles, they must take sufficient interest and at least one of them must assert intellectual leadership in Indian cases. If they understand that the Court's subjectivist misadventure is very recent and that the last decade's garbled precedent is really quite shallow, one or more of them could play a pivotal role in restoring Indian law to its 200 -year-old course. The new Justices could

145,148 (1973) (state taxation of activities carried on within a reservation is "not permissible absent congressional consent"). 
provide doctrinal consistency to the field if they began writing most of the decisions and applying foundation principles.

A knowledgeable expert on Indian law within the Court can be persuasive in drawing votes in close cases where subjective judgments are uncertain. Justice Thurgood Marshall became something of a specialist in Indian law, and his colleagues seemed glad for his leadership, content to let him perform an unpopular duty. ${ }^{396}$ They quibbled with his approaches from time to time, but he generally attracted majorities to his opinions. These majorities sometimes included reluctant brethren who concurred in an outcome supported by opinions that were thoughtful and well-rooted in precedent. If the junior Justices can revive the Marshall approach, they are likely to bring an often moderate "swing" voter, for instance Justice O'Connor, into their fold. Justice Scalia, too, may be susceptible to well-reasoned opinions based on foundation principles. If one accepts the reluctance of his concession to "the current state of affairs," ultimately he might be convinced that judicial subjectivism is not, after all, "too deeply imbedded in our jurisprudence to be changed, ${ }^{\prime 397}$ and he may gravitate to the more genuinely conservative foundational approach.

The prospect of the Court returning to the foundations of Indian law depends to a major extent, however, on the tenure of the Court's two oldest and longest-sitting members, Chief Justice Rehnquist and Justice Stevens. The background and interests of their successors, and the timing of their selection, will be critical.

The Chief Justice, of course, assigns opinions to be written by a member of the Court voting in the majority. Rehnquist's unease with tribalism, particularly as it affects non-Indians, could have special force if he chose to assign opinions to himself or Justice Stevens. So long as he sits, this practice could frustrate any attempt by newer Justices to take a leadership role in Indian cases. Since becoming Chief Justice, however, Rehnquist has shown little personal interest in writing Indian law opinions. 398

The lack of interest by most Justices besides Stevens may lead Rehnquist, like many of his predecessors, to assign Indian cases disproportionately to the junior members of the Court. If he has become less zealous in his desire to reshape doctrine in the field, perhaps he will do

396. Professor Tsosie has written that "Justice Marshall's opinions ... have largely defined the status of Indian nations in the modern era." Tsosie, supra note 295, at 496. See generally Robert Laurence, Thurgood Marshall's Indian Law Opinions, 27 How. L.J. 3 (1984) (reviewing 15 Marshall decisions from 1970-83).

397. Scalia has occasionally gone out of his way to recite the ideal of judicial separation from policy concerns in his dicta. See, e.g., County of Yakima v. Confederated Tribes \& Bands of Yakima Indian Nation, 502 U.S. 251, 265 (1992).

398. See supra text accompanying note 293. 
so even if the newer Justices are inclined to support their majority opinions with foundation principles. If Rehnquist (or the Justice appointed to replace him as Chief Justice upon his retirement) assigns Indian cases to Justices committed to returning the Court to a principled line of doctrine in the field, it could make a remarkable difference. The Court's subjectivist misadventures in Indian law may be historically cabined as aberrations, and the course of Indian law could resume its traditional course.

\section{CONCLUSION}

Bedrock principles of Indian law, applied continuously from the nation's founding until recently, left Indian country largely to tribal governance, except to the extent that Congress expressly extended federal or state jurisdiction or limited tribal powers. Supreme Court decisions have begun to depart from these foundation principles. Those decisions have been based essentially on the Justices' subjective judgments about how they ought to allocate sovereign authority over nonIndians in Indian country in order to avoid cultural clashes. This subjectivist approach has now attracted the majority of the present Court away from the weight of precedent in Indian law. Contrary to Justice Scalia's perception, confided to his colleagues shortly after he joined the Court, subjectivism is not "too deeply imbedded... to be changed," at least not yet. The Court probably could return to a foundational approach without significant overruling of recently created precedent. As more Indian decisions follow the subjectivist approach, however, it will become increasingly difficult to resurrect foundation principles. If so, Scalia's candid statement could prove prescient.

No one has yet emerged among the newer members of the Court, however, to carry forward the legacy of foundation principles of Indian law. There is some indication that leadership could come from Justice Souter, Justice Breyer, or possibly Justice Ginsburg. If sufficiently strong, this leadership could put Indian law back on track, albeit with majorities composed of Justices who are persuaded less by traditional rationales than by outcomes that satisfy their subjectivist notions of "what ought to be."

This Article criticizes the present, ostensibly conservative, Court for its subjectivism. The foundation principles of Indian law demand resistance to the temptation of judicial activism. A return to foundation principles, furthermore, would spare tribes the subjective judgments of courts by requiring congressional action, with the scrutiny of the political process and the tribes' full participation, before modifying their rights as sovereigns. Indian rights do not depend on sympathy for the plight or historical mistreatment of Native Americans. Self- 
determination for tribes is rooted in ancient laws and treaties, and is protected against incursions except those that Congress deliberately allows. Well-meaning judicial attempts to balance and accommodate interests of Indians and non-Indians not only are inconsisient with the limited role of courts, as sanctioned by the foundation principles of Indian law, but are inevitably culturally charged. It is always difficult for a governmental institution to inake a truly balanced and fair determination of the best interests of peoples from another culture. Therefore, when such decisions must be made they deserve the highest degree of deliberation, public scrutiny, and clarity available in the political system. That is why the Court, which deals with Indian cases only in fact-specific contexts and without political accountability, should yield to the political branches. 


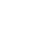

